UNIVERSIDADE DE BRASILIA

INSTITUTO DE ARTES

DEPARTAMENTO DE ARTES VISUAIS

Ana Heloiza Braga Lima Albano

Arte social na obra de Renina Katz:

uma análise de Antologia Gráfica 


\section{Arte social na obra de Renina Katz: uma análise de Antologia Gráfica}

Monografia apresentada como requisito parcial à obtenção do título de bacharel em Teoria, Crítica e História da Arte pela Universidade de Brasília.

Orientadora: Prof. ${ }^{\text {a }}$ Dr. ${ }^{\text {a }}$ Maria do Carmo Couto da Silva. 


\section{ANA HELOIZA BRAGA LIMA ALBANO}

\section{Arte social na obra de Renina Katz: \\ uma análise de Antologia Gráfica}

Monografia aprovada como requisito parcial para obtenção do título de bacharel em Teoria, Crítica e História da Arte pela Universidade de Brasília.

Aprovada em:

Banca Examinadora

Prof. ${ }^{a}$ Dr. ${ }^{a}$ Maria do Carmo Couto da Silva

Prof. ${ }^{\mathrm{a}}$ Dr. ${ }^{\mathrm{a}}$ Cristina Antonioevna Dunaeva

Prof. Ms. Gregório Soares Rodrigues de Oliveira 
Para minha neta, Sofia. 


\section{AGRADECIMENTOS}

No final do meu curso, após um longo aprendizado e tomada de consciência histórica e teórica, eu tinha uma certeza sobre o meu trabalho de conclusão do curso: desejava imensamente escrever sobre um artista brasileiro, em especial uma artista mulher, cuja linguagem fosse a gravura. Fiquei deslumbrada com a gravura, por sua riqueza de detalhes e sua intimidade com as narrativas. Tudo isso me fazia voltar o olhar para essas produções. Primeiro foi Honoré Daumier, em seguida Goya, Rembrandt, William Blake, Lasar Segall, Lívio Abramo, J. Borges, Samico, enfim, muitos outros surgiram e ressurgiram.

Chegou a hora e teria que decidir o tema do meu trabalho. Logo surgiu a caríssima professora e orientadora Maria do Carmo Couto da Silva, a quem agora agradeço imensamente por compartilhar os seus conhecimentos comigo. Agradeço, também, à Universidade de Brasília, por me proporcionar um vasto conhecimento sobre a História da Arte e, particularmente, por me apresentar a obra de Renina Katz, artista brasileira, gravurista e mulher, com um intenso trabalho voltado para o realismo social nacional. Obrigada, Maria, pelo carinho que sempre esteve presente no nosso convívio, pela sua dedicação e respeito no trato e, acima de tudo, por compartilhar comigo o seu conhecimento científico. Você me contagiou ainda mais com a sua vibração e paixão pela arte moderna brasileira. Na ocasião da primeira disciplina cursada com você, percebi que realmente era sobre esse tema que deveria me dedicar nos próximos semestres.

Agradeço, também, à equipe do Itaú Cultural: Victor Soriano, da Educação e Relacionamento; Renata Silveira e Jonathan de Brito Faria, da Memória e Pesquisa; e especialmente, Angélica Pompílio de Oliveira, do Acervo de Obras de Arte, que foi quem me proporcionou o primeiro encontro com a obra Antologia Gráfica. Ela teria ido pegar a obra no Jabaquara. Foi um dos momentos mais emocionantes na minha pesquisa. Naquele momento, fiquei tomada de emoção e deslumbramento.

Agradeço ao Centro de Documentação e Memória da Pinacoteca de São Paulo, nas pessoas de Isabel Cristina Ayres da Silva Maringelli, Diego Silva, Larissa Alves e especialmente Leandro Antunes Araújo, que me acolheu e pôs à minha disposição o riquíssimo dossiê sobre a artista que havia na instituição.

Ao Centro de Pesquisa do Museu de Arte Moderna de São Paulo, agradeço a Bruno Cezar Mesquita Esteves, que, com sua excepcional dedicação e acolhimento, me apresentou o organizado e extenso dossiê da artista. 
Agradeço, também, à Fundação Armando Álvares Penteado a dedicação e cordialidade das funcionárias da Coordenação de Curadoria e Acervo do Museu de Arte Brasileira, Fernanda Celidonio e Ana Carolina Boaventura. Em especial, agradeço à Laura Suzana Rodríguez, que me recebeu e proporcionou acesso às imagens por meio físico e eletrônico.

À minha família, obrigada pelos momentos que vivemos juntos e por me incentivarem durante toda a graduação e, neste momento especial, por me apoiarem na conclusão do curso dos meus sonhos. 


\section{RESUMO}

Antologia Gráfica é um álbum-obra resultado do processo criativo de Renina Katz durante os anos de 1948 a 1956. Representa uma seleção de xilogravuras e linoleogravuras que retratam o homem trabalhador brasileiro e retirante em contexto de precariedade, miséria, fome e incertezas. A artista busca inspiração no realismo social e no expressionismo para construir sua poética e faz reverberar os temas sociais muito presentes naquela época. Katz responde aos apelos dos estudiosos da história da arte nacional para a necessidade de se produzir mensagem social na produção artística. A obra tem como ponto central a representação do homem, das mulheres e das crianças em suas relações espaciais com os campos de trabalho, as atividades diárias da favela e as ruas das grandes cidades. Podemos visualizar também, nessa obra, gravuras desvinculadas da temática predominante e que refletem uma ligação da artista com narrativas nacionais e internacionais.

Palavras-chave: Renina Katz, gravura, arte social, Antologia Gráfica. 


\begin{abstract}
Antologia Gráfica is a compilation of the creative process of Renina Katz during the years of 1948 to 1956. It represents a selection of xylographs and linoleographs that portray the Brazilian migrant working man in a context of precariousness, misery, hunger and uncertainties. The artist seeks inspiration in social realism and expressionism to build her poetics and to reverberate the very present social issues at that time. Katz responds to the appeals of National History Art' scholars to the need to place a social message in the artistic production. The work focuses on the representation of man, women and children in their spatial relationships with workplaces, daily activities in the slums and the streets of large cities. We can also visualize, in this work, engravings unrelated to the predominant theme and that reflect connection of the artist with national and international narratives.
\end{abstract}

Keywords: Renina Katz, engraving, social art, Antologia Gráfica. 


\section{SUMÁRIO}

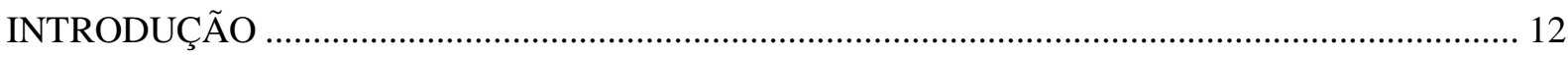

CAPÍTULO 1 - GRAVURA E REPRESENTAÇÕES SOCIAIS NO BRASIL ................................. 17

1.1 A arte e representação social no Brasil, na América Latina .......................................................... 20

CAPÍTULO 2 - RENINA KATZ E SUA TRAJETÓRIA ARTÍSTICA …............................................. 31

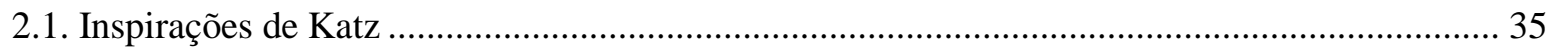

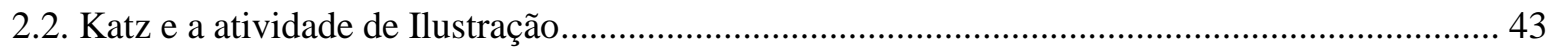

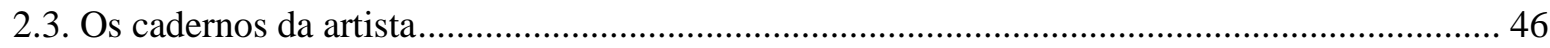

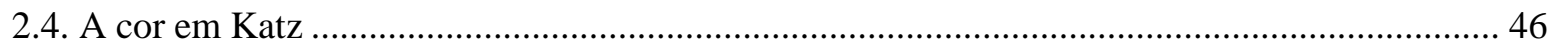

CAPÍTULO 3 - ANTOLOGIA GRÁFICA: UM OLHAR SOBRE A GRAVURA DE RENINA KATZ

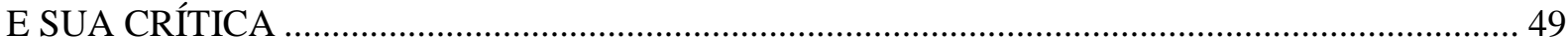

3.1. Temas das gravuras: uma representação da sociedade ................................................................ 55

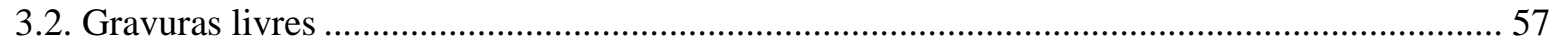

3.3. A série de gravuras de trabalhadores do campo e atividades econômicas .................................. 61

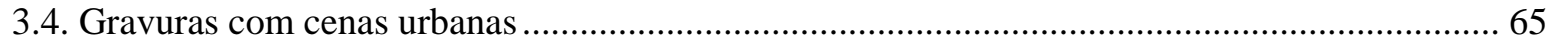

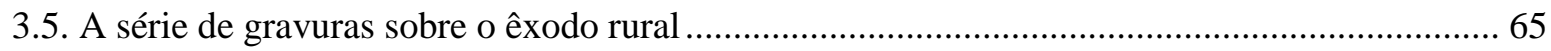

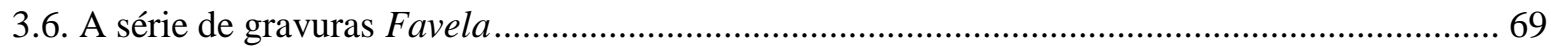

3.7. Considerações gerais e diálogos entre outras obras e as gravuras da Antologia Gráfica........... 72

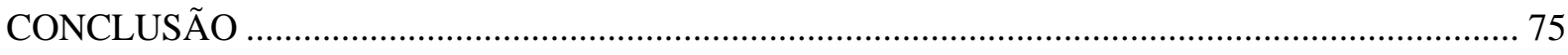

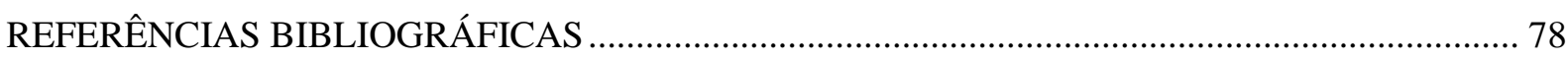




\section{LISTA DE FIGURAS}

Figura 1 - Tarsila do Amaral, Operários, 1933, óleo sobre tela, Acervo artístico-cultural dos Palácios do Governo do Estado de São Paulo.

Figura 2 - Renina Katz, Salinas, 1948-1956, xilogravura, Fundação Armando Alvares Penteado, ..... 25 Figura 3 - Tarsila do Amaral, Segunda classe, 1933, óleo sobre tela, Coleção particular, São Paulo. . 25 Figura 4 - Renina Katz, Retirantes, 1948-1956, xilogravura, Fundação Armando Alvares Penteado,. 26 Figura 5 - Renina Katz, Retirantes, 1948-1956, xilogravura, Fundação Armando Alvares Penteado,. 26 Figura 6 - Honoré Daumier, O Vagão de Terceira Classe, 1862, óleo sobre tela, Galeria Nacional do Canadá, Ottawa, 65,4 x 90,2 cm.

Figura 7 - Käthe Kollwitz, A Marcha dos Tecelões, 1897, gravura em água-forte, 21,6x 29,5 cm...... 37

Figura 8 - Renina Katz, Retirantes, 1948-1956, gravura, Fundação Armando Alvares Penteado, São Paulo, $15,8 \times 28,7 \mathrm{~cm}$.

Figura 9 - Renina Katz, Retirantes, 1948-1956, gravura, Fundação Armando Alvares Penteado, São Paulo, $18,2 \times 15,9 \mathrm{~cm}$.

Figura 10 - Käthe Kollwitz, Fome, 1924, carvão vegetal, 35 x $50 \mathrm{~cm}$ 39

Figura 11 - Renina Katz, Cidade, 1948-1956, gravura, Fundação Armando Alvares Penteado, São Paulo, 28,2 x $20.2 \mathrm{~cm}$. 40

Figura 12 - Renina Katz, Cidade, 1948-1956, gravura, Fundação Armando Alvares Penteado, São Paulo, 29,6 x 18,5 cm. 40

Figura 13 - Piet Mondrian, A árvore vermelha,1909/1910, óleo sobre tela, 70 x $99 \mathrm{~cm}$,

Gemeentemuseum, Haia, Holanda.

Figura 14 - Piet Mondrian, A árvore cinzenta, 1911, óleo sobre tela, 78,50 × 107,5 cm, Museu Municipal de Haia.

Figura 15 - Piet Mondrian, Macieira em flor, 1912. Óleo sobre tela, $78 \times 106 \mathrm{~cm}$, Gemeentemuseum, Haia, Holanda....

Figura 16 - Renina Katz, Cárceres, 1979, litogravura a cores, Museu Nacional de Belas Artes, Rio de Janeiro, 52 x $34 \mathrm{~cm}$.

Figura 17 - Renina Katz, Cárceres, 1979, litografia a cores, Museu Nacional de Belas Artes, Rio de Janeiro, 50,8 x 33,8 cm.

Figura 18 - Renina Katz, O Romanceiro da Inconfidência, 1953, Ilustração para capa de livro, Centro de Documentação da Estação Pinacoteca, São Paulo.

Figura 19 - Renina Katz, Antologia Gráfica, 1948-1956, xilogravuras e linoleogravuras, Fundação

Armando Álvares Penteado, São Paulo 50

Figura 20 - Renina Katz, Retirantes, 1948-1956, xilogravura, Fundação Armando Álvares Penteado,

São Paulo, 17,3 x $22 \mathrm{~cm}$.

Figura 21 - Renina Katz, Retirantes, 1948-1956, xilogravura, Fundação Armando Álvares Penteado, São Paulo, 17,6 x 22,6 cm. 53

Figura 22 - Renina Katz, Favela, 1948-1956, xilogravura, Fundação Armando Álvares Penteado, São Paulo, 28,2 x 19,7 cm.

Figura 23 - Renina Katz, Retirantes, 1948-1956, xilogravura, Fundação Armando Álvares Penteado,

São Paulo, 19,6 x 13,6 cm. 55

Figura 24 - Renina Katz, Retirantes, 1948-1956, xilogravura, Fundação Armando Álvares Penteado, São Paulo, 17,4 x 13,2 cm.

Figura 25 - Renina Katz, Florista, 1948-1956, xilogravura, Fundação Armando Álvares Penteado, São Paulo, 31 x 21,5 cm. 
Figura 26 - Renina Katz, Quintal, 1948-1956, xilogravura, Fundação Armando Álvares Penteado, São Paulo, $17,2 \times 27,2 \mathrm{~cm}$.

Figura 27 - Renina Katz, Morte no Laranjal, 1948-1956, linóleogravura, Fundação Armando Álvares

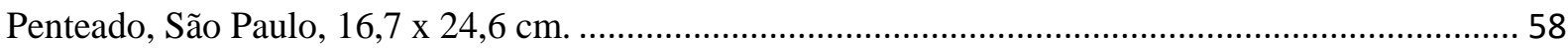

Figura 28 - Käthe Kollwitz, Estupro, gravura em água-forte e verniz mole, 30.8 x $52.8 \mathrm{~cm}, 1907 \ldots . .58$

Figura 29 - Renina Katz, Zé, 1948-1956, xilogravura, Fundação Armando Álvares Penteado, São

Paulo, 11,2 x 9,8 cm 59

Figura 30 - Renina Katz, Mulata, 1948-1956, xilogravura, Fundação Armando Álvares Penteado, São

Paulo, 17 x 12,9 cm.

Figura 31 - Renina Katz, Pau de sebo, 1948-1956, xilogravura, Fundação Armando Álvares Penteado,

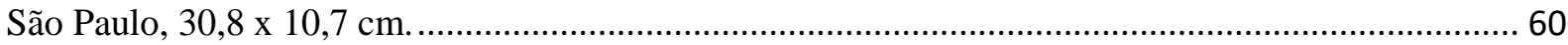

Figura 32 - Cândido Portinari, Futebol, 1935, óleo sobre tela, Coleção Particular, 97 x 1,30 cm........ 60

Figura 33 - Cândido Portinari, Menino com estilingue, 1947, óleo sobre tela, 59,5 cm x $103 \mathrm{~cm}$....... 60

Figura 34 - Renina Katz, Camponesas, 1948-1956, xilogravura, Fundação Armando Álvares Penteado,

São Paulo, 19,3 x 16,8 cm....

Figura 35 - Jean-François Millet, As respigadeiras, 1857, óleo sobre tela, 83, 8 x $111 \mathrm{~cm}$, Museu

D’Orsay, Paris.

Figura 36 - Renina Katz, Camponesas, 1948-1956, xilogravura, Fundação Armando Álvares Penteado, São Paulo, 18,7 x 30,9 cm.

Figura 37 - Renina Katz, Pescadores, 1948-1956, xilogravura, Fundação Armando Álvares Penteado,

São Paulo, 19 x $23,7 \mathrm{~cm}$. 63

Figura 38 - Renina Katz, Barqueiro, 1948-1956, xilogravura, Fundação Armando Álvares Penteado, São Paulo, 17,7 x 22,7 cm.

Figura 39 - Renina Katz, Trabalhadores, 1948-1956, xilogravura, Fundação Armando Álvares

Penteado, São Paulo, 16,2 x $30 \mathrm{~cm}$.

Figura 40 - Renina Katz, Trabalhadores, 1948-1956, xilogravura, Fundação Armando Álvares

Penteado, São Paulo, 22,3 x 30, 6 cm.

Figura 41 - Renina Katz, Campo, 1948-1956, xilogravura, Fundação Armando Álvares Penteado, São

Paulo, $19,3 \times 28,7 \mathrm{~cm}$. 65

Figura 42 - Renina Katz, Retirantes, 1948-1956, xilogravura, Fundação Armando Álvares Penteado, São Paulo, 15,8 x 28,7 cm.

Figura 43 - Cândido Portinari, Café, 1935, óleo sobre tela, Acervo do Museu Nacional de Belas Artes,

Rio de Janeiro, $1,30 \mathrm{~cm} \times 1,95 \mathrm{~cm}$. 66

Figura 44 - Renina Katz, Retirantes, 1948-1956, xilogravura, Fundação Armando Álvares Penteado,

São Paulo, 19,2 x 17,8 cm. 67

Figura 45 - Renina Katz, Retirantes, 1948-1956, xilogravura, Fundação Armando Álvares Penteado, São Paulo, 17,4 x 13,2 cm. 67

Figura 46 - Renina Katz, Retirantes, 1948-1956, xilogravura, Fundação Armando Álvares Penteado, São Paulo, 18,2 x 15,9 cm. 68

Figura 47 - Renina Katz, Favela, 1948-1956, xilogravura, Fundação Armando Álvares Penteado, São Paulo, $34,8 \times 25,3 \mathrm{~cm}$.

Figura 48 - Renina Katz, Favela, 1948-1956, xilogravura, Fundação Armando Álvares Penteado, São Paulo, 23,3 x 16,6 cm.

Figura 49 - Tarsila do Amaral, Morro da favela, 1924, óleo sobre tela, Coleção Hecilda e Sérgio

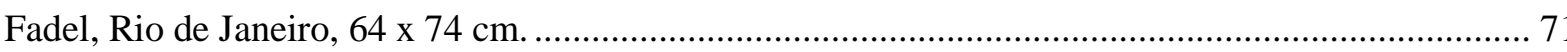

Figura 50 - Glênio Bianchetti, Pequena Olaria, linoleogravura de 1951, Itaú Cultural, ....................... 73 


\section{INTRODUÇÃO}

Procurarei analisar a arte de temática social no Brasil por meio do estudo de xilogravuras e linoleogravuras produzidas por Renina Katz e que foram selecionadas para compor o magnífico livro-obra Antologia Gráfica. Este álbum contém 45 gravuras confeccionadas pela artista nos anos de 1948 a 1956, impressas em papel colorido e às vezes por linhas também coloridas e/ou em preto e branco.

Este período no Brasil foi marcado por intenso movimento migratório procedente de várias partes do país e especificamente das áreas rurais do nordeste brasileiro, onde havia o enfrentamento de uma seca sem igual. O Estado não ofereceu alternativas governamentais para que ocorresse a fixação do homem em suas terras, como infraestrutura e água, assim famílias inteiras partiram em busca de novas oportunidades, apesar do futuro incerto que as aguardavam. Esse movimento favoreceu o desenvolvimento das grandes cidades brasileiras, com o fornecimento de mão de obra. Renina Katz capta as imagens da chegada dos retirantes e as grava especialmente através da xilogravura. Antologia Gráfica é, dessa forma, além de uma obra de arte, um documento visual em que a artista construiu a sua denúncia social por meio de imagens sobre estes movimentos: os retirantes; o cotidiano dos trabalhadores; a vida das mulheres e das crianças nas favelas, nas ruas das grandes cidades; e o universo dos camponeses. A temática sobre o trabalho foi muito explorada pela arte social brasileira para representar a relação entre proprietário e empregado.

O período estudado foi caracterizado pelo debate iniciado na França, através de uma pesquisa de Commune sobre a pintura e sobre a função e a socialização da arte, ou seja, a necessidade de a arte transmitir uma mensagem acerca das relações do homem no meio social, suscitar reflexões e transformar a vida em sociedade. No Brasil, na América Latina e na Europa, o cenário era o mesmo em torno dessa questão. O ambiente da arte vivia uma revisão na sua poética, cada um ao seu modo, construindo os seus discursos em busca de linguagens efetivas para atender o novo projeto de combate às injustiças sociais por meio de uma proximidade com o povo (AMARAL, 1984, p. 18-19 e 51).

No Brasil, na década de 1940, surge um grupo de jovens paulistas que se voltou para o expressionismo como convenção artística e plástica. Esses artistas, provavelmente como ocorrera com Lívio Abramo, haviam sido tocados pela obra de Käthe Kollwitz e pelas referências bibliográficas sobre arte moderna na Seção de Arte da Biblioteca Municipal de São Paulo. Esses jovens artistas mostravam certa resistência à abstração, que era uma tendência crescente no mundo do pós-guerra, inclusive no Brasil (SIMONE, 2004, p. 192-197). 
Durante sua atuação como militante de esquerda, Katz foi bastante ativa: promoveu debates, sessões de documentários sobre Velázquez e Daumier, entre outras atividades (BECCARI, 1981). A artista afirma que esteve próxima do expressionismo alemão e de trabalhos de mexicanos como Posada e Leopoldo Mendez, o qual fundou o Taller de Artes Gráficas, que é considerado o centro da tradição expressionista latino-americana. Este centro de produção artística influenciou a criação do Clube de Gravura de Porto Alegre. Todos esses aspectos foram abordados por Renina Katz em entrevista realizada por Vera D'Horta Beccari e publicada no jornal $O$ Estado de São Paulo do dia 4 de outubro de 1981.

A artista manteve-se engajada junto à proposta de Carlos Scliar, que fundara o Clube da Gravura em Porto Alegre, onde defendiam claramente o processo de militância social. Lá eram frequentes as conferências e os debates sobre a arte e a sua mensagem social. Tarsila do Amaral e Caio Prado Júnior participaram desses debates. Os temas como a miséria, a pobreza, a má distribuição de riqueza e a relação entre empregador e empregado foram trabalhados também por outros artistas expressionistas e do realismo social (SIMONE, 2004, p 185).

A preocupação social na arte reverberou tardiamente na América do Sul, pois somente a partir da década de 20 surge como interesse para o meio intelectual e artístico. Nesse período, em decorrência de fatores históricos, predominava no Brasil uma busca pelo nacionalismo (AMARAL, 1984, p. 18).

Katz afirma em entrevista a Leonor Amarante que no seu engajamento social havia uma discussão complicada sobre o socialismo soviético e as artes. Os princípios básicos nesses debates ocorriam de forma sectária e divergiam da poética de Katz (Cf. AMARANTE, in KATZ, 1997, p. 19-20).

Por meio da obra de Aracy Amaral (1984), que trata sobre a preocupação social da arte brasileira nos anos de 1930 a 1970, Katz comenta o sectarismo em São Paulo e afirma que os artistas infelizmente ainda viviam sob o efeito de influências políticas externas, como se vivessem o colonialismo sobre a arte. Esse controle externo ocorreu no sentido de dar à arte um enfoque panfletário, de controle social conforme as ideias do Zhdanovismo ${ }^{1}$, situação que a artista considerava muito decadente (AMARAL, 1984, p. 163).

\footnotetext{
${ }^{1}$ Em 1934, o realismo socialista se tornou a doutrina estética oficial do Partido Comunista da União Soviética pelas mãos de Andrei Zhdanov, o primeiro secretário do Comitê Central do Partido durante o I Congresso dos Escritores. O artista realista socialista da linha zhdanovista deveria trabalhar com a figuração, em imagens de conteúdo facilmente apreendido, um realismo praticamente desprovido de crítica e que mais se aproximasse de um romantismo revolucionário (DUPRAT, 2013, p.748).
} 
A temática do realismo social predominou por dez anos no trabalho da artista, período no qual produziu Favela, Retirantes, Trabalhadores, Camponesas, Camponeses e outras gravuras relacionadas aos temas sociais - todas elas estão presentes em Antologia Gráfica.

Katz e outros artistas comprometidos com a arte social no Brasil buscaram tanto a associação temática como também as características da linguagem expressiva dos modelos de Käthe Kollwitz, cujo centro de atenção se voltava para os aspectos humanos, por meio das imagens de mulheres com crianças, trabalhadores ilustrados como heróis e outras situações passíveis de denúncia (SIMONE, 2004, p. 185- 200).

Nas referências estudadas para este trabalho, é comum verificar que a Antologia Gráfica se relaciona com o realismo social e que ela contribui, por meio dos registros gráficos, para o entendimento sobre um período da história brasileira. Outro fator que despertou interesse em minha pesquisa foi o fato de a obra ter sido pouco estudada e, portanto, requerer um maior conhecimento sobre a sua existência e sua construção, em que podemos perceber os pressupostos e as convenções que a deram sentido. Por meio da obra, podemos verificar a composição formal e social vigente neste período e, assim, situar o processo criativo da artista na história da arte.

Esta monografia foi organizada em três capítulos, cujos conteúdos serão expostos a seguir:

No primeiro capítulo, descrevo alguns aspectos sobre a história da gravura voltada para o realismo social e a situo no contexto sócio-político no qual vivia o Brasil e a América Latina como reflexo do cenário artístico e político pós Segunda Guerra Mundial.

Ainda nesse capítulo, explico que havia uma preocupação em retratar os aspectos sociais no Brasil e no México. Artistas brasileiros, mexicanos e outros saíram em busca de novas linguagens, de seus tipos e temas nacionais capazes de atender ao apelo por uma arte voltada para a coletividade. Katz seguiu a linguagem da gravura e ilustrou o homem, a mulher e as crianças inseridas na favela, no trabalho, nos campos, se deslocando, nas ruas das grandes cidades em condições precárias.

No segundo capítulo, discorri sobre a trajetória da artista e as suas inspirações. Katz olhou para a produção de Käthe Kollwitz e reconhece que o seu interesse pela arte social se intensificou. As gravuras de Antologia Gráfica representam na produção de Katz um período sob esse olhar em torno da obra da artista alemã. Além disso, marcaram sua formação em gravura os ensinamentos recebidos de Leskoschek e Carlos Oswald. Sua formação acadêmica ocorreu na Escola Nacional de Belas Artes do Rio de Janeiro. 
Traço, também, considerações acerca da sua experiência como docente na Universidade de São Paulo e da sua habilidade e conhecimento técnico sobre gravura, o que a permitiu desenvolver a atividade de ilustração de livros e jornais. Assim, pude perceber a sua ampla participação e importância para a história da arte e da gravura no Brasil. Durante os anos de 1948 a 1956, Katz definiu como linguagem a xilogravura, voltou-se para os temas sociais e realizou uma produção artística significante para a história da arte brasileira. Antologia Gráfica é um testemunho da riqueza de imagens e da qualidade estética da gravura no Brasil.

Nesse capítulo, procurei ainda elaborar conexões com outros artistas nacionais e internacionais que trabalharam com temas da representação social. Encontrei um diálogo entre as obras de Renina Katz e algumas de Tarsila do Amaral e Honoré Daumier. Abordei também a relação entre a obra da artista e o contexto social e político brasileiro por meio das suas figuras recorrentes em que predomina a temática social.

Pude perceber nas gravuras Cidade de Katz como ela já estava se iniciando na abstração, embora fizesse parte da minoria resistente à onda internacional dos abstracionismos. Katz, ao modo da árvore de Piet Mondrian, representa a sua cidade com leves apagamentos da figuração e sugere algumas formas que somente são acionadas pelas nossas memórias.

Constatei que, na produção da artista, há com frequência uma atuação junto às narrativas, como as ilustrações realizadas para o livro Romanceiro da Inconfidência de Cecília Meireles no ano de 1956, para O Vermelho e o Negro de Stendhal e outras ilustrações para jornais (Cf. AMARANTE, in KATZ, 1997, p. 32-34/74).

No terceiro capítulo, tracei considerações sobre as influências e possíveis diálogos entre algumas gravuras presentes em Antologia Gráfica de Katz e outras obras de Kollwitz, Leskoschek, Portinari, Tarsila do Amaral, Millet e outros artistas, que contemplam a temática social. Além disso, busquei estabelecer correlações entre fragmentos do prefácio de Flávio Motta e algumas gravuras de Katz. Em Antologia Gráfica, podemos verificar a importância do processo criativo da artista, que é visível através do aperfeiçoamento da técnica e do seu engajamento social e político.

No estudo dos aspectos formais sobre a obra gráfica de Katz, procurei correlacionar as gravuras que a compõe com aspectos históricos nacionais, como o imaginário social e a poética do realismo, entre outras questões. Nessa análise sobre Antologia Gráfica, faço considerações separadas sobre as séries Favela, Retirantes e Camponeses, além de outras xilogravuras e linóleo, que são gravuras mais livres da temática sobre o realismo social e que foram selecionadas também para compor a obra. Através de Antologia Gráfica, verificamos a riqueza 
de possíveis diálogos que as gravuras sociais da artista podem proporcionar com outras obras modernas. 


\section{CAPÍTULO 1 - GRAVURA E REPRESENTAÇÕES SOCIAIS NO BRASIL}

Consta na história da gravura do país, que havia uma proibição de utilizar a atividade gráfica no Brasil desde o século XVI. A atividade gráfica seria liberada somente com a chegada da corte portuguesa no ano de 1808. A partir desse período, a gravura passa a ser bastante produzida e a sua circulação torna-se dinâmica e eficiente. Dessa forma, a circulação das imagens também foi favorecida. Inicialmente, a atividade foi considerada clandestina e passível de penalidades para depois se tornar utilitária. Com o passar do tempo, veio a ser mais presente na primeira metade do século XIX, embora sem reconhecimento oficial.

Como meio artístico, na primeira metade do século XX, a xilogravura viveu seu apogeu. Este momento foi favorecido pelo fauvismo francês e pelo expressionismo alemão, que encontraram na xilogravura uma de suas principais formas de expressão. Esta linguagem acompanhou intensamente os artistas do fauve e do expressionismo. Houve certo interesse pela técnica por parte de alguns artistas do cubismo, do dadaísmo, do surrealismo e do construtivismo. Passou a ser de interesse individual como linguagem para a criação artística (Cf. MARTINS, in Gravura e Modernidade, 2016, p. 12-13).

Os primeiros gravadores nacionais situaram-se no Rio de Janeiro e em São Paulo, com exceção da xilogravura popular nordestina. Somente nos anos de 1950 a atividade se expandiu para outras localidades dentro do país. Renina Katz contribuiu com o seu trabalho para essa expansão nacional, através da sua obra e da formação de jovens seduzidos pela linguagem. A partir deste período, observamos a abertura de cursos, núcleos, clubes e grupos de gravura em várias partes do país. Tudo isso demonstra que a sociedade reconhecera a gravura como expressão artística e a legitima como arte (Ibidem, p. 14-16).

Carlos Scliar surge como integrante dos artistas figurativos da geração pós-guerra. Ele atua como um grande ponto de aglutinação sobre a gravura brasileira entre os artistas do sul, sudeste e nordeste. Em 1944, com o apoio desses jovens artistas, Scliar promoveu uma exposição no Rio de Janeiro, que, além dos artistas expressionistas, reuniu interessados pela arte de temática social e pela arte de denúncia de Käthe Kollwitz. Katz também fazia parte da geração interessada pelo expressionismo alemão e pelas representações sociais, fato que contribui para o entendimento da sua produção artística. Por meio das suas gravuras, ela aborda o contexto social dessa época e realiza uma denúncia sobre a situação de migração, êxodo rural, incertezas, fome, miséria, trabalho árduo e protestos, que foram algumas das suas temáticas nesse período (SIMONE, 2004, p. 200). 
O Clube da Gravura de Porto Alegre contribuiu intensamente com a história da gravura nacional juntamente a outras instituições e que, por apresentarem um envolvimento com a ideologia de esquerda, se direcionaram para o realismo social. Predominava sobre os artistas que comungavam dos ideais socialistas o interesse por uma temática simples, com predominância de tipos nacionais e que retratassem as situações sociais, econômicas e políticas mais urgentes (Cf. MARTINS, in Gravura e Modernidade, 2016, p. 15).

No Brasil, os anos de 1950 são pontuados como de intensa modernização e desenvolvimento, sob o comando de Juscelino Kubitschek que comungava dos ideais de industrialização e desenvolvimento do país de forma rápida e dinâmica. São Paulo se tornou a cidade símbolo da economia do país e desde os anos 1940 adere a este propósito de centro econômico. Além de estimular a produção industrial interna, participa inclusive do mercado exterior com a fabricação de artigos para exportação no pós-guerra (FERNANDES, 2007, p. 28).

Annateresa Fabris (2005, p. 79- 103), em Portinari e a arte social, chama a nossa atenção para o fato de como é possível "narrar uma história" livre de interesses estatais e apresentando uma visão crítica da sociedade contemporânea brasileira através da força de trabalho. Assim como fizera Portinari utilizando outra linguagem, Renina Katz também criou através de figurações de alguns segmentos da sociedade os seus camponeses em intensa atividade de trabalho. Utilizou linhas que transitaram no meio agrícola, em Salinas, em construção civil e em alto mar e representou o seu tipo nacional através da imagem do homem e da mulher trabalhadora. Fabris (2005) ressalta a ideia de que o pintor social deveria ir para as ruas, ocupar os espaços públicos com as suas obras capazes de comunicar-se com o povo.

Em Paris, no ano 1936, ocorreram debates sobre a relação da arte com a realidade do homem naquele momento e a sua capacidade de promover as mudanças sociais necessárias. Essas ideias foram publicadas sob o nome de querela do realismo. $\mathrm{O}$ movimento foi movido pela preocupação social e, como reação contrária ao estetismo, pregava uma arte acessível a todos (FABRIS, 2005, p. 24). Fernand Léger foi um dos defensores do realismo naquele momento. O realismo ao qual se referia era o que acabava com todo o sentimentalismo literário e descritivo para referendar a vida moderna através do capitalismo e da industrialização. A sua poética foi registrada através da utilização da cor, que para ele impulsionava a vida em todos os ângulos e reavivava todos os sentimentos. No início do século XX, a abstração, a ideia de originalidade e a desumanização são minimizadas pelas novas ideias que surgiram neste período (Ibidem, p. 79-82). 
A abstração em Katz ocorre no sentido da adesão à realidade do mundo concreto para as figurações fantásticas, para lentamente atingir a abstração, algumas líricas e outras surrealistas. A abstração de Katz nos sugere paisagens que no primeiro momento não são evidentes, mas se formam a partir de vestígios, restos, registros que são capazes de acionar as nossas memórias (Cf. PONTUAL, 1997, in. Renina Katz, Edusp, p. 73-74).

Já o discurso de André Lhote defendia a volta à representação sobre as questões humanas. Reconhecia em Cézanne o artista que representou o homem profundamente. A sua persistência formal e natural dos seres e das coisas, o domínio da técnica e visões do novo seria capaz de trazer a humanidade do artista para esse momento (Ibidem, p. 82).

No final dos anos de 1940, houve a formação de algumas iniciativas culturais institucionalizadas que também contribuíram para a história da arte no Brasil. Dentre essas iniciativas estão a criação do Museu de Arte de São Paulo Assis Chateaubriand (MASP) e a do Museu de Arte Moderna de São Paulo (MAM-SP) e outros eventos culturais voltados para o cinema e para o teatro. Logo, como podemos verificar, o ambiente encontrava-se favorável para a cultura (FERNANDES, 2007, p. 28).

Em 1956, Katz junto aos artistas, Mário Gruber, Luís Ventura, Virgínia Artigas e outros realizaram uma exposição no Sindicato dos Metalúrgicos de São Paulo. Nessa ocasião, aconteceu um fato curioso durante a mostra, pois o público presente na exposição não se identificou com aquelas imagens. Os artistas ofereceram ao público imagens do mundo operário mais sob a sua ótica do que sob a dos próprios trabalhadores. Portanto, havia um abismo enorme entre a visão do artista e a vida dos consumidores dessa arte. A situação possibilitou a Katz uma reflexão sobre a sua poética. Logo, Katz percebeu que se tornaria muito dogmática e não era este o seu propósito. Após uma autocrítica, ela resolveu mudar o seu percurso (BITTENCOURT, 2008, p. 25).

Nessa ocasião, Katz faz revisões ideológicas e percebe a necessidade de buscar novas experiências formais e poéticas. Mantendo-se lírica, partiu para uma relação com o mundo e com a natureza. Reiniciou as atividades do desenho a nanquim, a lápis de cor, a lápis de cera, ao mesmo tempo em que começaram a surgir atmosferas, paisagens e imagens menos literárias. Flávio Motta diz que Katz fez um percurso da busca das origens do mundo social para depois saltar ao cosmo, com o realismo mágico, transcendental e sem preocupação com o terreno (BECCARI, 1981, in Personagem da semana, Katz - O Estado de São Paulo). 


\subsection{A arte e representação social no Brasil, na América Latina}

O crítico de arte Mário Pedrosa regressou ao Brasil após estudos na antiga União Soviética em 1927 e filiou-se ao Partido Comunista Brasileiro em 1931. Posteriormente, afastou-se do partido por se identificar com a corrente trotskista. A sua palestra proferida no Clube de Arte Moderna sobre o tema Käthe Kollwitz e seu modo vermelho de perceber a vida são considerados o marco inicial de sua trajetória como crítico de arte. O seu discurso enfatizou como o trabalho de um povo reflete na sua produção artística. Defendeu também a necessidade de posicionamento político por parte dos artistas. Segundo o crítico, a arte social deveria contribuir para a transformação da realidade e aproximar-se da necessidade do povo, afastandose do individualismo burguês (DUPRAT, 2013, p. 748). Podemos verificar este pensamento de Mário Pedrosa sobre a arte social, transcrito abaixo e que fora publicado no periódico do Diário de São Paulo em 1933 no O Homem Livre² (SIMONE, 2004, p. 192):

A arte social (...) não é de fato um passatempo delicioso: é uma arma (...). a dialética da dinâmica social (...) faz com que uma obra desta, tão profundamente inspirada no amor e na fraternidade humana, sirva, entretanto, para alimentar o ódio de classe mais implacável. E com isso está realizada a sua generosa missão social (Ibidem, p. 192).

Dois anos depois, o Clube de Cultura Moderna realizou a primeira exposição de arte social, no qual predominaram as obras gráficas de Goeldi, Santa Rosa, Ismael Nery, Di Cavalcanti e Portinari. A tradição trazia o seu aspecto revolucionário por meio do desenho e da gravura de Honoré Daumier (1808-1879), Francisco de Goya (1746-1828) e Käthe Kollwitz. Esse evento foi bastante divulgado e as suas ideias logo se tornaram tema de debate no meio acadêmico (AMARAL, 1984, p. 50-51).

Em 1930, os trabalhos de Kollwitz, pelo seu estilo figurativo e pelos seus temas, se difundiram internacionalmente e foram tomados como modelo de arte revolucionária pelos socialistas e comunistas, inclusive no Brasil, onde ocorreram duas grandes exposições. As gravuras de Kollwitz circularam no sul do país, provavelmente trazidas pelos imigrantes europeus (SIMONE, 2006, p. 179-183).

Em 1934, o realismo socialista se tornou a convenção oficial do Partido Comunista da União Soviética por Andrei Zhdanov, que na época era o secretário do Comitê Central do Partido. O realismo socialista combatia a burguesia, a arte abstrata e subjetiva, acreditava que essa estava à parte da realidade e ainda ignorava o formalismo. $\mathrm{O}$ artista do realismo socialista

\footnotetext{
${ }^{2}$ O Homem Livre foi um semanário de política e cultura editado em São Paulo que reunia vários intelectuais trotskistas, anarquistas e socialistas, ou seja, todos os partidos proletários (AMARAL, 1984, p. 41).
} 
deveria apresentar imagens capazes de transmitir mensagens que promovessem um movimento revolucionário. Após 1945, com o início da Guerra Fria, os Estados Unidos intensificou a sua campanha anticomunista, que terminou por enfraquecer o Partido Comunista no Brasil (DUPRAT, 2013, p. 748-749). O realismo socialista atendia os princípios e defendia os interesses do partido socialista. A arte do realismo socialista deveria estar a serviço da ideologia das relações entre proletário e patrão e a arte deveria mostrar essa relação de modo romântico e revolucionário, as suas imagens deveriam ser fáceis de serem compreendidas e capazes de passar mensagens otimistas, sem qualquer evidencia crítica, assim atendia ao socialismo e defendia os interesses do partido socialista (Ibidem, 2013, p. 748).

No realismo social a arte se volta para as relações humanas e sociais em cenários do campo ou nas indústrias e nas grandes cidades. A arte do realismo social não estava a serviço de nenhum partido político, embora muitos artistas que dele participaram eram filiados ao partido comunista, mas a preocupação social estava acima de tudo (AMARAL, 1984, p. 3-13).

Aracy Amaral chama a nossa atenção para os pressupostos de Jean Franco quanto aos aspectos da arte social no mundo e especificamente sobre a América Latina. O estudioso afirma que na década de 1920 surge também, nos meios artísticos latino-americanos, um evidente anseio social. Este desejo, fonte de inspiração, foi estimulado pelo nacionalismo que permeava todos os países do mundo em decorrência da Revolução Russa de 1917, o que originou uma militância política e uma inquietação social. Estava evidente uma distância entre a poética dos artistas e o povo marginalizado. Os artistas que colocaram a sua produção à serviço da mensagem social partiram em busca desta nova forma, de uma linguagem na arte que melhor cumprisse os anseios e que possuísse um caráter universal para expressar esta vontade política contra a injustiça social decorrente das lutas contra a classe dominante (AMARAL, 1984, p. 18-19).

Segundo Jean Franco, o México viveu a sua revolução social e, em 1922, teve o muralismo como expressão artística capaz de influenciar toda a América Latina nos anos de 1930. Nesse período, surgem também muitos partidos políticos comunistas e socialistas. Esses partidos tinham a militância de artistas e intelectuais (Ibidem, 1984, p. 19).

Na América Latina, a arte social estava presente nas várias expressões artísticas, como nas artes plásticas, gráficas e literárias. No México, as gravuras de Posada de cunho político e panfletário tornavam o ambiente propício sobre a necessidade de uma maior conscientização social e política em que vivia a população nos anos de 1922 com a revolução social na qual houve a intervenção artística do Muralismo. Esse movimento se intensificou nos anos de 1930 
entre os artistas militantes. A militância na América Latina foi estimulada pela criação de partidos políticos comunistas e socialistas aos moldes de outros países no mundo, embora na América Latina houvesse uma grande diferença, pois as nossas expressões artísticas na pintura e na literatura estavam mais voltadas para os anseios da coletividade, enquanto na arte ocidental predominavam os temas existenciais e individuais (Ibidem p. 19-20).

Como consequência da revolução mexicana, surge no México uma tendência nativista que cresceu bastante durante as décadas de 1920 e 1930 e tinha como convenção a "redescoberta" e reavaliação das culturas e tradições nativas. Os temas retratados na literatura e artes visuais eram os indígenas e predominava o protesto social. Podemos citar desse período três obras que trazem a iconografia nativa, tratada de modos distintos, que às vezes estão submetidas parcialmente às políticas indianistas oficiais e, em outros momentos, estão livres da intervenção estatal. Essas obras que representam muito bem esse período no México são: $A$ Mãe Camponesa (1929) de Siqueiros, Dia de Flores (1925) de Diego Rivera e Varayoc: Chefe dos chincheros (1925) de José Sabogal. O nativismo no México surge como "atitude oficial voltada para o enaltecimento e promoção dos valores indígenas" - esta premissa é divulgada através do ensino nas escolas e universidades (ADES, 1997, p. 195-196).

Os artistas mexicanos desempenharam um importante papel na busca de uma arte social e política capaz de provocar mudanças significativas dentro na sociedade. Através dos trabalhos de Posada e Leopoldo Mendéz. A arte crítica e política de Posada teve uma abrangência significativa, pela manhã ele gravava e à tarde suas gravuras se encontravam espalhadas pela cidade. $\mathrm{O}$ artista utilizou as caveiras como elemento simbólico e atingiu o povo mexicano com as suas críticas políticas ácidas. Muitos artistas brasileiros se voltaram para esta forma de representação e buscaram ao seu modo as suas próprias representações e os meio para a divulgação dos seus trabalhos.

Os artistas latinos desejavam participar, com seus trabalhos, de uma mudança futura que marcasse novos tempos. Os muralistas mexicanos chamaram a atenção de outros latinos americanos ansiosos pelas mudanças. O México tornou-se atração também para os artistas do velho mundo, não apenas pelo muralismo, mas pelo contato e pelas trocas proporcionadas entre eles. Amaral (1984) afirma que, na América Latina, a questão política nem sempre surgia com a força e estéticas necessárias e suficientes para comunicar acerca de aspectos imprescindíveis para a arte do "realismo socialista" ou para a figuração (AMARAL, 1984, p. 18-19).

Muitos artistas brasileiros buscaram representar os aspectos sociais mais próximos, Lívio Abramo representou as longas jornadas de trabalho nas fábricas, Di Cavalcanti registrou 
as mulheres do mangue, Portinari pintou os trabalhadores das plantações de café e os retirantes, Tarsila do Amaral representou operários e mulheres em favela. Assim como Katz fez, representou a sociedade brasileira em situação de miséria e incerteza. Para atender a este discurso Katz voltou o seu olhar para o Expressionismo alemão do início do século XX, que significou um grande estímulo para a criação da gravura de denúncia social no Brasil. Além das diferenças entre os artistas brasileiros e os latinos, a assimilação sobre as características sociais da arte de Käthe Kollwitz e a divulgação dos seus trabalhos por escritores comunistas os aproximaram (SIMONE, 2004, p. 179).

No Brasil, a arte de militância política e social surgiu através dos clubes de gravura em 1933, através da primeira manifestação escrita sobre a problemática social do Brasil, assim como através da utilização da arte como estratégia para melhorá-la. Di Cavalcanti foi o primeiro artista plástico nacional a manifestar-se a favor da arte social. Na ocasião da exposição de Tarsila do Amaral no Rio de Janeiro em 1933, Di Cavalcanti, comovido pela revolução russa, teria convidado os artistas a participarem do processo revolucionário através das suas produções artísticas, conforme podemos visualizar abaixo (AMARAL, 1984, p. 33):

Nós artistas não podemos nos separar da humanidade, com "veleidade" possuímos qualquer coisa de superior aos nossos semelhantes. Por isso, quando um artista sente-se incompreendido não pode repudiar a incompreensão que o circula, deve ao contrário procurar as razões dessa incompreensão. E elas só poderão se encontrar no estado social que as determinam. Existe hoje no mundo uma divisão tão nítida de mentalidade, que o homem indiferente, o homem que se coloca acima das competições, tornou-se um anacronismo e toda sua existência é uma traição à sua época (Ibidem, p. 33).

$\mathrm{O}$ artista teria se inspirado em duas telas de Tarsila do Amaral, que apresentam a fase de interesse social, Operários (1933) e Segunda Classe (1933). A artista teria realizado a exposição dessas obras após o seu retorno da URSS. Outros artistas nessa época também estavam voltados para as questões que envolviam a arte social, como exemplo podemos citar Quirino Campofiorito e Eugênio Sigaud, com os temas sobre o operário (Ibidem, p. 33-34).

Tarsila do Amaral também proferiu palestra sobre a arte proletária e sobre a evolução do ideal de beleza nas artes e a sua capacidade de promover mudanças em uma sociedade revolucionária. Durante sua permanência na União Soviética, estudou pintura, além de pôsteres e artes gráficas. Como resultado desta experiência, a artista concluiu a obra Operários. Na obra podemos ver a apresentação de muitos protagonistas, que simbolizam a coletividade - uma 
preocupação comum nos ideais comunistas e a predominância de uma diversidade étnica e racial do Brasil presente nas características dos rostos de seus personagens.

A obra chama a nossa atenção para os movimentos imigratórios que ocorriam principalmente com destino a São Paulo no início do século XX, possível de verificar pela presença de muitas chaminés das indústrias. Outra obra produzida por Amaral acerca do realismo social foi Segunda Classe, obra crítica sobre a sociedade brasileira da época. Retrata a chegada de muitas famílias nordestinas também a São Paulo nos anos de 1930 em decorrência do êxodo rural e principalmente pela necessidade de força de trabalho para as indústrias e na produção do café. Incertezas e coragens são destacadas como sentimentos predominantes na obra (SIMONE, 2016, p. 185).

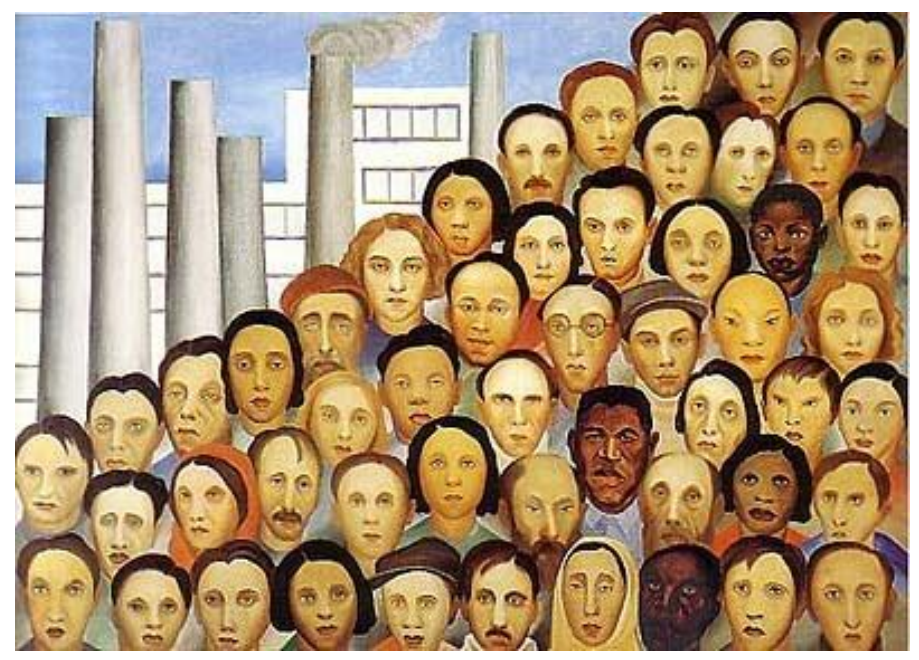

Figura 1 - Tarsila do Amaral, Operários, 1933, óleo sobre tela, Acervo artístico-cultural dos Palácios do Governo do Estado de São Paulo.

Os operários de Tarsila do Amaral trabalham na indústria, o que se pode constatar devido às chaminés que se pronunciam na obra acima, enquanto os de Katz são os da atividade agrícola, da construção civil e das atividades extrativas que predominavam na época, conforme se pode ver na imagem abaixo. 


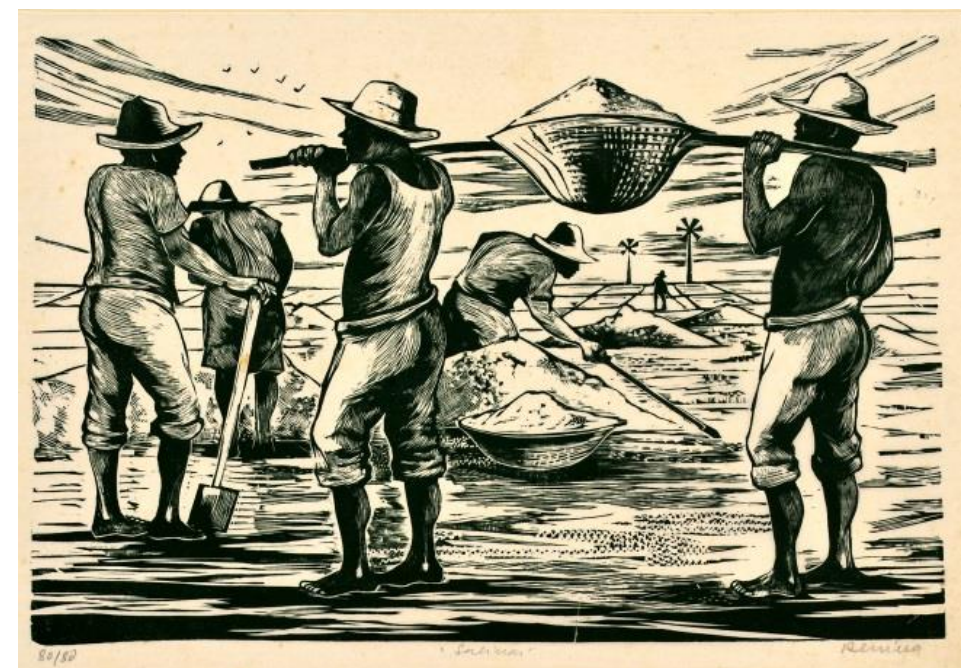

Figura 2 - Renina Katz, Salinas, 1948-1956, xilogravura, Fundação Armando Alvares Penteado, $24,1 \times 34,5 \mathrm{~cm}$.

Katz também retrata os aspectos citados por Tarsila do Amaral em sua obra Segunda Classe por meio das suas gravuras da série os Retirantes. Nesta série de Katz, podemos visualizar pessoas em transporte coletivo e popular acessível às classes mais desfavorecidas, como o pau de arara, que era utilizado pelos migrantes para se locomover de uma região a outra em longas distâncias. Em Retirantes não há necessidade de legenda para provocarmos os sentimentos de precariedade e incerteza sobre o que espera os imigrantes nas grandes cidades. Os diálogos possíveis entre essas obras podem ser visualizados nas imagens a seguir:

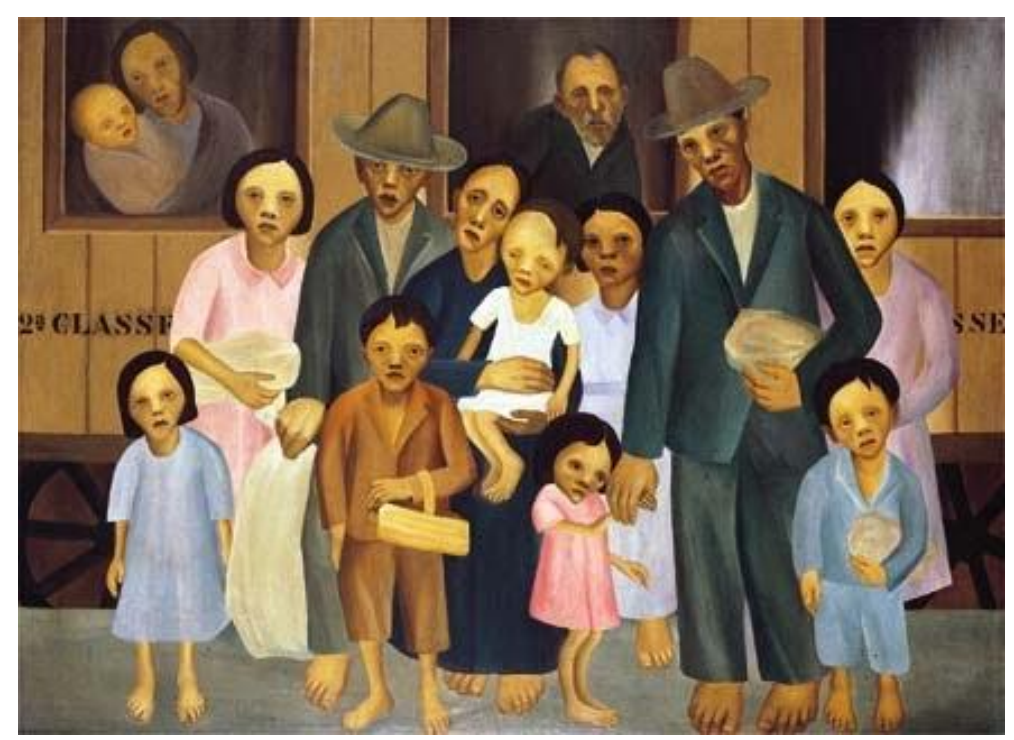

Figura 3 - Tarsila do Amaral, Segunda classe, 1933, óleo sobre tela, Coleção particular, São Paulo. 


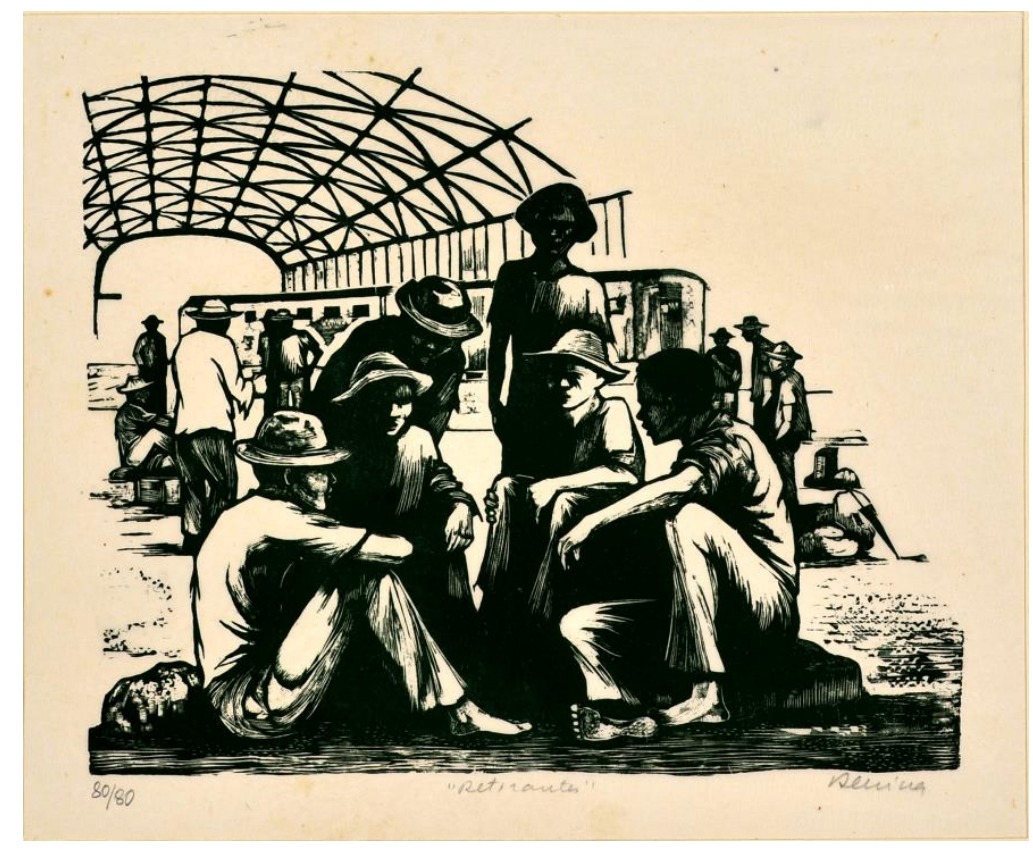

Figura 4 - Renina Katz, Retirantes, 1948-1956, xilogravura, Fundação Armando Alvares Penteado, $22,6 \times 27,5 \mathrm{~cm}$.

$\mathrm{Na}$ imagem acima, podemos verificar estações de trem onde a artista retratou um trem e uma estrutura de ferro imensa simbolizando uma estação. Ao fundo podemos ver homens chegando e outros sentados em volta com os seus pertences. $\mathrm{Na}$ imagem abaixo, Katz representou o transporte dos Retirantes por meio de carrocerias de caminhões, que eram utilizadas como transportes coletivos. Transportavam os retirantes que vinham do Nordeste para as grandes cidades do país em busca de oportunidades.

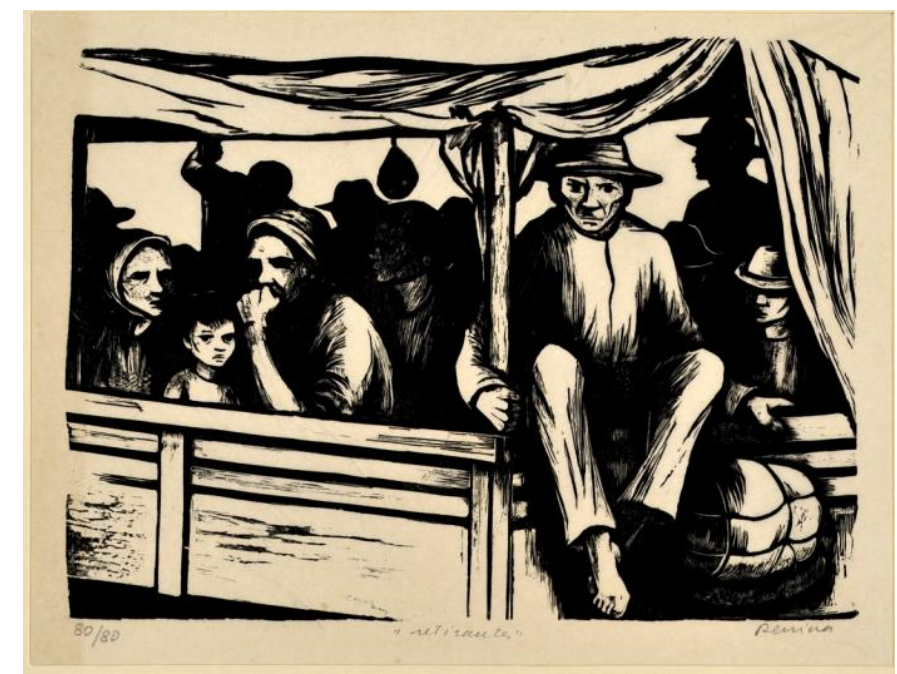

Figura 5 - Renina Katz, Retirantes, 1948-1956, xilogravura, Fundação Armando Alvares Penteado, $21,6 \times 28,5 \mathrm{~cm}$.

Os Retirantes de Katz dialogam com Segunda Classe de Tarsila do Amaral e com Honoré Daumier através da representação de $O$ Vagão de terceira classe (1862), momento no 
qual o artista também denuncia a pobreza existente na época. Em Honoré Daumier no primeiro plano, as condições da família são retratadas com simplicidade e nobreza, expressão de aceitação e fadiga.

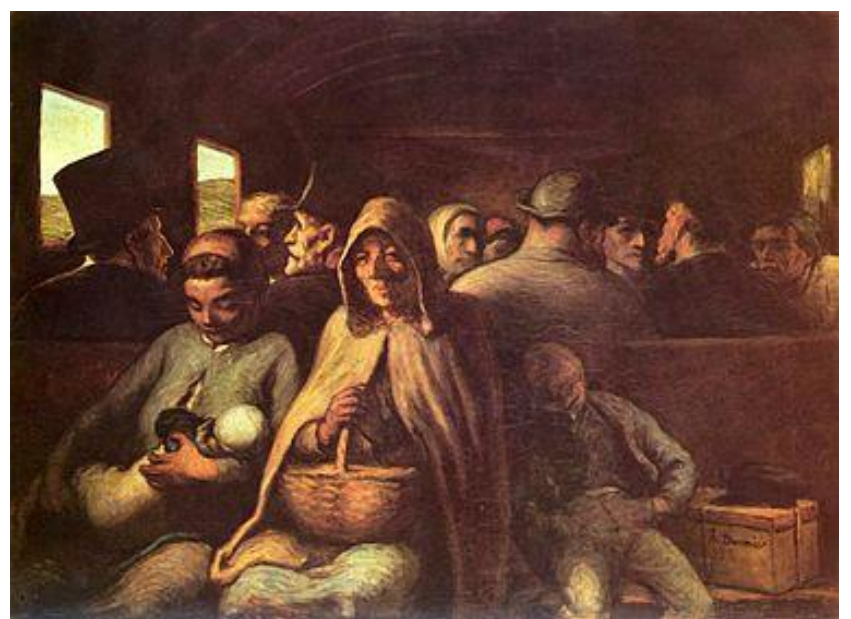

Figura 6 - Honoré Daumier, O Vagão de Terceira Classe, 1862, óleo sobre tela, Galeria Nacional do Canadá, Ottawa, 65,4 x 90,2 cm.

Em 1920, muitos artistas já haviam iniciado a temática do realismo social. As produções da época encontravam-se voltadas para as questões dos operários e da Primeira Guerra Mundial. No Brasil, essas questões já haviam sido levantadas desde a década de 1910 através de movimentos revolucionários pontuais pelo país. Com a criação do Partido Comunista do Brasil em 1922, surgiram vários jornais que mostravam as condições da classe operária, o que também estimulou os ânimos da intelectualidade revolucionária (AMARAL, 1984, p. 33-34).

Carlos Martins relata, no catálogo da exposição Gravura e Modernidade, que no governo Vargas ocorreram muitos movimentos trabalhistas reivindicatórios e que os anseios socialistas e as reações ao nazi-fascismo estimularam os artistas nacionais a uma grande produção da imagética social, como meio de exteriorizar as suas insatisfações e as preocupações com a situação predominante no país (Cf. MARTINS, in Gravura e Modernidade, 2016, p. 15).

No Brasil, Os anos de 1920 a 1940 foram marcantes porque, em meio às mudanças políticas e sociais, a figuração permaneceu em toda produção artística do início do século XX. As características do naturalismo e do realismo ainda podem ser percebidas na produção artística. Na década de 1950, o figurativismo começa a ceder espaço para novas propostas com maior liberdade de expressão e menor preocupação em representar o real. Nesse período, surge confronto entre abstração e figuração (Ibidem, p. 12-16).

Segundo Aracy Amaral (1984), o realismo social no Brasil surge de modos bem diversos entre os artistas voltados para a figuração e inclinação para as questões sociais. Isso era bem comum entre o final dos anos de 1940 até os anos de 1955 aproximadamente. Predominava, na 
época, a preocupação figurativa e outros aspectos políticos, sociais, ideológicos, humanísticos, independentes e ainda alguns preocupados com uma arte nacional. Para a crítica de arte, Katz, assim como os gravadores gaúchos Carlos Scliar e Vasco Prado, comungariam das ideias do realismo socialista fiel ao regime soviético. Portinari e Di Cavalcanti encontravam-se voltados para as questões populares da arte no país e assumiram uma posição de independência, contrária à abstração, embora voltados para uma arte nacional. Desta forma, cada um ao seu modo, buscaram os seus tipos capazes de atender um compromisso nacional livre das ideologias estatais (AMARAL, 1984, p. 161).

No Rio de Janeiro em outubro de 1935, Fabris (2006) conta que Aníbal Machado já reconhecia o estímulo da revista italiana Commune $e^{3}$, que lançou a pergunta: "Para onde vai a pintura?”. Entre as várias respostas dadas à pergunta, torna-se necessário lembrar a de Antônio Berni, que fora o único artista latinoamericano solicitado a responder a pergunta. (FABRIS, 2006, p. 84-85).

Em conferência realizada no Clube de Arte Moderna do Rio de Janeiro durante o encerramento da $1^{\text {a }}$ Exposição Coletiva de Arte Social, Aníbal Machado afirmara que ela foi a "revelação de um novo estado da arte no Brasil, a arte que já começa mostrar uma mobilização revolucionária de sua cultura e consciência política nascente no seio de suas massas". Acrescenta, ainda, que ela contribuiu com a aproximação entre a coletividade e a arte pelo seu caráter popular. A gravura teve na ocasião o seu merecido destaque, porque a maior parte das obras expostas a tinha como linguagem (AMARAL, 1984, p. 50). É necessário lembrar ainda de um contraponto entre a exposição de arte social e a arte das exposições convencionais. Segundo Machado, o público se identificou com a arte social presente no evento porque era uma arte realista, objetiva e popular. Falava do homem em seu espaço e tempo nas suas atividades cotidianas (Ibidem, p. 175).

Ibiapina Martins também acreditava que "os grandes artistas sabem que a arte só pode se enriquecer no contato com as políticas do proletariado e com a consciência sobre as classes dominantes". Acreditava que o artista tinha que permanecer livre e descompromissado para defender as suas ideias, pois só assim seria um ser político livre para criar (Ibidem, p. 139).

De acordo com Amaral (1984), a arte social tinha em Ibiapina Martins um excepcional defensor. No final dos anos 1940 e início dos anos 1950, o crítico demonstrava uma preocupação com a utilidade da arte. A abstração chegara ao país e se expandia pelos museus

\footnotetext{
${ }^{3}$ Commune foi uma revista francesa que veiculou o debate sobre a necessidade da mensagem através da arte e mostrou-se favorável a respeito do desenvolvimento de uma pintura mural no Brasil (FABRIS, 2005, p. 85).
} 
que foram inaugurados e através das Bienais de São Paulo. Os meios de divulgação da arte social eram os jornais que circulavam no período, como o Correio Paulistano, Última Hora, Fundamentos e Notícias de Hoje (Ibidem, p. 138).

Katz manteve-se despreocupada em agradar a burguesia e voltou-se para a situação social do homem trabalhador. Pretendia, com a sua poética, despertar o povo massacrado e promover a visualidade de sua gente e de suas preocupações nacionais. Dedicou muitos anos de seu trabalho ao realismo social. Esperava com isso que ocorressem mudanças culturais e melhoras na condição social do povo brasileiro (Ibidem, p. 175). Desse período produziu as xilogravuras possíveis de serem vistas na seleção que compõe Antologia Gráfica.

Nessa época, era comum o artista executar uma única obra de fundo social, como foi o caso de Picasso ou apenas algumas em um determinado período como descrito acima no caso de Tarsila Amaral (Ibidem, 1984, p. 22). Outros produziam em maiores quantidades as obras com esta temática como ocorrera com Renina Katz que realizou diversos trabalhos em um longo período, de 1948 a 1956. Este fato aconteceu entre artistas nacionais e internacionais. Entre os nacionais que contribuíram também com a sua obra voltada para a mensagem social estão: Carlos Scliar, Lívio Abramo, Portinari, Di Cavalcanti, Oswald Goeldi, Lasar Segall e outros (Ibidem, 1984).

Apesar dos diversos meios para a sua produção no Brasil, a gravura em madeira foi a mais admirada e a mais utilizada, principalmente quando se associava a imagem às impressões textuais. Talvez a xilogravura tenha sido a mais amplamente utilizada por ter a sua origem mais popular, anônima, e também pela técnica ser considerada uma das mais espontâneas. Logo em seguida, houve a implantação de muitas oficinas gráficas que também praticavam a litografia, tanto como recurso tipográfico como na impressão de estampas impressas, por ser considerada uma das técnicas mais práticas, econômicas e atuais com relação à reprodução de imagens (Cf. MARTINS, in Gravura e Modernidade, 2016, p. 9).

A gravura em nosso país foi considerada uma linguagem expressiva e representativa dos temas nacionais, com ampla circulação e consideração. Tornou-se a linguagem visual erudita. Segundo Tadeu Chiarelli, no início do século XX, as gravuras brasileiras já apresentavam elementos do modernismo possíveis de serem visualizados nas produções de pioneiros da gravura moderna, como Lasar Segall, Oswald Goeldi e Lívio Abramo e outros (Cf. CHIARELLI, in Gravura e Modernidade, 2016, p. 7).

As gravuras dos anos de 1920 passaram a ter uma prática intensificada pelo modernismo e as suas repercussões sobre a arte brasileira foram visíveis. Elas contribuíram imensamente 
com a divulgação das artes visuais, assim como impulsionaram o trabalho já existente (Cf. MARTINS, in Gravura e Modernidade, 2016, p. 9-17). Nos anos de 1920, as editoras nacionais buscaram nas gravuras dos artistas um meio de ilustrar as suas publicações - capas, ilustrações e vinhetas. Cresce, assim, uma nova frente para a publicação dessas produções no país. Em Porto Alegre no ano de 1929, a Editora Globo cria dentro da gráfica um departamento para verificar e manter ativa a publicação das gravuras. No Rio de Janeiro em 1931, muitos artistas ilustraram livros, contribuindo dessa forma para a circulação da gravura entre colecionadores (MARTINS, 2014, p.16). Em 1943, as gravuras realizadas por artistas já dialogavam com muitas narrativas nacionais e com narrativas internacionais quando eram traduzidas para a língua portuguesa. Dessa forma, no momento da criação da Antologia Gráfica, a gravura brasileira já era vista como um importante meio expressivo. 


\section{CAPÍTULO 2 - RENINA KATZ E SUA TRAJETÓRIA ARTÍSTICA}

Renina Katz Pedreira nasceu em 1925 em Niterói, Rio de Janeiro. Viveu na mesma cidade, onde seguiu os seus estudos oficiais na Escola Nacional de Belas Artes aos 21 anos. Segundo Katz, na década de 1940, a Escola de Belas Artes se apoiava em todos os princípios acadêmicos de obras copiadas da École des Beaux Arts da França. Renina, juntamente com outros colegas, acreditava que havia a possibilidade de se fazer um outro tipo de arte livre da tradição europeia. No Brasil daquela época, ainda não havia um mercado de arte, nem museus e nem tampouco publicações a respeito.

Katz licenciou-se em desenho pela Faculdade de Filosofia da Universidade do Brasil e, com a chegada do gravador Axl Leskoschek ao Rio de Janeiro, iniciou o curso de xilogravura. Leskoschek causou um intenso movimento entre os artistas locais e começou a dar curso de gravura no Museu de Arte Moderna. Logo, atraiu a atenção dos jovens artistas para os temas nacionais. Neste período, Katz buscava inspiração nas ruas da cidade e nas paisagens cariocas, mas foi na gravura que encontrou ressonância e a sua principal expressão artística. Cursou livremente ateliês de grandes gravadores como Leskoschek e Carlos Oswald, entre outros. Carlos Oswald contribuiu com a formação artística de Katz e com ele a artista aprendeu gravura em metal em 1950 no Liceu de Artes e Ofícios. Desse período, restaram poucas gravuras. Com Leskoschek, a artista descobriu a xilogravura, sua grande paixão, à qual dedicou um grande período da sua produção artística.

Em entrevista a Laurita Salles no ano de 1993, a artista disse que as gravuras japonesas a teriam fascinado. Então, iniciou a sua pesquisa sobre gravura. Surgiram, assim, Frans Masereel, um expressionista belga, Käthe Kollwitz, Munch e Axl Leskoschek dentre outros.

Renina Katz reconhece a importância de Leskoschek em sua formação. Ele, experiente artista austríaco, chegou ao Brasil trazendo muitos conhecimentos técnicos sobre gravura e aqui alcançou maturidade expressiva. Estimulado pelas questões do exílio e pela Segunda Guerra Mundial, atingiu uma distinção incalculável sobre as questões humanitárias. Foi pintor, gravador e professor e se instalou na cidade do Rio de Janeiro durante os anos de 1940 e 1948. O gravador influenciou o ambiente da arte nacional do período, ao participar da formação de novos artistas, dentre eles estão Renina Katz, Fayga Ostrower, Ivan Serpa e Edith Behring. Todos gravadores que contribuíram muito com a história da gravura nacional. $\mathrm{O}$ artista austríaco lecionou na Fundação Getúlio Vargas, onde a xilogravura foi a sua linguagem mais explorada. Axl Leskoschek realizou muitas xilogravuras que ilustraram obras literárias brasileiras e estrangeiras. Estas obras foram publicadas quando trabalhou para a Editora José 
Olympio no Rio de Janeiro. Dentre elas, podemos citar todas as versões brasileiras de obras de Dostoiévski, como Os irmãos Karamazov traduzido por Raquel de Queiroz em 1940. Produziu mais de duzentas gravuras em vários tamanhos ilustrando essa narrativa.

Tanto Renina Katz como Axl Leskoschek debruçaram sobre a arte de denúncia, mostrando-se atentos à ordem social e política muito comum entre os jovens militantes da época. Após o contato com Leskoschek, Katz descobriu que só por meio da xilogravura - com os seus cortes, as suas incisões e através da força dessa linguagem - ela conseguiria o que necessitava para o seu projeto de denúncia social. Nesse período, encontrava-se engajada politicamente e produziu as séries que compõem Antologia Gráfica. De Leskoschek, Katz herdou a humanidade das suas figuras, a sua adequação formal, sociocultural e emocional à verdade humana e literária dos personagens (NEISTEIN, 2016. p. 3-9).

Katz foi realmente seduzida pela xilografia, voltando-se aos estudos sobre alguns gravadores, principalmente sobre os mexicanos. Começou a olhar o que Posada e Leopoldo Mendez faziam. Leopoldo Mendez era um excelente gravador e fundou o Taller de Artes Gráficas do México. Renina, então, voltada para o mesmo propósito, buscava gravuras populares nos moldes da época do Posada, tempos de revolução. Ela afirma ter continuado a sua produção voltada para o mesmo propósito de 1948 a 1956, período em que as gravuras da Antologia Gráfica foram elaboradas (BITTENCOURT, p. 21-22).

Outra artista que teria inspirado Renina Katz foi Käthe Kollwitz. As suas gravuras refletiam direta e indiretamente no seu tempo através dos temas sociais que foram uma constante em sua produção inicial. Agiam diretamente na confecção de cartazes contra a guerra, a fome, a miséria e os aspectos sociais e políticos pela qual a Alemanha passava no princípio do século XX. A obra de Kollwitz ultrapassou os continentes, seja pelo caráter universal, pela beleza das formas e/ou pela definição da sua estrutura de composição. As suas gravuras exerceram influência no Brasil e na China. Nos anos de 1930 a 1950, teria influenciado artistas gráficos em nosso país (SIMONE, 2004, p. 18). As gravuras da artista alemã circulavam principalmente no sul do Brasil, provavelmente trazidas pelos imigrantes europeus (DUPRAT, 2013, p. 750-752):

A presença de Käthe Kollwitz, no Rio Grande do Sul, é mais documentada e estudada a partir da atuação dos Clubes de Gravura e da revista Horizonte. Porém, pode-se inferir que o trabalho da artista era conhecido através das coleções e dos impressos de imigrantes, alemães, principalmente, já nos primeiros anos do século XX. Sabe-se que Carlos Scliar, quando criança, frequentava a Livraria Internacional, propriedade do imigrante anarquista alemão Friedrich Kniestedt, onde se encontrava diversas publicações europeias com reproduções de Kollwitz (Ibidem, 752). 
Renina Katz pertenceu ao grupo de gravadores que tiveram as suas formações por volta dos anos 1940. Ela esteve envolvida nos anos de 1950 em muitos momentos importantes para a construção da história da gravura brasileira, dentre eles, as atividades de docência em desenho e gravura no Museu de Arte de São Paulo de 1952 a 1955, instituição recém-inaugurada, como também na Universidade de São Paulo, onde lecionou na Faculdade de Arquitetura e Urbanismo (Cf. AMARANTE, 1997, p. 20-21).

Katz, como educadora, desempenhou sua função durante muitos anos e demonstrou um compromisso na formação de outros artistas tanto em São Paulo como no Rio de Janeiro. Nesse período, lecionou várias disciplinas e conviveu com grandes profissionais da arte brasileira como Fayga Ostrower, Aloísio Carvão, Décio Pignatari, Frederico de Moraes e outros que, juntamente com Katz, contribuíram também com a expressão artística nacional (Ibidem, p. 2122).

Na vertente do realismo social, destaco uma mostra da artista e dos seus alunos no Rio de Janeiro em 1951 no Diretório da Escola Nacional de Belas Artes, organizada pelos alunos da artista. Essa exposição apresentou trabalhos de 1949-1950. Entre as melhores obras, segundo Mário Barata, estavam moça e criança na calçada. Provavelmente estava se referindo à gravura Maternidade, realizada com grafismo livre e sensível, como nota o autor (Cf. BARATA, Katz, 1950).

A artista seguiu, expondo em outros momentos, em 1952 e em 1953, uma delas no Museu de Arte de São Paulo com a exposição intitulada Renina Katz: gravuras e desenhos e, em seguida, no Museu de Arte Moderna de São Paulo com a mostra Renina Katz: gravuras.

Nos anos de 1956 a 1988, durante a sua atividade de docência na Faculdade de Arquitetura e Urbanismo da Universidade de São Paulo, teve a iniciativa inovadora de apresentar treze litografias com o tema A Cidade como trabalho de conclusão para a sua tese de doutorado. Durante este período atuou junto a outros arquitetos renomados do Brasil, na construção de painéis para escolas, centros de cultura e para a estação do metrô da Praça da Sé em São Paulo, onde criou um grande painel interativo de 30 metros lineares com 55 quadros modulares na vertente da optical art, que é considerado um dos trabalhos mais expressivos de Katz (Cf. AMARANTE, in KATZ, 1997, p. 12 e 34-37).

Renina manteve-se, por um longo período, voltada para o naturalismo figurativo. Somente em 1960 iniciou com a abstração para logo em seguida entrar de vez na abstração figurativa com uma arte de denúncia política em Cárceres ou por meio das gravuras realizadas a partir da leitura do romance $O$ Vermelho e o Negro de Stendhal (Ibidem, p. 28- 32). 
Katz apresenta uma trajetória artística marcada por novos posicionamentos ideológicos e aberta às novas possibilidades no campo da arte. Essa característica contribuiu para que a artista transitasse nas diversas linguagens, desenho, xilografia, linoleografia, serigrafia, litografia e aquarela. Pude verificar, nos dois dossiês pesquisados sobre Renina Katz (um no MASP e outro na Estação Pinacoteca de São Paulo), que está presente no discurso da artista uma consciência da importância da autocrítica e uma busca constante de novos direcionamentos.

A artista considera um equívoco a sua visão sobre os temas sociais, por considerá-la uma visão de classe realizada através de certa dramaticidade mais literária do que formal. De repente percebeu que o seu trabalho estava tomado por conteúdo construído pelo próprio trabalho gráfico altamente disciplinado. A alta qualidade da gravura acabou afetando a própria mensagem, apesar de estar lidando com temas como a pobreza, a miséria e a desigualdade de distribuição de renda (Ibidem, p. 31).

Em entrevista a Vera Beccari publicada no jornal O Estado de São Paulo de 4 de outubro de 1981 e intitulada Renina Katz, a artista afirma que o seu potencial existencial ficou contido pela ênfase dada em seu processo social até 1956. Assim, segundo Katz, seu potencial existencial só foi exteriorizado na década de 1960 por meio da serigrafia e, logo em seguida, plenamente exposto através da litografia e da aquarela, quando pôde realizar uma produção mais livre.

Dentre as exposições internacionais que a artista participou, podemos citar algumas que ocorreram em Washington, no México, Lisboa, Roma, Polônia, Suíça, Chile, Estados Unidos, Portugal, Espanha, Itália, Alemanha. Em Londres, ocorreu uma exposição onde havia apenas artistas mulheres e brasileiras. Katz participou também, por duas vezes, da Bienal de Veneza nos anos de 1956 e 1986. Na segunda mostra, ela apresentou aquarelas de grande dimensão (Catálogo sobre a Doação da Artista ao Museu Nacional de Belas Artes, Renina Katz, Gravuras, 2007-2008).

Em 1956, Katz publicou o seu primeiro álbum de gravuras chamado Favela e percebeu que a sua xilogravura do realismo social atingiu o extremo da técnica e perdeu a sua força, a sua função como arte de denúncia (BITTENCOURT, 2008, p. 7-25). Esse período coincidiu com a sua crise ideológica que foi necessária para definir a recondução do seu percurso (Cf. AMARANTE, 1997, p. 8-11).

Durante a produção das gravuras que viriam a ser selecionadas para Antologia Gráfica, a artista percorria sozinha as ruas da cidade do Rio de Janeiro e posteriormente as de São Paulo, 
em busca de imagens sensíveis que expressassem a situação social em que se encontrava o Brasil. Estes momentos de flâneur, associados a sua capacidade de observação, de olhar em volta e sentir a condição humana e o seu meio estão presentes em toda a sua produção. A observação era seguida pela elaboração dos desenhos e, posteriormente, em seu ateliê eram finalizados ou reelaborados com a disciplina e a persistência adquiridas pelo longo e trabalhoso processo criativo da artista (Ibidem, p. 8/23). Nas gravuras que compõem o álbum em estudo, podemos visualizar disciplina, persistência e pesquisa na sua elaboração, que também estão presentes em outras fases posteriores da sua obra, como em Os Cárceres, O Vermelho e o Negro e nos álbuns Territórios Imaginários e Transfiguração onde podemos visualizar as litogravuras dessas séries e perceber a ligação de Katz com a pesquisa voltada para as questões das paisagens visuais (Cf. AMARANTE, 1997, p. 56-169).

Renina Katz é uma artista que, no pós-guerra, comungando dos ideais comunistas efervescentes, participou dos movimentos estudantis. Foi representante no Diretório Central dos Estudantes (DCE), na União Metropolitana dos Estudantes e na União Nacional dos Estudantes (UNE). Escolheu a xilogravura como linguagem e fez uma arte engajada e figurativa. Construiu uma enorme quantidade de figuras que retratam cenas do contexto nacional, fáceis de serem entendidas pelo público, um dos objetivos comuns entre os artistas nos anos de 1940 aos de 1950. Carlos Scliar e Renina Katz foram grandes produtores destas imagens de denúncia no país e contribuíram para a formação da gravura brasileira como linguagem artística (SIMONE, 2004, p. 199-201).

\subsection{Inspirações de Katz}

No Brasil, Käthe Kollwitz (1867-1945) tornou-se exemplo de artista social nos anos 1930, perceptível nos discursos de artistas e de intelectuais vinculados às correntes socialistas do Clube dos Artistas Modernos e da Sociedade Pró-Arte Moderna. Nos anos de 1940 e 1950, Kollwitz é uma referência importante do realismo socialista. Kollwitz teve os seus trabalhos divulgados e publicados em revistas como Fundamentos, de São Paulo e Horizonte, de Porto Alegre (DUPRAT, 2013, p. 743).

Segundo Katz, o Expressionismo e a arte social foram fonte de inspiração sobre a execução de seus trabalhos. Como podemos ver abaixo, Katz afirma que Kollwitz a inspirou diretamente: 
Eu sou realmente da geração pós-guerra. E isso é importante porque todo o meu trabalho nesse período estava marcado pela situação que vivíamos [...]. Aquela era uma época de rebelião, de protesto, de afirmação ideológica [...]. Tivemos toda uma aproximação com o Expressionismo, e também com alguns mexicanos, como o Posada, o Leopoldo Mendez [...]. Essas influências, que eram fortes do ponto de vista da temática social, atingiram muito a minha geração [...]. Esse assunto, quer dizer, a miséria, a pobreza, a má distribuição da riqueza, enfim, todos os temas que o Expressionismo alemão muito antes já tinha tratado, ecoou aqui entre nós com muito vigor [...]. Durante uns dez anos foi mais ou menos o que fiz [...]. O meu modelo eram os expressionistas mais dramáticos, militantes [...]. Não era exatamente o Munch, mas a Käthe Kollwitz [...]. (SIMONE, 2004, p. 200).

É possível verificar em sua obra que Katz manteve-se militante política ativa no período de transição do final da Segunda Guerra Mundial, gravando as suas séries figurativas e as divulgando através do Movimento de Joaquim, que contou com a liderança de Poty Lazzarotto. Ele levava a produção de jovens artistas do Rio de Janeiro para a revista paranaense onde atuavam também Scliar, Athos Bulcão e outros artistas. Esse fato contribuiu para a difusão da obra de Katz entre o público (BITTENCOURT, 2008, p. 17-19). Katz esteve em contato com artistas nacionais, como Portinari, Guignard, Carlos Scliar, Poty e outros, que nesse contato estabeleceram algumas orientações que contribuíram com a sua produção artística (Ibidem, p. 17-19).

Katz encontrava-se constantemente presente entre os jovens artistas mais ativos dos cursos oficiais de pintura e arquitetura do Rio. Nesse período, havia muitas revistas circulando, como Leitura e Renovação e era frequente, nas agendas culturais, debates em volta das exposições realizadas, inclusive trazidas para o país. Estes fatores causavam reflexões e inquietudes políticas e estéticas. Renina Katz, mobilizada por seu espírito inovador e inquietude criativa, participou e esteve atenta as tendências estéticas e deixou que as mesmas interferissem no seu modo de ver o mundo e na sua singular produção. Katz, ao ser questionada sobre as razões de ser da sua arte, afirma:

\begin{abstract}
A arte deve aproximar-se da vida, disse-nos, da realidade. Num país como o nosso de pouca divulgação artística, a gravura é um meio de expressão que pode atuar em todas as classes sociais. Pelo seu baixo preço pode expandir-se muito. Se a gravura é boa pode agir sobre o público mostrando as coisas más que existem na vida atual e as boas que podem e devem vir, para mim é isso o realismo é o que pretendo fazer. Na época em que vivemos não se pode isolar a arte da vida, pois ela é um fenômeno como outro qualquer. Hoje não cabe, senão o realismo (Ibidem, 2008).
\end{abstract}

Nos anos 1930, ocorreram duas exposições sobre a produção de Käthe Kolwitz: uma em 1930 no Rio de Janeiro e outra em 1933 no Rio e em São Paulo. Em 1930, a mostra coletiva Exposição de Livros e Artes Gráficas trouxe algumas obras de Kollwitz oficialmente ao Brasil. Nesta ocasião, contaram ainda com desenhos e gravuras de Otto Dix, Karl Schmidt-Rottluff, 
Oskar Kokoschka, Georg Grosz e Max Liebermann. Essa ocasião, Katz estabeleceu os primeiros contatos com os trabalhos da artista alemã (SIMONE, 2004, p. 183).

Em 1933, a exposição foi dedicada exclusivamente a Kollwitz na Galeria Heuberger no Rio de Janeiro. Na época, Theodor Heuberger dirigia a Associação Pró-Arte. Neste mesmo ano, Flávio de Carvalho dirigia o Clube dos Artistas Modernos (CAM) de São Paulo, e teria assinado um acordo com Theodor Heuberger, que previa um intercâmbio de exposições. Dentre elas, estava prevista esta mostra de Käthe Kollwitz na capital paulista de 1 a 20 de junho de 1933 . Como podemos verificar, havia um forte engajamento político e social no CAM de São Paulo nos anos de 1932 e 1933. Kollwitz se torna uma referência importante para os seguidores do realismo socialista nos anos de 1940 a 1950 no Brasil (Ibidem, p. 185-186). Segundo Pedrosa (AMARAL, 1984, p. 278): “(...) o ambiente de alta tensão social e crise institucional não permitia mais as explosões puramente estéticas e culturais da Semana".

A gravura de Kollwitz, onde os trabalhadores podem ser vistos em A Marcha dos Tecelões (1897), mobilizou os sentimentos sociais em grande parte do mundo, inclusive no Brasil. Essa gravura mostra um grupo de pessoas, entre homens, mulheres e crianças com expressões sofridas, apresentando a exaustão física causada pela miséria, pelo sofrimento psicológico resultante de um sistema econômico cruel (DUPRAT, 2013, p. 744). A luz na obra da artista vem do horizonte, um grande espaço em branco na gravura que invade toda a cena. A composição dos corpos é definida por fortes linhas e texturas.

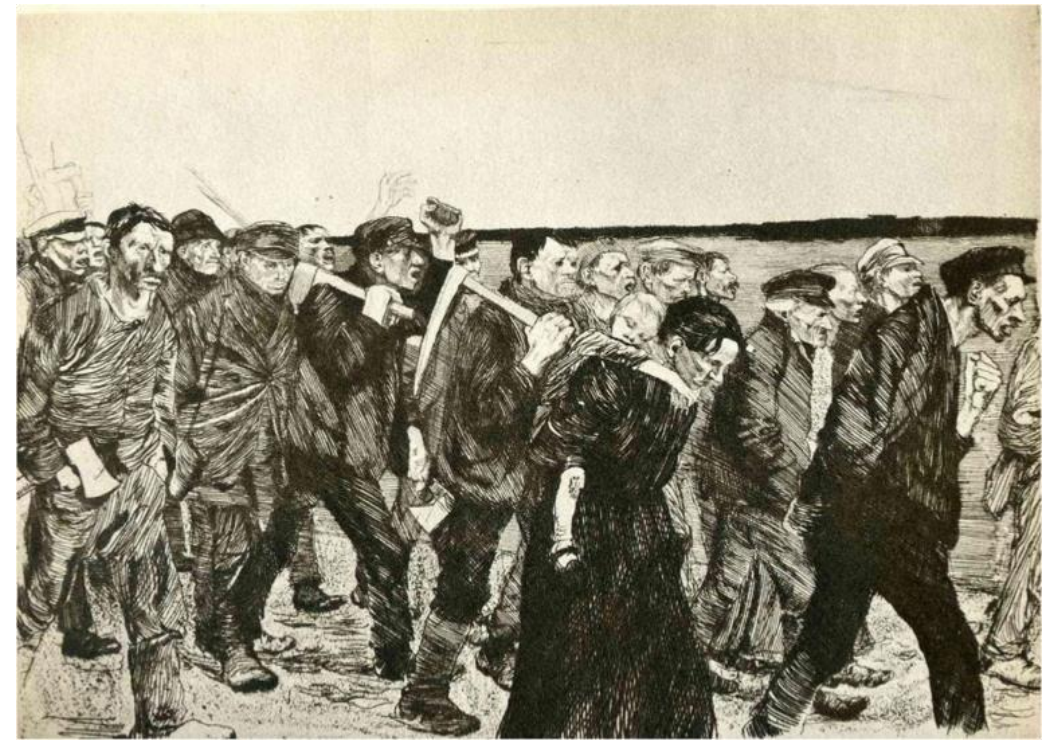

Figura 7 - Käthe Kollwitz, A Marcha dos Tecelões, 1897, gravura em água-forte, 21,6x 29,5 cm.

Como Kollwitz, Katz também retrata multidões em caminhada, como podemos ver na gravura Retirantes, ao observar a chegada dos migrantes para o trabalho no campo. As figuras 
também atestam expressões sofridas e um caminhar por uma vida mais digna. Em Kollwitz, a imagem se passa linearmente na frente do observador, enquanto em Katz a imagem avança na diagonal e se movem para a esquerda da superfície do papel. A luz de Katz mais uma vez surge do contraste criado entre as suas linhas, intercalando entre as saliências da madeira e os seus sulcos, contribuindo para limitar os corpos que compõem o bloco. A porteira entreaberta simboliza um encontro entre os dois mundos, os trabalhadores que chegam em busca de trabalho e os proprietários que exploram a força de trabalho. Em Kollwitz, na obra Ataque (1897) "o portão como elemento figurativo, domina a cena, no centro da composição. Em torno dele, a ação se desenvolve". O portão de Kollwitz "é o próprio símbolo da diferença de classes, isto é, um importante elemento de um drama social” (SIMONE, 2004, p. 77).

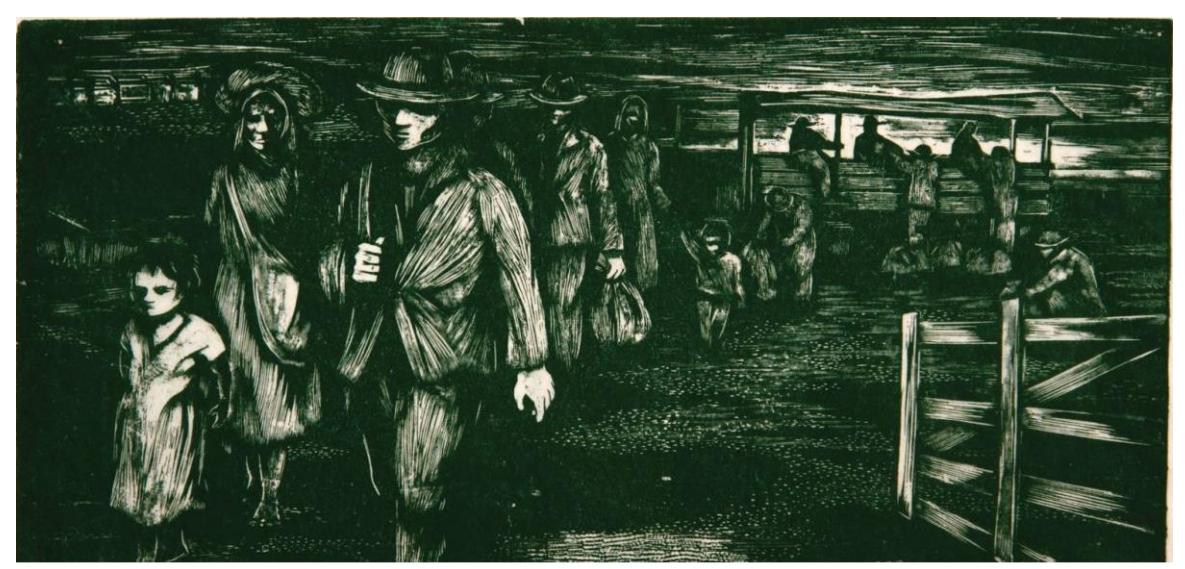

Figura 8 - Renina Katz, Retirantes, 1948-1956, gravura, Fundação Armando Alvares Penteado, São Paulo, 15,8 $\mathrm{x} 28,7 \mathrm{~cm}$.

Na obra de Kollwitz, assim como na de Katz, podemos verificar também cenas de mães, pais e crianças famintas, em situações de miséria devido às consequências desastrosas da guerra e da precariedade que dão origem à fome. As gravuras Fome (1923) de Kollwitz e Retirantes (1956) de Katz ilustram esta situação e apresentam a figura construída e sintetizada a uma única massa escura em ambiência rude e precária. Podemos pensar que Katz compôs Retirantes inspirada por Kollwitz e o expressionismo alemão, como podemos constatar através das semelhanças entre as figuras abaixo. 


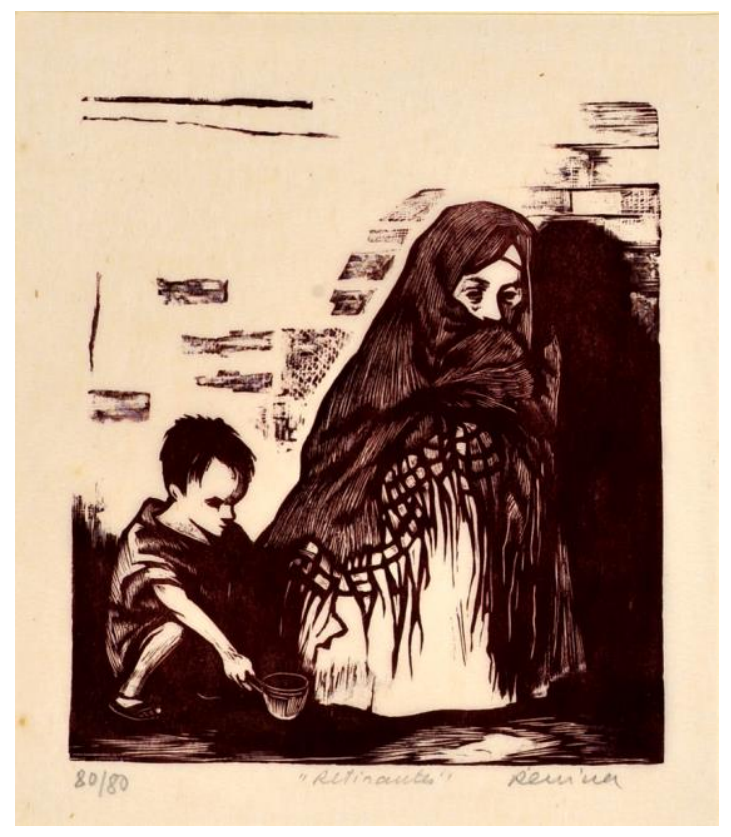

Figura 9 - Renina Katz, Retirantes, 1948-1956, gravura, Fundação Armando Alvares Penteado, São Paulo, 18,2 $\mathrm{x} 15,9 \mathrm{~cm}$.

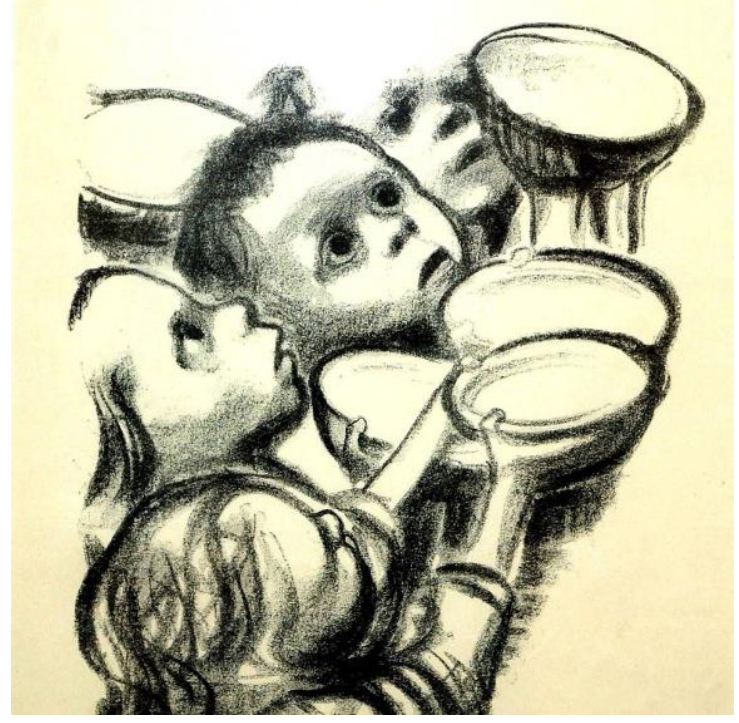

Figura 10 - Käthe Kollwitz, Fome, 1924, carvão vegetal, 35 x 50 cm.

Em 1951, ocorre a I Bienal do Museu de Arte Moderna de São Paulo, que trouxe obras de vários artistas nacionais e internacionais e, dessa forma, estimulou bastante o debate entre os nossos artistas e ampliou os seus olhares para fora do país - o que segundo Katz contribuiu com a sua produção artística (BITTENCOURT, 2008, p. 26-27).

Amaral (1984) reconhece que a criação dos museus em São Paulo e a Bienal realmente mudaram o cenário artístico nacional e considera que as ilustrações desse período se colocaram entre a abstração e a figuração. No entanto, as representações figurativas se apresentaram indiferentes à abstração e aos novos movimentos artísticos que se instalaram no país, tanto o paulista, Concretismo, e o carioca, Neoconcretismo (AMARAL, 1984, P.237-238). 
Quando abandona a temática social, Katz apresenta uma fase geométrica com experimentos cromáticos e começa a fazer serigrafias com algumas abstrações. A artista reconhece que nunca se interessou pelo concretismo porque esse movimento não se utilizava da geometria como solução formal. Ele tinha outra intenção que, segundo Katz, ela não concordava com seus pressupostos (BITTENCOURT, 2008, p. 33-34).

O tema cidade ocupou um lugar tão importante assim como o campo no impressionismo. Os artistas passaram do verde do campo, da luz do sol á aridez desumana e à fumaça das fábricas nas cidades. A cidade esteve por muito tempo sendo representada como o antinatural e as representações do campo muitas vezes como um alívio a atmosfera asfixiante das cidades ((SCHAPIRO, 2002, p. 122).

Podemos imaginar, através das duas gravuras com o tema de cidade que seguem abaixo, uma passagem da artista da figuração para uma sutil abstração:

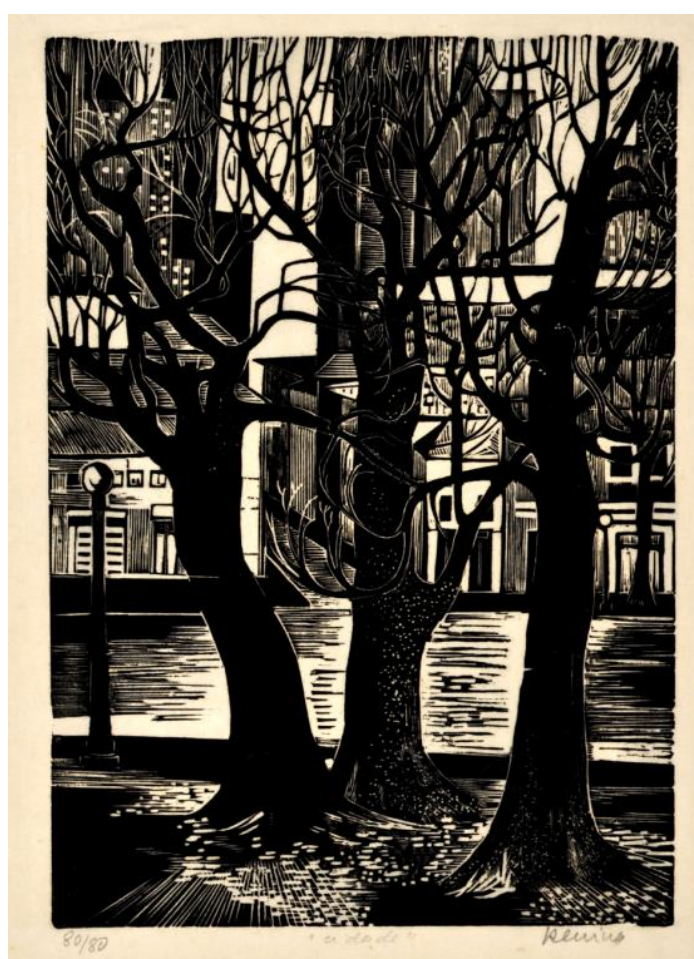

Figura 11 - Renina Katz, Cidade, 1948-1956, gravura, Fundação Armando Alvares Penteado, São Paulo, $28,2 \times 20.2 \mathrm{~cm}$.

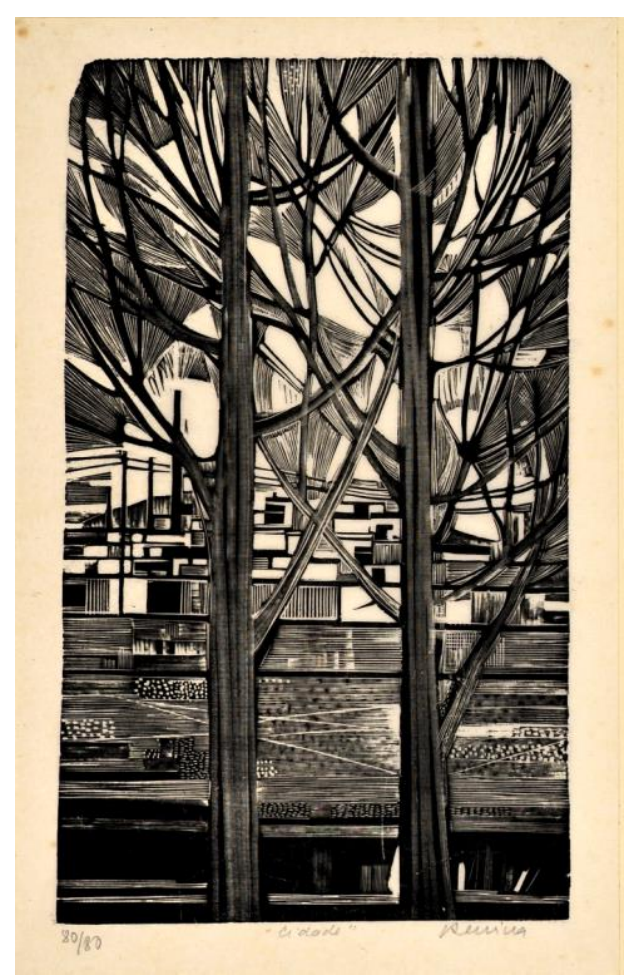

Figura 12 - Renina Katz, Cidade, 1948-1956, gravura, Fundação Armando Alvares Penteado, São Paulo, 29,6 x 18,5 cm.

Podemos verificar este aspecto também presente na abstração da A Árvore Vermelha (1908 e 1910) que Piet Mondrian, representa um primeiro esforço de abstração, no sentido em que tenta abstrair-se da realidade que rodeia a árvore, para a retratar com cores não naturais. Ao fundo da pintura esboça-se o contorno de uma cidade por trás da árvore, o Mondrian mostra como se processou a desconstrução figurativista de sua obra. $\mathrm{O}$ artista parte 
da figuração através de várias etapas até atingir uma franca abstração como podemos verificar nas imargens abaixo:

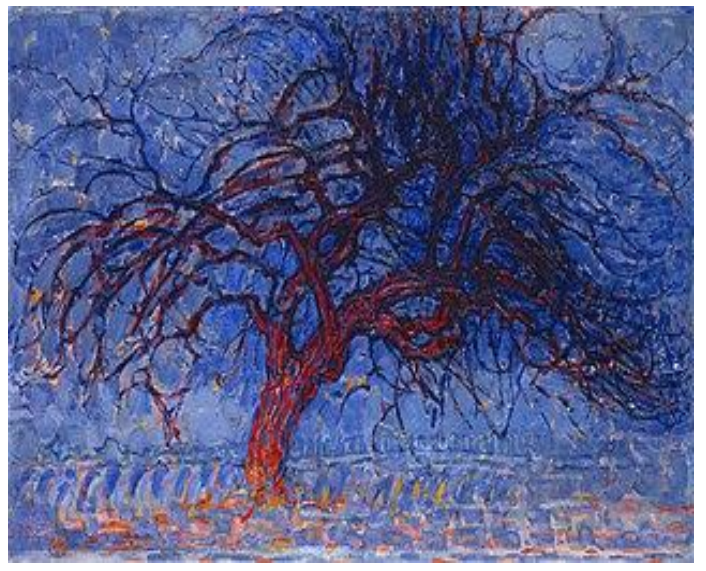

Figura 13 - Piet Mondrian, A árvore vermelha,1909/1910, óleo sobre tela, 70 x 99 cm, Gemeentemuseum, Haia, Holanda.

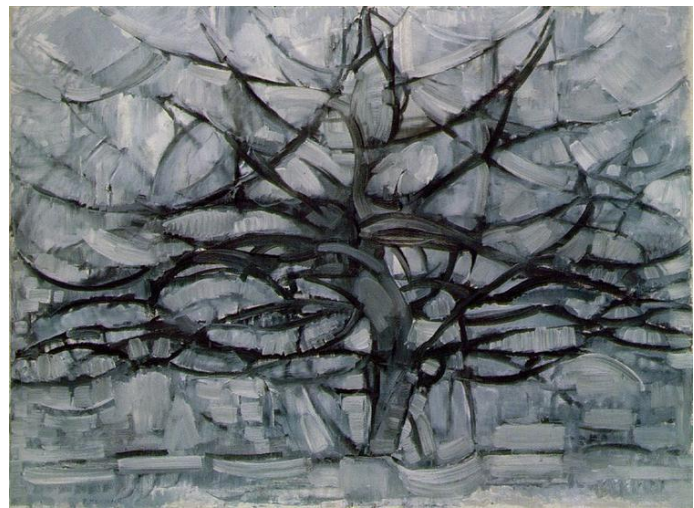

Figura 14 - Piet Mondrian, A árvore cinzenta, 1911, óleo sobre tela, 78,50 × 107,5 cm, Museu Municipal de Haia.

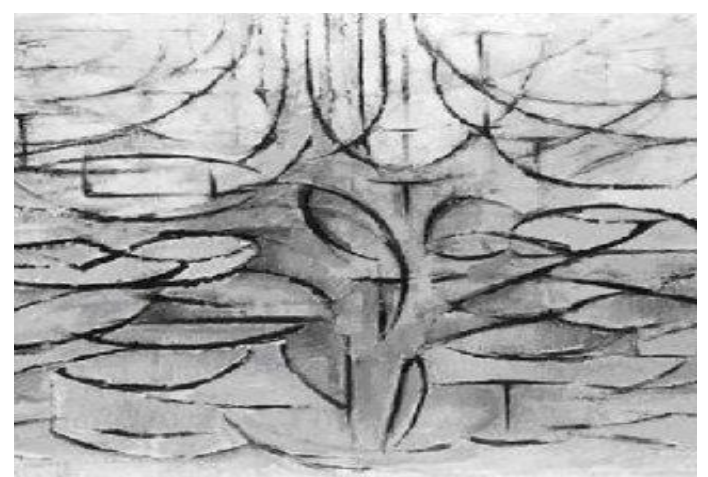

Figura 15 - Piet Mondrian Macieira em flor, 1912. Óleo sobre tela, $78 \times 106$ cm, Gemeentemuseum, Haia, Holanda 
Somente na década de 60, a artista, através da litogravura, mergulha rapidamente na abstração como expressão poética presente até hoje em seus trabalhos, mas permanece voltada ainda para as questões políticas e sociais. Posteriormente, ela entra com toda força nos temas sobre lugares e revela cenários de cidades, campos e atmosferas também através da litogravura. O texto a seguir evidencia o interesse de Katz pela geometria:

Também sempre gostei muito da geometria que, de algum modo, compareceu e comparece no meu trabalho. Tive uma fase em que fiz várias pinturas sobre o Teorema de Pitágoras, que é um tema fascinante para mim. A geometria descritiva me ajudou a pensar o espaço. As serigrafias dos anos 1970 são um exemplo de como ela está presente no meu trabalho (BITTENCOURT 2008, p. 34-35).

Com a série Cárceres realizada em 1979, composta por litografia a cores, Katz continua o seu processo a caminho da abstração. Na obra, predominam a geometrização e a abstração, que são descritas através de linhas longas, retas ou diagonais que riscam o plano entre si ou através de linhas curvas. Nesta obra, ainda é possível visualizarmos a presença do figurativo, representado por pássaros, imagem de mulher, grades, céus, natureza e o solo, como podemos verificar abaixo:

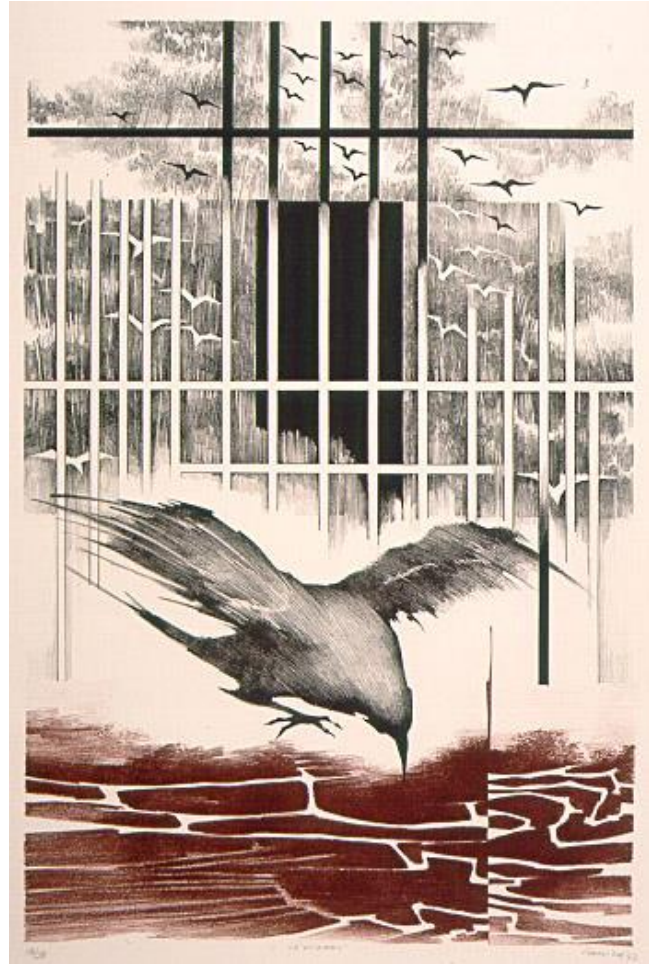

Figura 16 - Renina Katz, Cárceres, 1979, litogravura a cores, Museu Nacional de Belas Artes, Rio de Janeiro, 52 × $34 \mathrm{~cm}$.

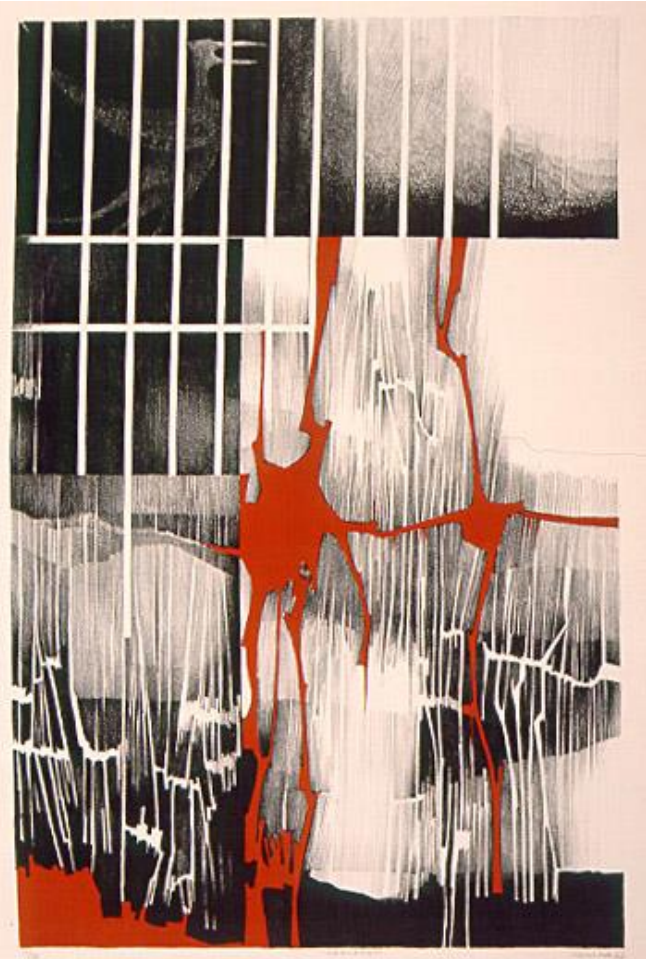

Figura 17 - Renina Katz, Cárceres, 1979, litografia a cores, Museu Nacional de Belas Artes, Rio de Janeiro, $50,8 \times 33,8 \mathrm{~cm}$. 


\subsection{Katz e a atividade de Ilustração}

A atividade da ilustração esteve junta a da narrativa desde a Antiguidade, quando imagem e texto estavam presentes nos livros da época (AVELAR, 2007, p.83). A ilustração esteve presente nos livros sagrados através da iluminura, quando ilustrou o Antigo, o Novo Testamento e os Evangeliários. Nesse período, havia apenas as técnicas da iluminura e a xilografia. O Livro dos Mortos de Ulrich Bonner, de 1461, é considerado o primeiro livro ilustrado.

No século XX, havia também a possibilidade de desenvolver trabalhos ilustrativos e vários artistas brasileiros buscaram a ilustração como forma de divulgação de suas produções. Desse modo, muitas obras literárias de escritores nacionais e internacionais foram ilustradas por Leskoschek, Oswald Goeldi, Lívio Abramo, Carlos Scliar, Renina Katz e muitos outros (Cf. MARTINS, 2014, p. 15).

Na tese de doutorado de Ana Cândida de Avelar (2007), podemos verificar em sua análise sobre as ilustrações do Suplemento Literário do jornal $O$ Estado de São Paulo, nos anos de 1956 e 1974, que Katz participou dele com suas ilustrações de altíssima importância para a cultura brasileira. Apesar da sua pouca participação, ela colaborou, através de desenhos e gravuras, para artigos, poemas e contos. Houve ocasiões em que apenas publicaram seus trabalhos de modo livre, sem vínculo literário ao suplemento.

No Suplemento, era dado às ilustrações e fotografias artísticas o mesmo valor de importância concedido aos contos e poemas. As suas capas foram frequentemente ilustradas com reproduções de jovens artistas nacionais e internacionais, como as ilustrações da própria Renina Katz, Fernando Lemos, Aldemir Martins, Lívio Abramo, Maria Bonomi e de artistas como Di Cavalcanti e Portinari. Nesse sentido, surge a atuação dos nossos artistas que contribuíram para isso e tiveram os seus trabalhos divulgados (FERNANDES, 2007, p. 20). Segundo Katz, a multiplicidade da gravura a seduz porque não há a obra única, pois é generosa e evita a escassez (BITTENCOURT, 2008, p. 22-23). Neste contexto, a divulgação de desenhos, gravuras e ilustrações pelo Suplemento contribuiu para tornar conhecida a arte brasileira em período de intensa discussão sobre o Concretismo, Neoconcretismo e as Bienais (FERNANDES, 2007, p. 24).

Katz reconhece que o Suplemento atendeu ao seu propósito como meio de divulgação do seu trabalho e de seu nome em momento de debate sobre a necessidade de uma arte voltada para o povo. Katz acreditava que, através das gravuras, ela conseguiria enviar a sua mensagem social. A atuação do Clube de Gravura de Porto Alegre na década de 1950, através de Carlos 
Scliar e Vasco Prado, divulgou obras sobre o realismo social, em xilogravuras e linóleos produzidos e publicados na revista Horizonte. Outro fator relevante é o que Lourival Gomes Machado coloca (Ibidem, p. 25):

Hoje, invertidas as funções e posta a imagem a serviço da arte, a reprodução gráfica realizada em todas as técnicas, dimensões e preços permite uma aproximação da obra de arte que, há poucos anos, permanecia reservada aos raros.

Segundo Fernandes (2007, p. 25), o pensamento de Lourival Gomes Machado nos permite entender a frase de Renina Katz sobre o Suplemento e a sua contribuição como "um veículo de divulgação de seu nome e de sua arte no mesmo momento em que se intensificava o debate sobre os meios de popularizar as artes visuais".

Entretanto, depoimento de Cacilda da Costa manifesta discordância de que a divulgação pelo Suplemento foi tão efetiva como Katz pensava:

\footnotetext{
Havia toda uma ideologia de esquerda, de popularização da obra de arte, uma ideia de que a obra de arte não deveria ser uma coisa burguesa que enfeitaria a casa das pessoas que podiam pagar. Principalmente os gravadores, pela própria natureza da gravura, sentiam-se privilegiados nesse sentido por podem fazer obras acessíveis a todos. (FERNANDES, 2007, p.25-26).
}

Katz, até 1952, havia realizado poucos trabalhos de ilustração de livros. Ela atribui esta pequena produção de ilustração ao fato de sua pouca aptidão para o gênero, mas não por restrição. Em 1953, ao ler O Romanceiro da Inconfidência de Cecília Meireles, Katz contou que, quando terminou a leitura, começou a desenhar sem parar. Ficou encantada com essa narrativa da literatura brasileira, pelos versos fluindo com tanta força e emoção e, ao mesmo tempo, com tanto realismo (Cf. AMARANTE, in KATZ, 1997, p. 32-34).

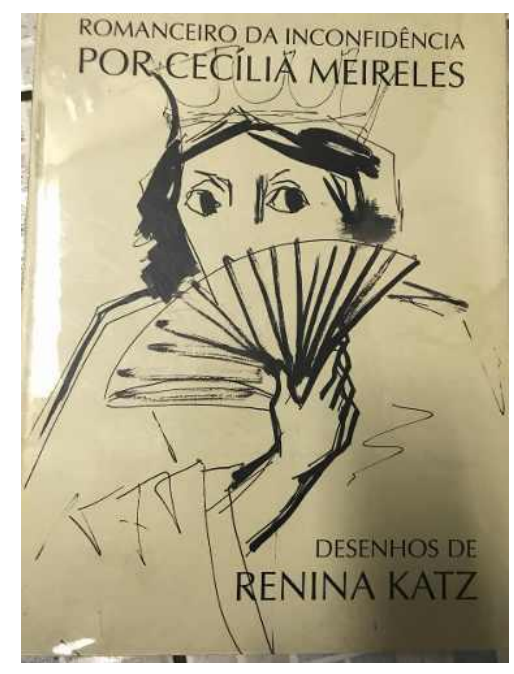

Figura 18 - Renina Katz, O Romanceiro da Inconfidência, 1953, Ilustração para capa de livro, Centro de Documentação da Estação Pinacoteca, São Paulo. 
Para essa obra, a artista produziu mais de duzentos desenhos preparatórios para as gravuras que fariam parte de um conjunto formado por texto e imagem e que seriam capazes de dialogar entre si e manter o clima lírico que predomina no conjunto formado entre a narrativa de Cecília Meireles e os desenhos da artista. Dentre esses desenhos, só foram publicados algumas das ilustrações junto à poesia em 2004, depois de muito empenho por iniciativa de vários interessados na gravura e na história do país. Dentre eles, podemos destacar Elsio Motta, empresário das artes gráficas paulista e que acolheu muitos artistas brasileiros em sua gráfica, e o colecionador e bibliófilo José Mindlin, descobridor da existência dos desenhos elaborados por Katz. Essas ilustrações significam um momento marcante no caminho da produção da artista e, segundo ela, marca a sua transição entre a figuração e o que viria a produzir posteriormente (BITTENCOURT, 2008, p. 35-38), conforme podemos ver abaixo:

(...) o tratamento do espaço e da matéria gráfica continha os elementos básicos que iriam se desdobrar nos trabalhos de uma nova fase. Do realismo figurativo foi resgatado um repertório da sintaxe visual, fundamental para o desenvolvimento de novo projeto, onde o compromisso com a temática explícita já não era relevante. Acredito que entre outras, esta seria a razão pela qual os desenhos do Romanceiro conseguiram sobreviver despertando sempre interesse renovado, ao menos para mim (KATZ, 1989).

Angela Cruz, em matéria do Jornal da Bahia em 1982, sob o título de Romanceiros da Inconfidência, nos lembra que apenas no século XX uma série de artistas gravadores aderiram à ilustração de livros, tais como Odilon Redon, Chagall, Roualt, Picasso e outros que utilizaram uma variedade de técnicas de gravura e litogravura. Cruz considera a atividade ilustrativa complexa porque requer do artista muita sensibilidade e afinidade com o autor. A ilustração de livros, jornais e revistas perdura até os nossos dias. Há, nessa atividade da artista, uma compreensão entre linguagem e editoração.

Através das ilustrações para $O$ Romanceiro da Inconfidência, Katz ilustra um dos poucos atos de rebeldia da nossa história ocorrida em Minas Gerais no século XVIII, quando a coroa portuguesa respondeu ao movimento da Inconfidência Mineira com austeridade e violência. A artista demonstrou sensibilidade e drama em sua produção, que dialoga intensamente com a narrativa de Cecília Meirelles (CRUZ, in Romanceiros da Inconfidência, caderno artes plásticas, Jornal da Bahia, 1982). 


\subsection{Os cadernos da artista}

Sabemos de longa data que os cadernos de desenhos acompanham os artistas em toda a sua trajetória, principalmente porque guardam anotações conhecidas apenas por eles e que muitas vezes nunca foram divulgados. Segundo Eluf (2011), os cadernos de artistas guardam o pensamento construtivo que revela a direção da sua produção. Eles nos proporcionam uma reflexão sobre o desenho e a relação com as imagens que representam a vida e o mundo.

Segundo o prefácio do livro da Coleção Cadernos de Desenho sobre Katz publicado pela Editora da Universidade de Campinas no ano de 2011, Eluf (2011) afirma que o caderno do artista revela o que está oculto, o desejo do artista que ainda está fechado na intimidade do processo criativo e guardado no bolso. Acredita que estes registros indicam aspectos relevantes sobre o desenho, como uma reação imediata do nosso olhar. As anotações são elaboradas apenas por caneta e representam os estudos que acompanham todos os trabalhos da artista (ELUF, 2011, p. 5).

Eluf (2011) também reconhece que é, através do caderno ou diário de bordo, que o artista materializa a sua inspiração, põe em ordem e constrói o seu pensamento. O seu diário nos mostra como a artista estava voltada tanto para as questões estéticas, como também para a ética, e o quanto estes dois aspectos estão interligados e indivisíveis em sua vida. Nos seus cadernos, traz de modo livre, sem preocupação com o começo, o meio e o fim as ideias soltas, despretensiosas sobre a sua pesquisa processual. Este diário nos proporciona conhecer a experiência da artista no seu métier que, através de seus registros, divide a sua experiência conosco e passamos a nos encantar com o seu mundo revelado. O caderno de bolso de Katz apresenta a dimensão humana da sua obra, no seu tempo. A artista agiu sobre as várias gerações de seus alunos, seja através do seu ensino da arte e/ou através da sua própria produção artística (Ibidem, p. 5-13).

Durante o processo criativo de Renina Katz, verificamos com frequência uma vontade de registrar o seu próprio trabalho através de anotações, desenhos em cadernos e rabiscos em várias provas de impressão. Há, em seu trabalho, uma relação íntima entre imagem e narrativa, que pode ser percebida nas muitas gravuras de sua autoria (Cf. ELUF, in KATZ, 2011, p. 1112).

\subsection{A cor em Katz}

Katz fez a sua última gravura em madeira em 1956, passou a fazer pintura a óleo e vinil e logo foi para a serigrafia, onde realizou um estudo sobre a cor. Nesse período, ela utilizou o 
desenho como estudo do espaço bidimensional. Através deste percurso, a artista passou da serigrafia para as propostas mais abertas, como a litografia, momento no qual começou a lidar com processos mais complexos que envolviam conhecimentos sobre as reações químicas em superfícies planas. Afirma que, com a litografia, se dedicou mais ao desenho e se manteve completamente desvinculada dos desenhos da fase figurativa. Incluiu a cor em seu trabalho como fizera durante um período em que estudava na Escola Nacional de Belas Artes. A artista refere-se à litografia como uma das expressões mais pictóricas das técnicas, depois das gravuras japonesas, que segundo ela chegam a possuir quarenta cores. Segundo a artista, a técnica da litografia foi a que mais liberdade lhe proporcionou. Neste período, se entrega inteiramente às suas experiências com a litografia e produz muitas gravuras com paisagens apreendidas pela memória, pelo mundo dos sonhos onde podemos verificar um toque do surrealismo (BITTENCOURT, 2008, p. 29-30).

Somente mais tarde se dedica a aquarela e se empolga com as cores e as transparências que invadem seus trabalhos deste período. As cores e as transparências se fixam nas estruturas formais de sua construção. Mantém, assim, uma intermediação com a paisagem que agora assume um caráter surrealista e fala da relação do homem com o mundo de forma onírica, embora continuasse narrando histórias que se passam na sua relação com a natureza. A artista volta o seu olhar para a atmosfera de paisagens imaginárias, representadas pelos seus céus, pelas montanhas, pelos astros, enfim, é um deslumbramento com a natureza, com as suas memórias e com as cores. Segundo Katz, só foi possível alcançar estas percepções através da aquarela. Tudo construído por um encantamento das formas e das cores que, neste momento, surgem efetivamente em sua obra (RIBEIRO, Leo Gilson, Renina Katz. Revista de Bordo Varig, s/d. p. 9-10).

Quando questionada por Jayme Maurício sobre a sua produção em aquarelas em plena época do vídeo e do computador, Katz diz não se sentir anacrônica ao fazê-las neste período. Afirma não acreditar em atrofia do equipamento sensorial humano e que a técnica veio libertar a mão das tarefas mecânicas, para que tragam criatividade. Afirma com sabedoria sobre a experiência: "uso a mão como um instrumento original insubstituível” (MAURÍCIO, Jayme. In Hoje, Renina. Rio de Janeiro, 1975).

Quanto à escolha de seu suporte, a artista demonstra um fascínio encantador sobre o papel, que a acompanha na gravura, nas ilustrações, na aquarela, enfim, não restam dúvidas sobre a sua paixão pelo papel. Valoriza-o incomensuravelmente, com uma postura artística inegável. Queixa-se da qualidade do papel de fabricação nacional e do custo dos importados, 
porém reforça a importância de se trabalhar com materiais de qualidade (Cf. AMARANTE, 1997, p. 29).

A artista utilizou o preto e o branco nas gravuras da Antologia Gráfica porque estas cores atendiam as suas preocupações da época. Segundo Katz, o preto era importante porque é uma cor impactante: o preto não distrai e o vermelho tem força para dar um foco. Lembra o vermelho de Goeldi que, para Katz, representa o grito do artista. Cita $O$ Vermelho e o Negro do início da sua relação com a litografia, além de Cárceres onde aparece o vermelho novamente.

Na trajetória da artista existe uma relação íntima com a cor. Quando começou a estudar a cor, foi buscar informações nas cartas de Van Gogh a Théo, seu irmão e nas anotações de Paul Klee e Cézanne (AMARANTE, 1997, p. 26-27). Ainda buscou informações sobre a cor por meio de observações das obras de Diego Velázquez e dos americanos da década de 1960 e 1970, que chamaram a sua atenção pela forma como utilizavam a cor. (BITTENCOURT, 2008, p.30-31).

Outra característica importante no processo posterior da artista é a relação entre a cor e a transparência que, em sua obra. Segundo a artista, o que fascina na cor são a luz e a transparência que resulta das sobreposições das suas gravuras, por isso a cor de Katz nunca surge empastada, e sim transparente. Katz associou a cor e a transparência e obteve um resultado surpreendente, conseguiu uma superposição de cores na litografia com cinco matrizes e passou a adquirir o triplo nas mudanças cromáticas, expandindo assim a sua expressão (BITTENCOURT, 2008, p.30-31 Na aquarela, Katz realiza um exercício de "interação de cores que crescem de diminuem da intensidade até construírem um discurso pictórico" (ABRAMO, Radha. In As aquarelas de Renina, lindos cristais de luz, Folha de São Paulo, 1984).

Quanto ao uso da cor, a artista comenta, em texto escrito por ela e sem data, sobre como via o uso do preto e branco nas suas gravuras:

(...) quando eu faço uma gravura em preto e branco, a cor está implícita. Afinal, tem luz e sombra. Eu apenas uno as pontas, mas há gradações de luz e sombra. Se for aplicada uma cor, o resultado funciona. É sempre a questão da luz (KATZ, 2007, p. 52). 


\section{CAPÍTULO 3 - ANTOLOGIA GRÁFICA: UM OLHAR SOBRE A GRAVURA DE RENINA KATZ E SUA CRÍTICA}

Bibliófilos e colecionadores de arte contam com um grande livro-objeto que foi organizado por Flávio Motta e graficamente impresso pela Editora Cesar em 1977. O livroobjeto representa um requinte gráfico e conta com a seleção da produção da nossa grande artista gráfica Renina Katz.

Ao conhecer a obra em estudo priorizei o meu olhar sobre ela, procurei desenvolver uma relação de observação de todos os detalhes que compõem as suas gravuras, uma a uma. Observação das linhas, das cores, da estrutura na qual se apoia toda a composição, a perspectiva quando presente, a luz, o escuro, as figuras, as suas relações espaciais individuais e em relação ao conjunto da obra. Resolvi me distanciar dos aspectos preconcebidos de terminologias tradicionais da história da arte. E resolvi, conforme recomendado por Jorge Coli em seu livro Como estudar a arte brasileira do século XIX?, partir para a observação, aguçar a percepção e então proceder às descrições despretensiosas e livres de ideologias, culturas e política (COLI, 2007, p. 9-22).

A obra Antologia Gráfica, segundo a definição do termo, significa seleção de gravuras, na qual se pressupõe a definição de alguns critérios que dirigem esta coletânea. Um dos critérios certamente é o período em que as gravuras foram produzidas: 1948 a 1956. Outro seria a escolha de xilogravuras e linóleos. E outro aspecto que predomina seria o fato de, neste período, a artista estar voltada para a arte do realismo social e, portanto, engajada em uma luta por consciência social e política. Estas gravuras representam a fase inicial na produção da artista. As xilogravuras e linoleogravuras presentes nesse livro-obra narram a situação social, política e econômica que predominou na produção de muitos artistas nacionais e internacionais. Contribuiu, desta forma, para a construção da história da gravura brasileira. Podemos, através dessa obra, verificar também as suas arrojadas especificidades técnicas e temáticas que determinam a sua interação, diálogos possíveis com outros trabalhos artísticos nacionais e internacionais, como veremos a seguir.

A obra forma um texto visual através das suas xilogravuras e linoleogravuras produzidas no período. Esse texto visual é composto por uma coletânea de gravuras, estruturadas em figuras de camponeses, retirantes e favelados. Essas figuras humanas estão representadas por um humanismo vibrante, resultante de construções plásticas, com o uso ou não de suportes em papel, que às vezes são coloridos ou brancos. As linhas de Katz riscam 
caminhos e diversas figuras em suas atividades de trabalho. $\mathrm{O}$ seu desenho é definido por áreas de relevo intercaladas por profundos sulcos sobre a madeira, de onde geralmente surge a luz que vem por trás e define as formas das imagens figurativas num jogo de claros e escuros. Por sua vez, essas imagens são motivadas pela sensibilidade e o conhecimento técnico, resultante da disciplina e da persistência da artista em busca do novo para expressar a sua denúncia social através da arte.

A obra é composta por séries temáticas (Retirantes, Favela, Camponeses, entre outros) que foram organizadas e compiladas na publicação do álbum em 1977, dois anos após a impressão das matrizes. A publicação teve como objetivo reavivar a produção da artista em sua juventude e a reintroduzir no debate artístico e no mercado da arte. Os dados sobre a obra foram retirados das informações contidas no próprio álbum-obra.

O Álbum analisado no presente trabalho teve uma edição única, contendo 45 xilogravuras e linoleogravuras executadas entre 1948 e 1956. Todos os trabalhos encontram-se nomeados e assinados pela artista. Nessa ocasião, imprimiram-se 80 exemplares numerados de 1/80 a 80/80 e 10 exemplares de colaborador marcados de A a J. O exemplar estudado é o H e a impressão é a 80/80.

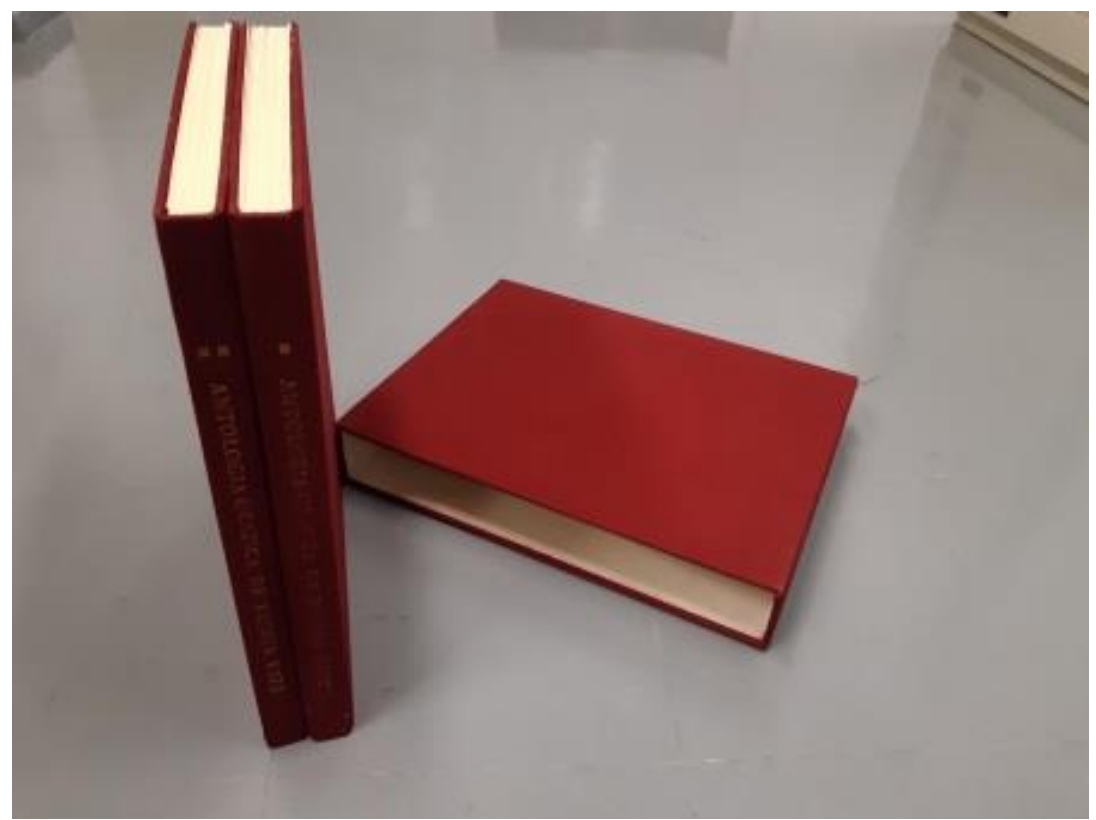

Figura 19 - Renina Katz, Antologia Gráfica, 1948-1956, xilogravuras e linoleogravuras, Fundação Armando Álvares Penteado, São Paulo.

O álbum é composto por uma caixa, que contém dois volumes. Cada volume acondiciona as gravuras em tamanhos variados. As gravuras em estudo foram impressas em papel japonês do tipo mino. O texto foi escrito em Garamond composto e impresso à mão em 
papel Westerprint. A impressão do presente livro foi concluída em 25 de março de 1977, pela Editora Cesar, que mantém todos os direitos. As suas matrizes foram destruídas após a tiragem deste livro.

O impressor das gravuras selecionadas para Antologia Gráfica procurou dar um tratamento cuidadoso para a coletânea. Colocando cada uma delas em passe-partout, de forma que, após esse acondicionamento, cada folha passou a apresentar um tamanho de 41,3 x $32 \mathrm{~cm}$. As folhas soltas e com as suas respectivas gravuras foram acondicionadas em dois volumes com capas duras. Para guardar os dois volumes, foi confeccionada uma caixa. Estes dois volumes e a caixa foram cobertos por tecido $100 \%$ algodão na cor vermelha. Em suas lombadas, ambos os livros foram identificados pelo nome da obra e seu respectivo volume.

O conjunto representa um livro-objeto, que se revela passo a passo durante a sua observação e ao manuseá-lo livremente. Suas páginas são as próprias gravuras que se encontram soltas dentro de cada volume e que por sua vez são envolvidas pelas capas. Além de encontrarem-se soltas dentro de cada volume, as gravuras desse período não estão datadas, o que confere a liberdade para reordená-las, criando outra possibilidade de leitura e diálogos dentro e fora do livro-objeto. A Antologia Gráfica se mantém atual, pois ainda vivemos a problemática da fome, dos movimentos migratórios, da exploração da força de trabalho, da violência contra a mulher e da segregação de classes sociais. A artista soube retratar com detalhes estes conteúdos temáticos em construções espaciais bem estruturadas. Katz percorreu com as suas linhas entre o realismo social, o expressionismo alemão e o lirismo.

Nas gravuras contidas na obra em estudo, é muito frequente a impressão ora em papel japonês colorido e/ou gravadas com outras cores. Há, também, as impressas em preto. A utilização das cores nas impressões gráficas dessa obra são em geral cores únicas e diferentes para cada gravura. As cores, quando presentes, seguem critérios formais e expressivos. Percebemos que elas mantêm alguma relação com o tema e/ou a mensagem da gravura para a qual foram selecionadas. Logo, elas encontram-se a serviço da plasticidade das formas e dos temas abordados, dando intensidade e expressividade às gravuras. Katz fez uma escolha criteriosa da cor que ilustra cada gravura colorida das séries que compõem a sua Antologia Gráfica. Podemos verificar o verde nas gravuras sobre as atividades no campo, o uso do ocre está muito presente nas imagens sobre a favela e assim procede com as demais gravuras. O uso de cores nessa obra diferencia esta coletânea das primeiras tiragens avulsas que foram impressas somente em preto. Essas tiragens em preto representam recortes da obra e encontram-se individualmente em alguns acervos museológicos. 
A obra é acompanhada por um texto de Flávio Motta de 1972 sobre Antologia Gráfica e sobre o processo criativo do período de 1948 a 1956 de Katz. O escritor nos indica alguns aspectos relevantes sobre as gravuras selecionadas para compor o livro-objeto. Estas considerações são voltadas para a construção das gravuras, para o olhar da artista sobre o homem e o seu meio e o seu compromisso ético e social na construção das imagens que integram a Antologia Gráfica. A partir desses aspectos, que considero relevantes na obra, trago alguns trechos do texto seguidos por gravuras em busca de uma interação entre trechos do texto de Flávio Motta e a gravura de Katz. Essa interação pode ser visualizada através das descrições que revelam o conhecimento sobre a obra e a artista pelo bibliófilo.

Há sempre uma razão presente nestas gravuras mais antigas, agora reunidas numa nova edição (...). O povo sofrido, as crianças abandonadas, os lavradores, a guerra, a fome, a injustiça, os retirantes, tudo isso emergia do mesmo clima dos anos 40/50 (MOTTA, 1972).

A linguagem utilizada nessa obra foi uma das mais convencionais, papel impresso a mão, xilogravura e linoleogravura. De não convencional, há apenas o fato de termos que manusear as suas folhas soltas, sem regras ordinárias a observar.

As gravuras presentes na obra mostram a vida cotidiana de retirantes, trabalhadores, mulheres e homens em árduas atividades e crianças. Tudo construído com determinação e realismo. Podemos verificar abaixo a situação que predominava no cenário brasileiro nos anos de 1948 a 1956. Esse contexto social foi retratado em Antologia Gráfica, conforme podemos verificar nas seguintes gravuras da série Retirantes:

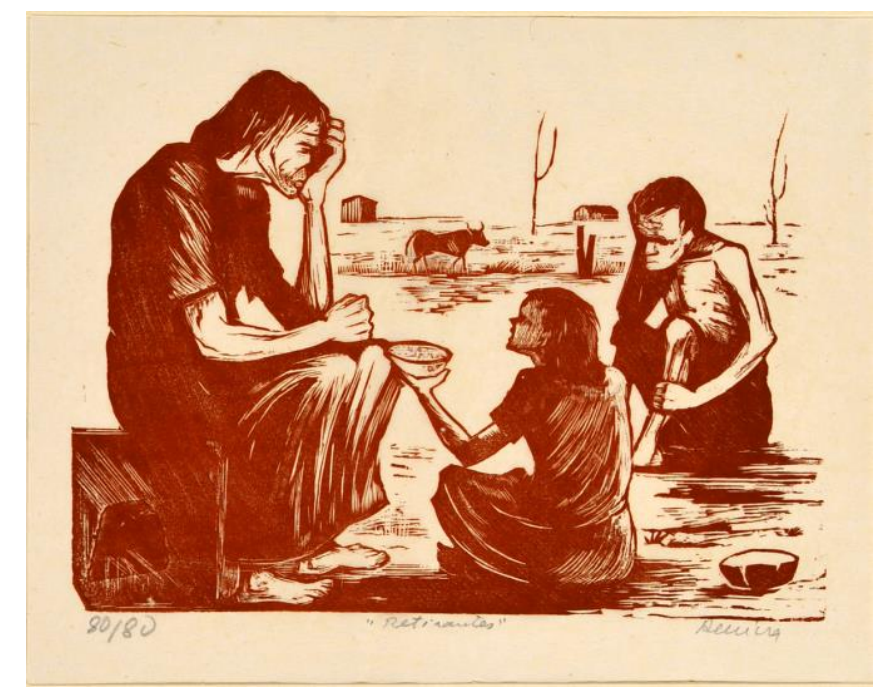

Figura 20 - Renina Katz, Retirantes, 1948-1956, xilogravura, Fundação Armando Álvares Penteado, São Paulo, $17,3 \times 22 \mathrm{~cm}$. 


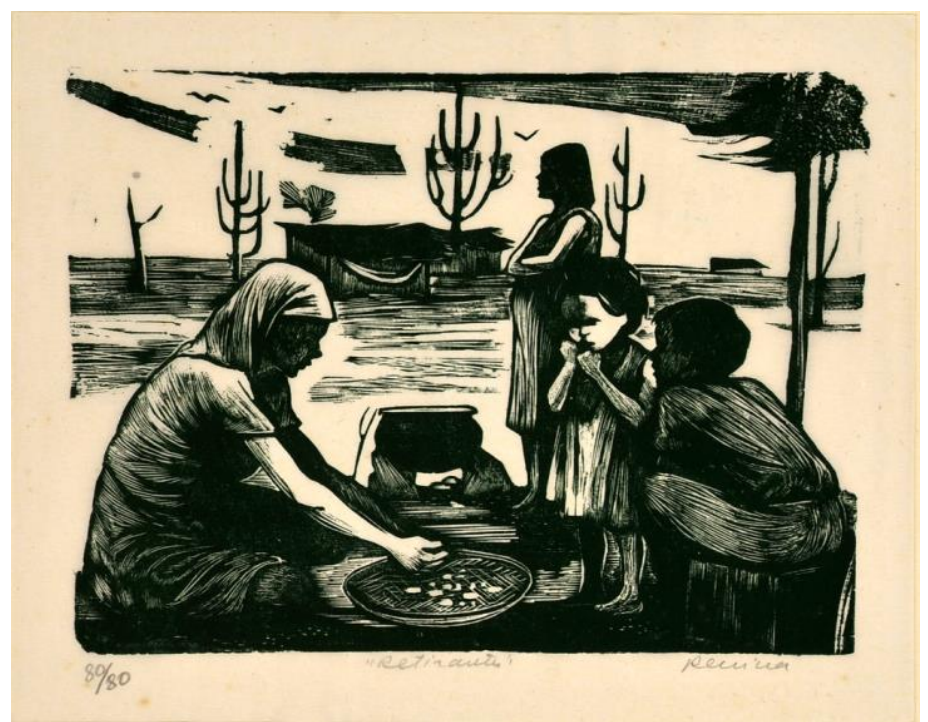

Figura 21 - Renina Katz, Retirantes, 1948-1956, xilogravura, Fundação Armando Álvares Penteado, São Paulo, $17,6 \times 22,6 \mathrm{~cm}$.

A representação da mulher trabalhadora com crianças ocorre com frequência em cenas que predomina a procura por recursos para suprir a fome ou por abrigo em noites de frio nas ruas das grandes cidades. A seguir, trecho de Motta (1972):

Aqueles pormenores que a artista colocava para designar cada figura, cada árvore,
cada pedra, já continha um obstinado fervor ao trabalho, o que levaria e,
posteriormente, a uma "imagem-conceito" mais nítida. Mas, assim mesmo, pareciam
conservar o lirismo, entre as asperezas dos caminhos dos "motivos" que a artista
percorria.

Os caminhos mencionados por Motta são caminhos percorridos diariamente nos afazeres das mulheres faveladas em intensos movimentos em busca de recursos para sua sobrevivência e de seus filhos. Katz traça caminhos penosos através de linhas ásperas e manchas escuras e/ou cores intensas, como podemos ver em uma das gravuras abaixo da série Favela: 


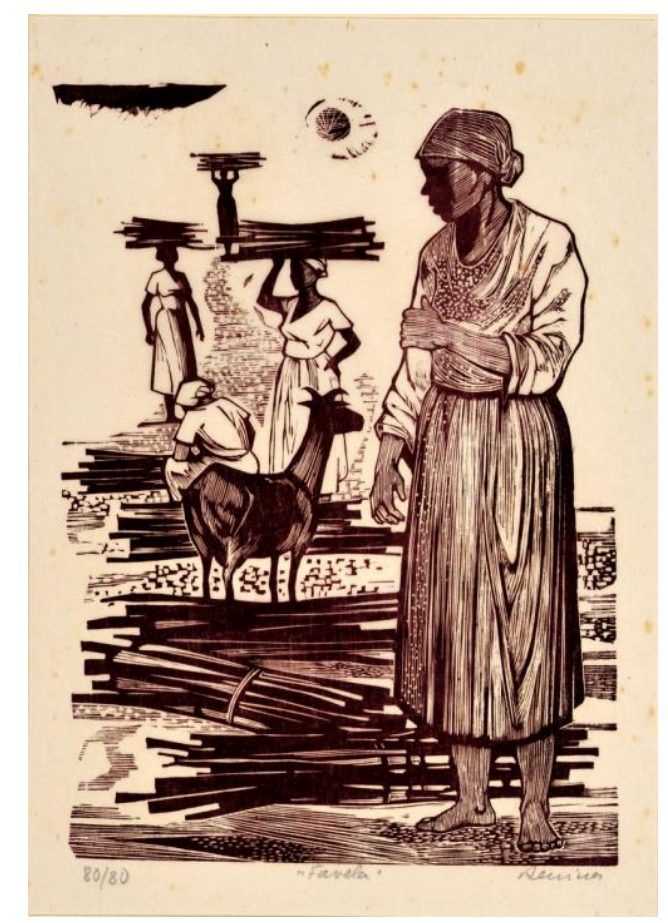

Figura 22 - Renina Katz, Favela, 1948-1956, xilogravura, Fundação Armando Álvares Penteado, São Paulo, 28,2 $\mathrm{x} 19,7 \mathrm{~cm}$.

As gravuras sobre a vida das mulheres em Favela revelam uma precariedade social tratada com naturalidade e representada pelo trabalho árduo desenvolvido por mulheres, em que podemos ver constantemente a presença de crianças e animais convivendo no mesmo espaço e caminhando juntos. As gravuras da série Favela revelam uma composição compacta, centrada e trabalhada em uma estrutura central e depois acrescida de outras imagens complementares que formam uma unidade. Segundo Aracy Amaral (1984, p. 178).

O tema sobre a maternidade se encontra presente em Antologia Gráfica através de várias gravuras, como podemos ver nas séries Retirantes, Favela e em outras gravuras líricas como Quintal. Na série Favela, a maternidade é retratada sempre através de imagens que mostram as mulheres e as crianças no mesmo espaço, onde predomina a mensagem do trabalho. Nas gravuras sobre os retirantes, a artista representa a maternidade com sentimentalismo profundo, como podemos observar nas gravuras seguintes: 


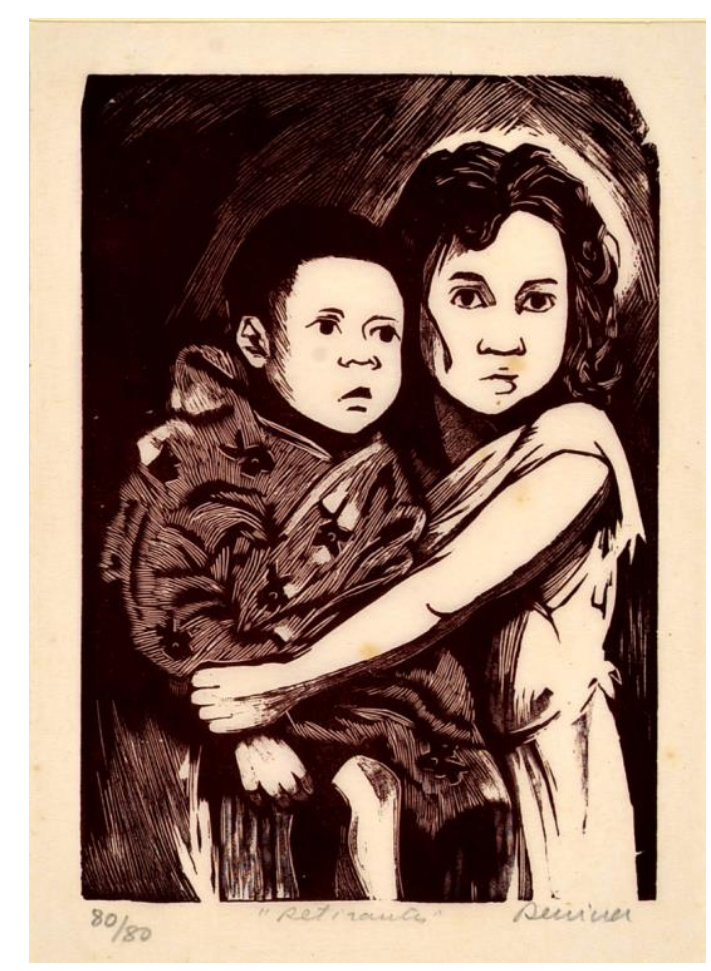

Figura 23 - Renina Katz, Retirantes, 1948-1956, xilogravura, Fundação Armando Álvares Penteado, São Paulo, 19,6 x 13,6 cm.

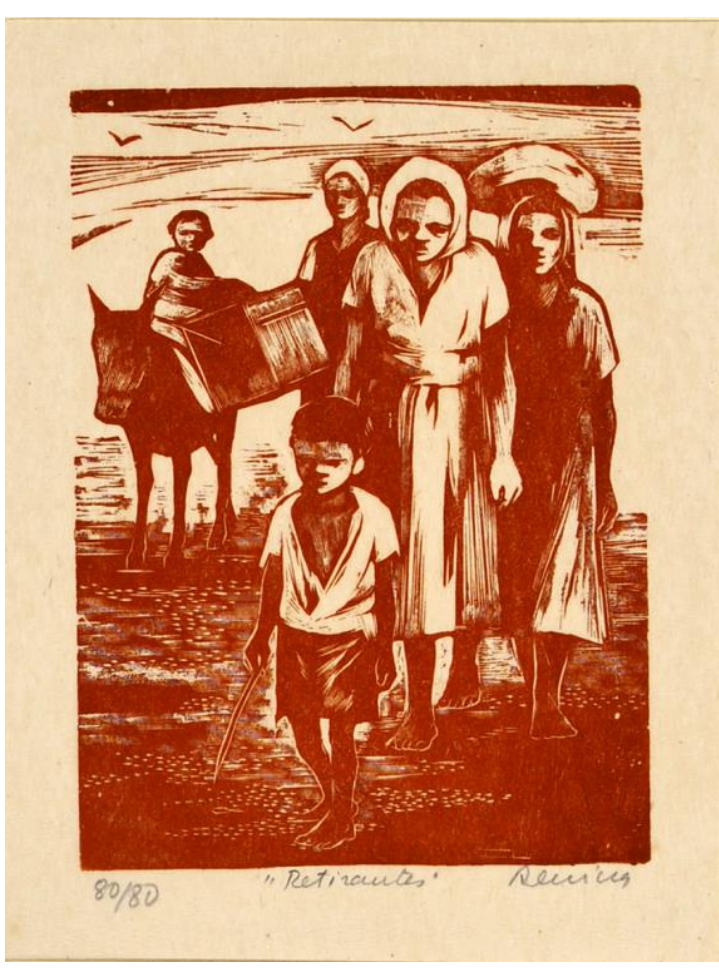

Figura 24 - Renina Katz, Retirantes, 1948-1956, xilogravura, Fundação Armando Álvares Penteado, São Paulo, 17,4 x 13,2 cm.

Na figura 23, os detalhes dos tecidos das roupas e drapeados podem ser visualizados na construção do manto que cobre a criança e no cabelo ondulado da mulher que segura a criança.

No processo criativo da artista em Antologia Gráfica, as gravuras reforçam o pensamento de Goethe: "a ideia na imagem permanece infinitamente ativa e inexaurível". Na ocasião da exposição sobre os seus trabalhos doados ao Museu Nacional de Belas Artes em 2007, o curador Sérgio Pizoli (2006, p. 25) teria comentado que:

Através da obra em estudo Renina Katz nos mostra como o seu processo criativo ocorreu, assim como uma "escrita contínua, múltipla, ela atualiza o requinte gráfico do seu trabalho a cada nova paisagem, secretamente figurativa e intensamente livre".

\subsection{Temas das gravuras: uma representação da sociedade}

Os temas das xilogravuras e linóleogravuras estudados são em sua maior parte compostos por séries de gravuras sobre favela, retirantes e camponeses. Para compor essas séries, Renina Katz desenhava nos seus sábados e domingos e gravava, principalmente, em madeira as cenas que ilustram as condições de vida das pessoas que viviam em favela e/ou as que chegavam à Estação do Norte em busca de uma nova possibilidade de vida. Gravou imagens de trabalhadores em suas atividades agropecuárias, como a pesca, as salinas, os operários da 
construção civil, mulheres faveladas e suas crianças. Todas essas gravuras denunciam as situações precárias de subsistência, fome, miséria, frio em um país em transição. Em suas gravuras, podemos visualizar também os aspectos culturais do país, como as brincadeiras infantis, conversas entre mulheres em cenários domésticos ou nas favelas, como as lavadeiras, animais, barracos, transportes coletivos, algumas estruturas de ferro nas grandes cidades que denunciam a modernidade e ao mesmo tempo a seca. Essas são as ambiências que o olhar, a linha e a gravura da artista revelam. Os temas sobre o realismo social predominam no álbum e narram sobre a vida dos retirantes, dos camponeses, camponesas e faveladas.

A arte de Renina nos identifica com as situações expostas através da empatia que nos causa e desperta os nossos sentimentos perante as suas imagens. O desenho nos leva a este caminho. $\mathrm{O}$ desenho dá forma e humanidade às imagens que constroem esta grande narrativa dos dez anos de produção da artista. A linha de Renina Katz apresenta diversos momentos em sua produção. Inicialmente, na época de Escola Nacional de Belas Artes, se apresentava delicadamente fluida e singela. Podemos perceber um quê de lírico na construção de suas gravuras iniciais, como exemplo cito Maternidade de 1950, que foi exposta em uma mostra organizada pelos seus alunos no Rio de Janeiro. Nelas percebemos também um intenso esforço em busca da representação do mundo dos deserdados através de um traço que se move com determinação e define as formas simples e reveladoras de necessidades.

Renina olha para as mulheres, para as crianças, homens e animais e para alguns elementos que os circulam na construção de sua imagética. $O$ foco de sua investigação é o nordestino, operário, vida nas favelas e rotinas de trabalho no campo, nas cidades, acrescidos pela miséria, marginalização, força de trabalho e condições precárias de sobrevivência. Podemos verificar que, na série Favela, o olhar de Renina encontra-se totalmente para a imagem da mulher. Em Retirantes, as figuras são representativas da classe operária, embora apresente imagem de mulheres em seus trabalhos intensos. Nas gravuras da série Camponeses, também podemos verificar a atividade agrícola sendo desenvolvida por ambos os sexos. Percebe-se, assim, que a imagem da mulher é muito recorrente na produção das gravuras que compõem a obra e que a artista a representa como protagonista em todas as séries presentes em Antologia Gráfica. Nas demais gravuras, a presença feminina dialoga com algumas narrativas nacionais ou mesmo fala da vida cotidiana nas grandes cidades nacionais. 


\subsection{Gravuras livres}

Em Antologia Gráfica é possível encontrar algumas gravuras com linhas simplificadas e que correm livremente sobre o papel. Elas são Quintal, Florista, Parque, Pescador e Pau de sebo. Essas gravuras representam uma menor quantidade dentro da obra e apresentam um toque de graciosidade à Antologia gráfica, talvez por nos remeter as memórias da vida nos trópicos.

As gravuras Florista e Quintal são construídas com imagens bem definidas por linhas finas, fluidas, suaves e em poucos planos. Em Florista há a representação simplificada de uma mulher vendendo flores que nos faz lembrar a florista de Charles Chaplin Em Tempos modernos.

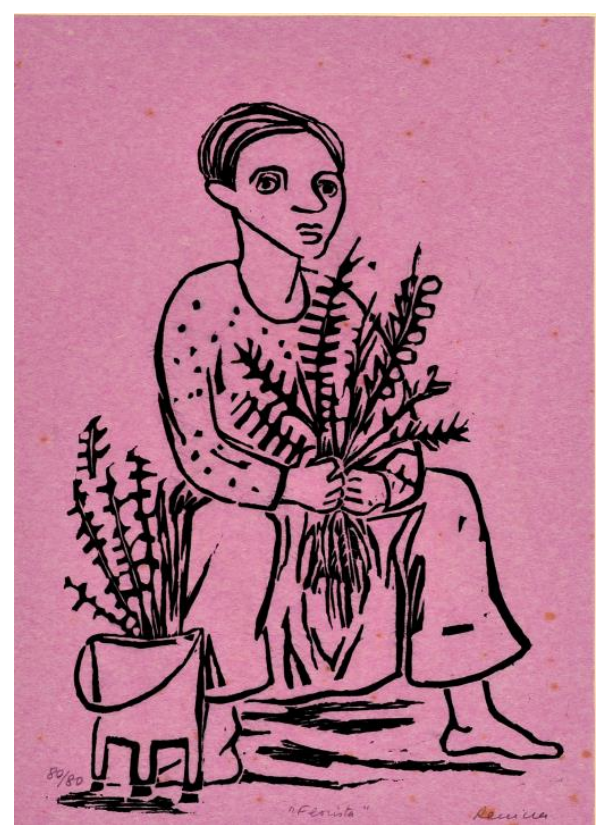

Figura 25 - Renina Katz, Florista, 1948-1956, xilogravura, Fundação Armando Álvares Penteado, São Paulo, 31 $\mathrm{x} 21,5 \mathrm{~cm}$.

Em Quintal, estão presentes cinco mulheres sentadas em volta de uma mesa, comendo e conversando. A situação exposta lembra um momento de descontração. Logo, estas gravuras parecem um intervalo entre as que compõem as grandes séries dentro do álbum. Florista foi impressa em papel pigmentado em rosa e impresso em vinho. 


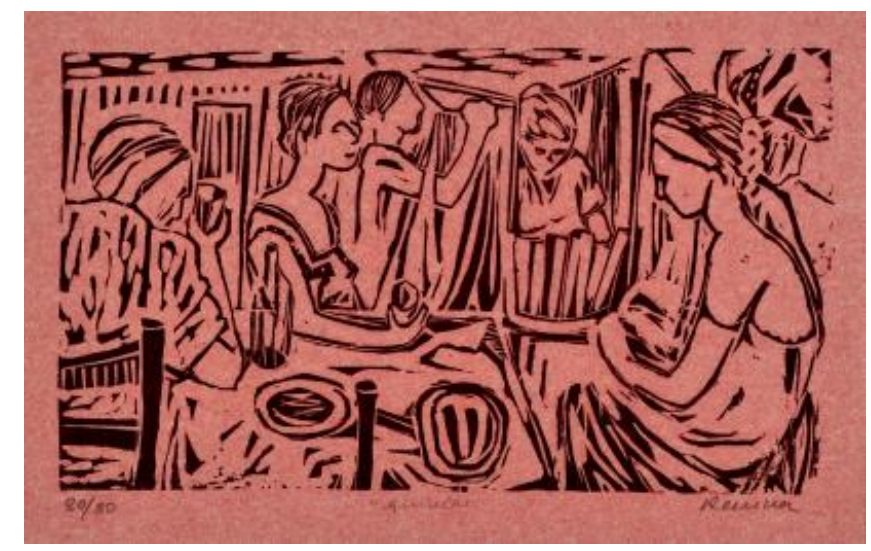

Figura 26 - Renina Katz, Quintal, 1948-1956, xilogravura, Fundação Armando Álvares Penteado, São Paulo, $17,2 \times 27,2 \mathrm{~cm}$

Em Morte no Laranjal, podemos visualizar, no primeiro plano, muitos elementos compondo a cena, tais como: árvores carregadas de frutos e folhas, cesta virada e frutas espalhadas ao chão, inclusive o corpo de uma mulher caído. As laranjas presentes na gravura nos remetem à fertilidade da terra como também da mulher, que é violentada em sua juventude. As formas do corpo são sensuais e poéticas, os seus seios assemelham-se às laranjas. Morte no Laranjal não pertence a nenhuma das séries, mas compõe a Antologia Gráfica. Esta gravura faz parte de oito linoleogravuras que ilustraram o livro de Jorge Amado, Subterrâneos da Liberdade. Segundo Simone (2004, p. 204), Morte no Laranjal dialoga com a gravura Estupro, do ciclo A Guerra dos Camponeses de Kollwitz. A gravura de Kollwitz retrata o realismo social onde a violência contra a mulher é representada com intenso realismo. Esse diálogo se dá pela temática da violência contra a mulher trabalhadora, representada pela camponesa, como pelas formas de construções estruturais presentes nas duas composições.

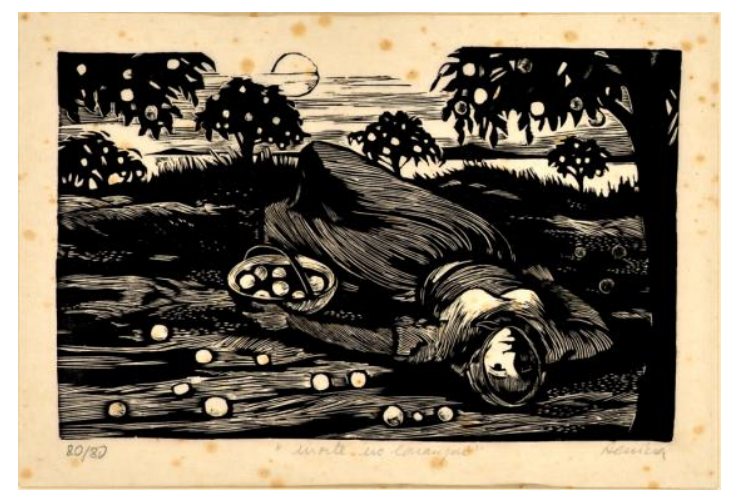

Figura 27 - Renina Katz, Morte no Laranjal, 19481956, linóleogravura, Fundação Armando Álvares Penteado, São Paulo, 16,7 x 24,6 cm.

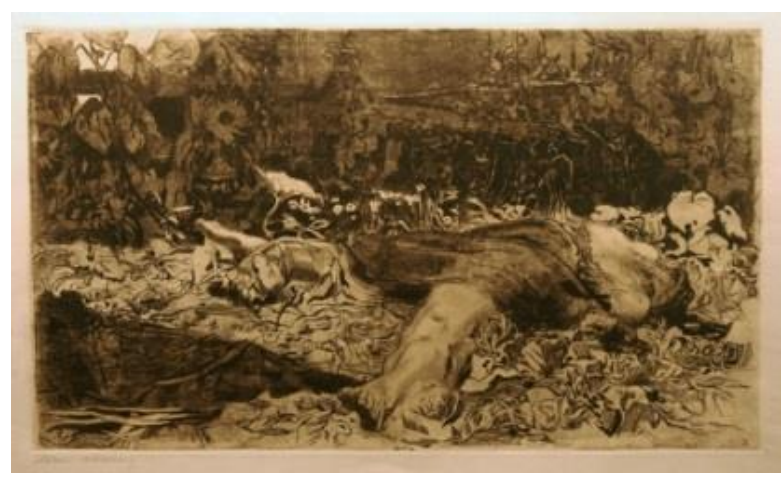

Figura 28 - Käthe Kollwitz, Estupro, gravura em águaforte e verniz mole, 30.8 x $52.8 \mathrm{~cm}, 1907$. 
Consta, na obra Antologia Gráfica, a presença de dois retratos. Um deles representa a figura de um jovem, cuja gravura se chama Zé, e o outro se refere à imagem de uma mulher, intitulado Mulata. Neles podemos perceber as influências de Leskochek, principalmente quando vemos os retratos que o artista desenvolveu para os Irmãos Karamazov. São duas xilogravuras escuras com poucos rasgos sobre a madeira, construídas por linhas precisas, controladas ao extremo, repletas de expressividade, ambientadas na escuridão de interiores que são iluminadas em suas faces, pescoço e tronco pela retirada da madeira através de sulcos. Estes retratos representam tipos nacionais e sensíveis. Katz retrata também a mulata como um tipo nacional.

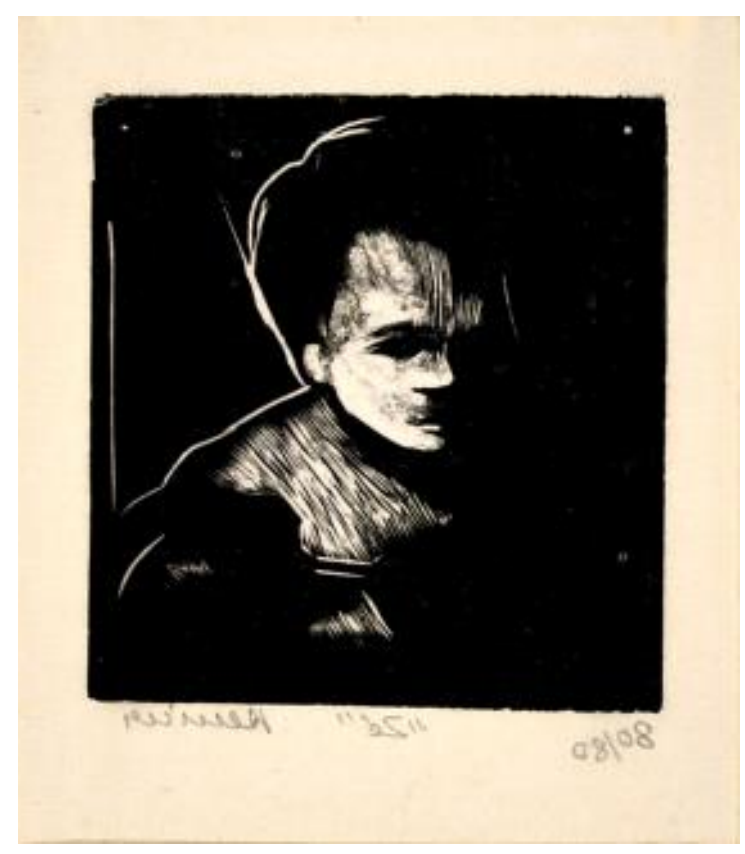

Figura 29 - Renina Katz, Zé, 1948-1956, xilogravura, Fundação Armando Álvares Penteado, São Paulo, $11,2 \times 9,8 \mathrm{~cm}$.

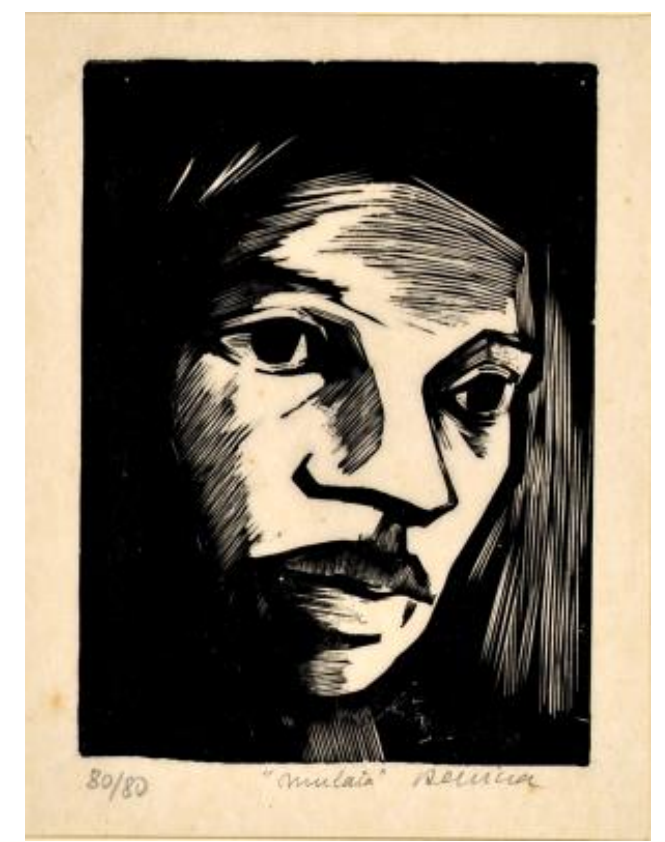

Figura 30 - Renina Katz, Mulata, 1948-1956, xilogravura, Fundação Armando Álvares Penteado, São Paulo, 17 x 12,9 cm.

É possível também verificarmos no seu conjunto a xilogravura intitulada por Pau de Sebo, onde são vistos meninos brincando em um pau de sebo, situação está rara na obra. Esta brincadeira faz parte do repertório cultural das festas juninas em nosso país. É uma cena de brincadeira que consiste em subir num alto mastro de madeira com o objetivo de alcançar um prêmio colocado no topo. A gravura é construída na vertical e em preto. Nela podemos verificar o rigor técnico da artista através da utilização de diversas texturas que definem as imagens e os planos. Nessa construção, estão presentes delicadeza e apuro técnico. A estrutura central da gravura é dada pela construção das imagens dos meninos subindo o tronco de uma árvore 
ensebado e situado na parte central da gravura. Os demais elementos são acrescentados a partir da imagem central. A sua composição vertical lembra a das gravuras japonesas.

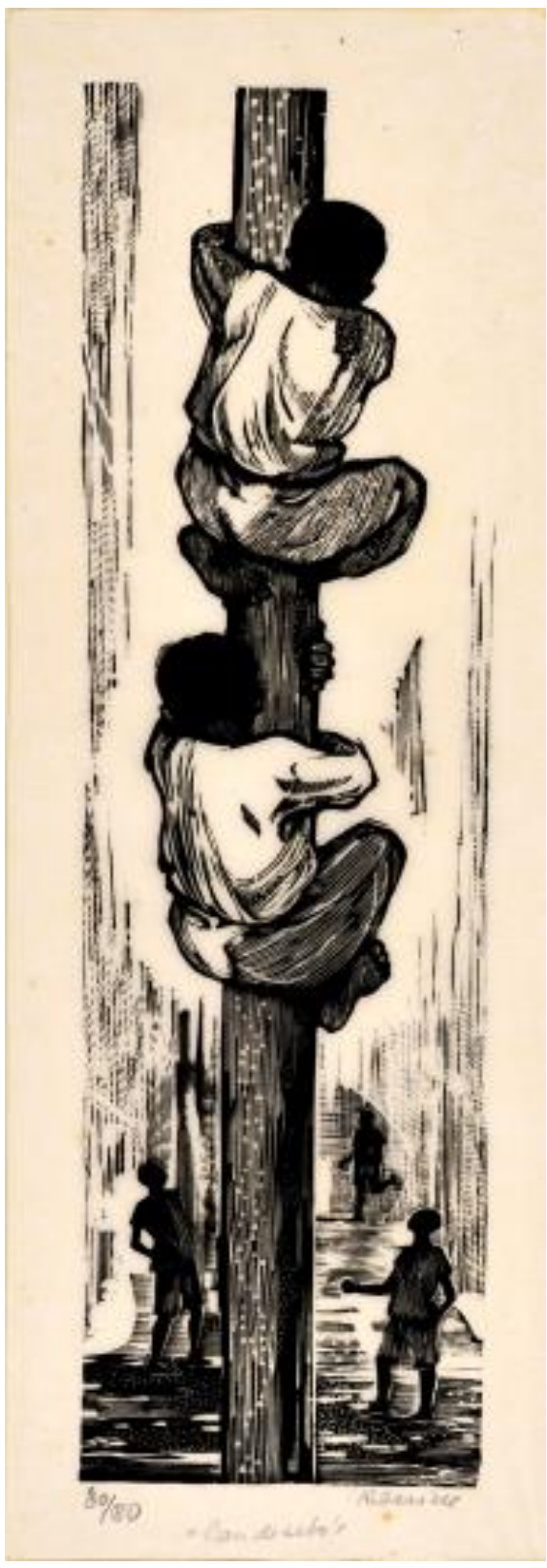

Figura 31 - Renina Katz, Pau de sebo, 1948-1956, xilogravura, Fundação Armando Álvares Penteado, São Paulo, $30,8 \times 10,7 \mathrm{~cm}$.

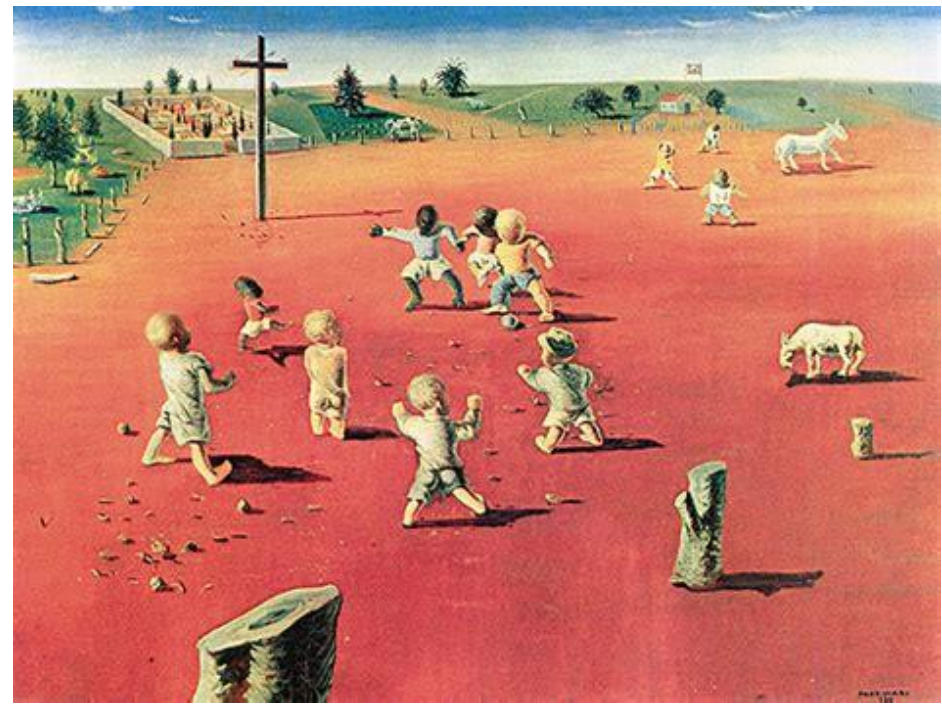

Figura 32 - Cândido Portinari, Futebol, 1935, óleo sobre tela, Coleção Particular, 97 x 1,30 cm.

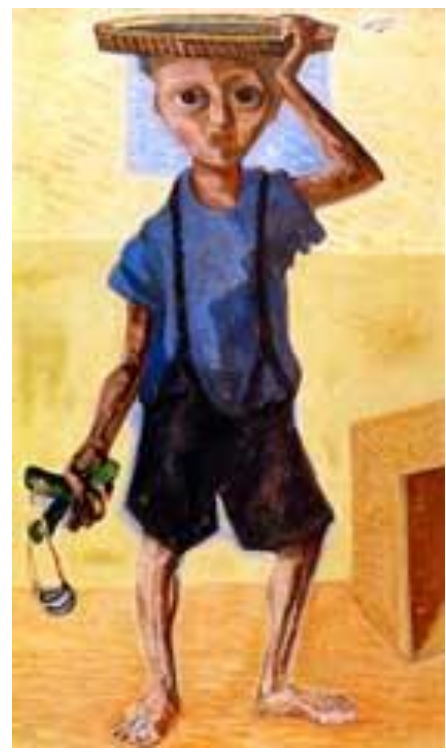

Figura 33 - Cândido Portinari, Menino com estilingue, 1947, óleo sobre tela, $59,5 \mathrm{~cm} \times 103 \mathrm{~cm}$.

O tema de brincadeiras de infância foi bastante representado por Portinari e suas lembranças de Brodosqui em São Paulo através de uma série de óleo sobre tela dos anos de 1940, como Meninos na gangorra, Futebol e Menino com estilingue. 


\subsection{A série de gravuras de trabalhadores do campo e atividades econômicas}

Em Camponesas, é frequente a construção plástica ocorrer na horizontal. A gravura mostra a imensidão dos campos, do horizonte e das matas a serem trabalhadas na plantação ou na colheita. Em geral, nesses cenários há a presença de elementos campesinos nacionais, como plantas nativas, cactos, animais, arados, enxadas, cestos, sacas, casas vistas ao longe, morros e com frequência surgem os céus. Em uma dessas gravuras, podemos ver mulheres plantando e arando a terra com as suas enxadas.

Essa construção ocorre em vários planos, o que dá à gravura uma grande profundidade. A cena acontece ao entardecer, é um pouco escura com o céu indicando o final do dia e pássaros voando em bandos. No terceiro plano, podemos verificar pequenas figuras de mulheres em intenso labor. A sua estruturação foi definida por seis planos, construídos com rasgos, traços precisos e bem distintos. A imagem foi definida com a determinação eloquente dada pela goiva de Katz e se nota o nível de detalhamento e preocupação com a técnica da xilogravura.

A xilogravura apresenta uma riqueza em seus detalhes, inclusive sobre a construção das mãos das mulheres no primeiro e no segundo planos, onde podemos as visualizar uma solução delicada para a sua construção. Mulheres camponesas limpam os matos, preparam a terra a ser plantada. As camponesas se encontram concentradas em suas atividades. Nessas gravuras não é possível visualizarmos os rostos das mulheres, pois estão cobertos por chapéus em todas as seis imagens de mulheres que compõem a cena.

Nas gravuras sobre camponesas, Renina Katz procurou olhar para o realismo francês, especialmente sobre a produção de Jean-François Millet. Millet e Courbet são os precursores do realismo através de suas representações de trabalhadores rurais. A obra de Millet foi uma resposta à estética romântica de gostos um tanto orientais e exóticos. Ele deu forma à realidade que prevaleceu à sua volta, principalmente das classes trabalhadoras. Seus camponeses geraram polêmicas, por serem considerados líricos, mas sua capacidade de observação é fantástica.

Em Camponesas, Renina dialoga com As respigadeiras de Jean Millet. Seja pelo tema ou por seus aspectos formais, ambas as obras apresentam a mesma estrutura de composição. As respigadeiras de Millet apresentam mulheres concentradas em seus trabalhos de recolher as sobras da colheita dos proprietários da terra, pois o que importa é representar a parte mais vulnerável das classes sociais. Assim como Jean Millet, Renina Katz ocultou os seus rostos para indicar o anonimato e a marginalização em suas representações. Os corpos curvados simbolizam o trabalho rotineiro e difícil (GOMBRICH, 2012, p. 508-512). 


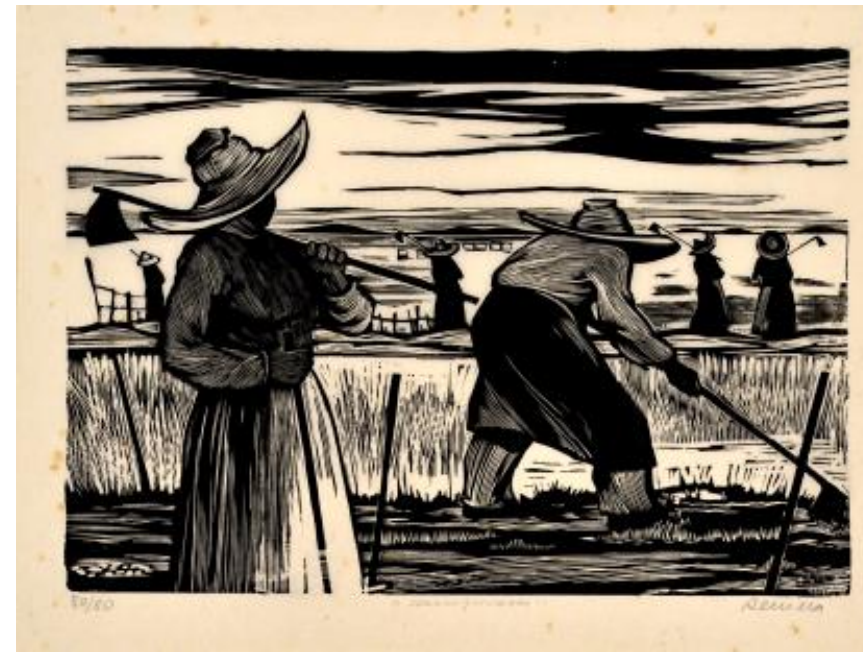

Figura 34 - Renina Katz, Camponesas, 1948-1956, xilogravura, Fundação Armando Álvares Penteado, São Paulo, 19,3 x 16,8 cm.

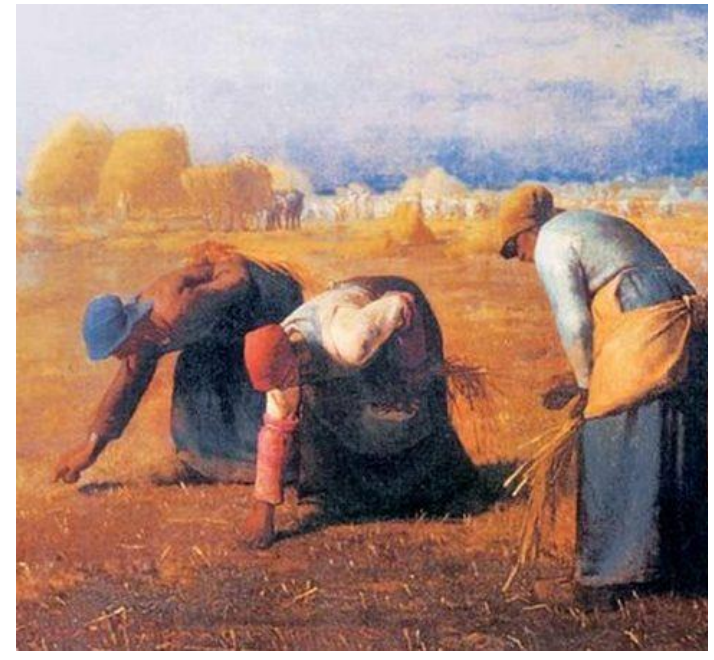

Figura 35 - Jean-François Millet, As respigadeiras, 1857, óleo sobre tela, 83, 8 x 111 $\mathrm{cm}$, Museu D’Orsay, Paris.

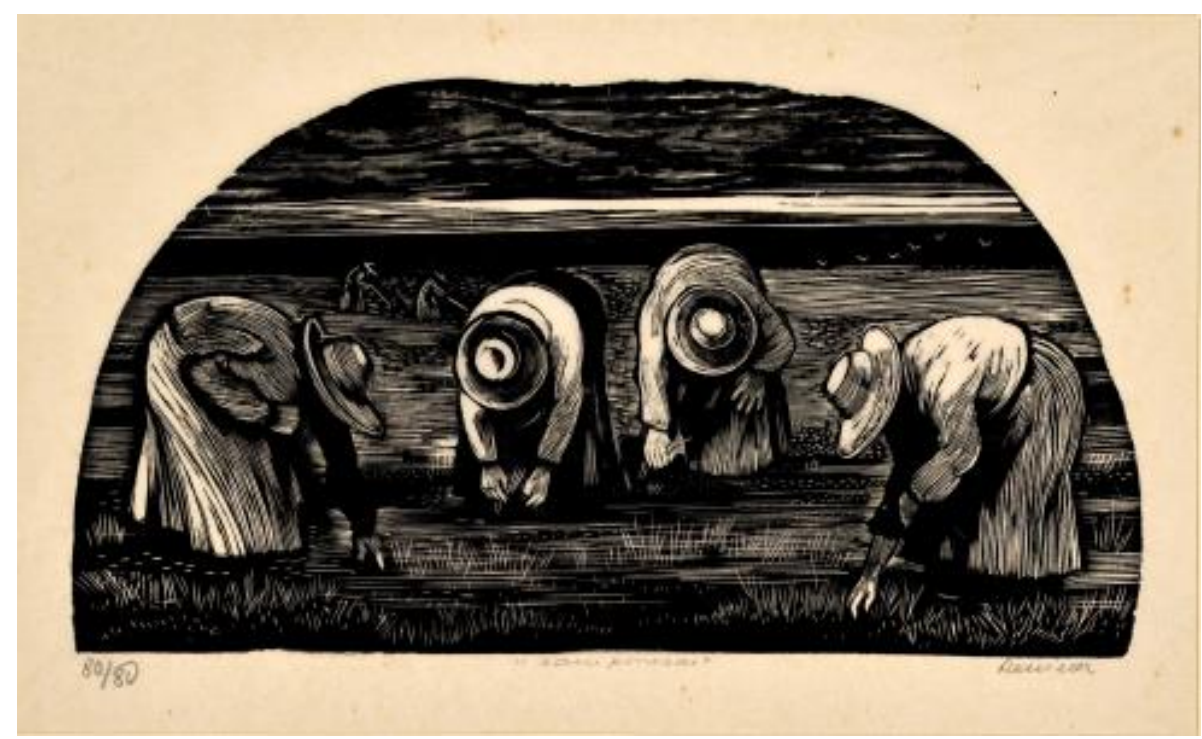

Figura 36 - Renina Katz, Camponesas, 1948-1956, xilogravura, Fundação Armando Álvares Penteado, São Paulo, 18,7 x $30,9 \mathrm{~cm}$.

A gravura Pescadores, em papel japonês pigmentado em verde e imagens em preto, é composta por vários planos. Podemos verificar nela redes de pescar, cestos, chapéus, barcos, céu em intenso dinamismo, mastros verticais que cortam a cena e contrastam com o seu ondulante e tempestuoso céu. As águas estão em movimento e são navegáveis. Os humildes pescadores estão em suas atividades diárias, seus corpos apresentam uma postura humilde, pois são representados por suas cabeças baixas, olhar de resignação predomina na gravura. O movimento nessa gravura ocorre através da representação das nuvens, da água e das redes dos pescadores. 
A gravura $O$ Barqueiro, impressa em azul, apresenta o movimento gravado através de suas linhas levemente curvas. Ao fundo é possível visualizarmos uma cidade construída por formas geométricas que cria um contraste entre as linhas que formam o horizonte e as águas navegáveis. As demais linhas que formam o pescador, os barcos, as velas, o chapéu do pescador, a água e o céu encontram-se em diálogo e parece nos dar uma sensação de estarmos navegando junto ao barco.

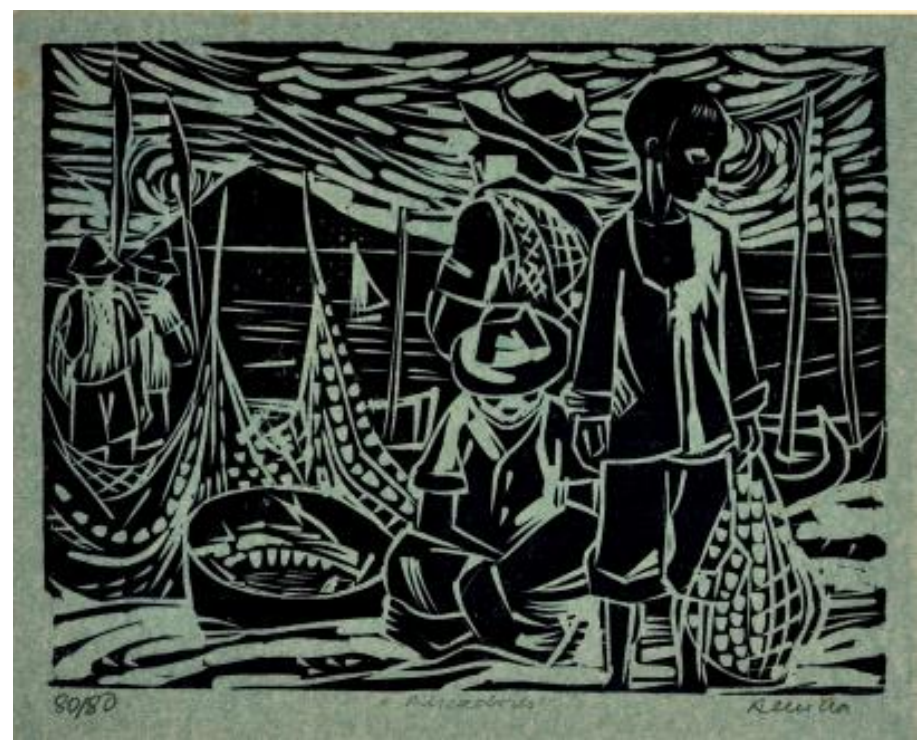

Figura 37 - Renina Katz, Pescadores, 1948-1956, xilogravura, Fundação Armando Álvares Penteado, São Paulo, $19 \times 23,7 \mathrm{~cm}$.

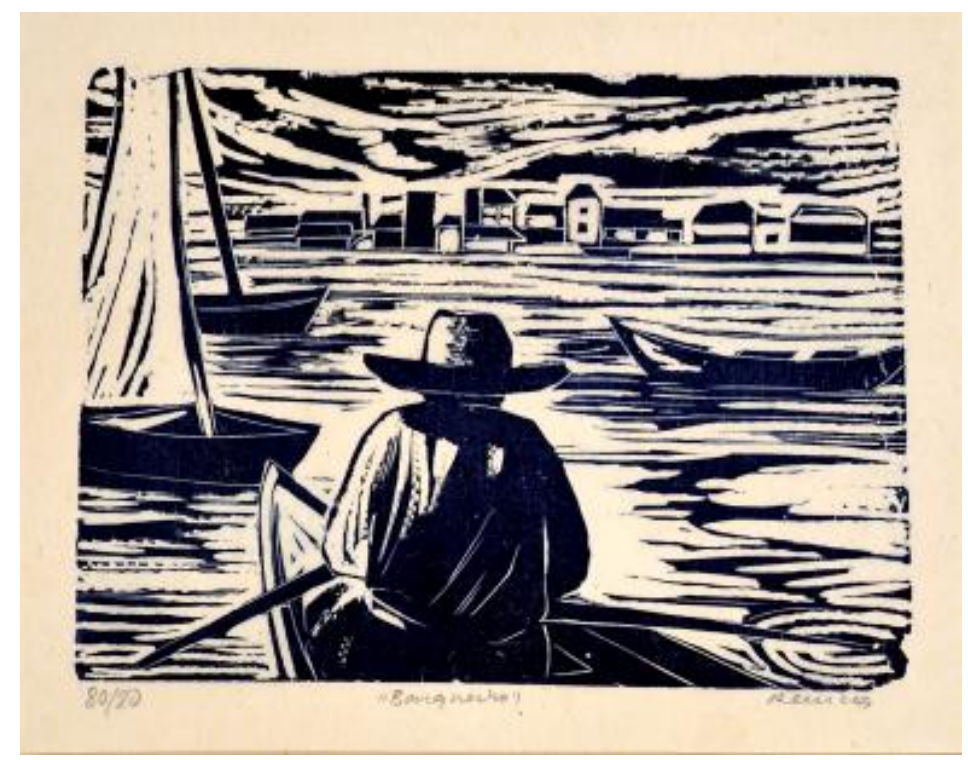

Figura 38 - Renina Katz, Barqueiro, 1948-1956, xilogravura, Fundação Armando Álvares Penteado, São Paulo, $17,7 \times 22,7 \mathrm{~cm}$. 
Podemos destacar, ainda, as gravuras Trabalhadores e Campo, nas quais homens trabalham na construção civil e no campo. Vemos carrinhos de mão, picaretas, pedras, pás e ao fundo uma paisagem com árvores sem folhas, reforçando a caráter austero da atividade civil. As linhas que definem os corpos criam um contraste com as que constroem a arquitetura do espaço. A gravura foi impressa em papel pigmentado em ocre e figuras em preto. Na gravura Campo, vemos os homens e seus instrumentos de trabalho, e ela nos mostra um homem prestes a sua ação com uma foice. Aqui as figuras são construídas como na obra Lavrador de Portinari, onde corpos volumosos são vistos em campos de trabalho, tanto na construção civil, como nos campos de produção agrícolas.

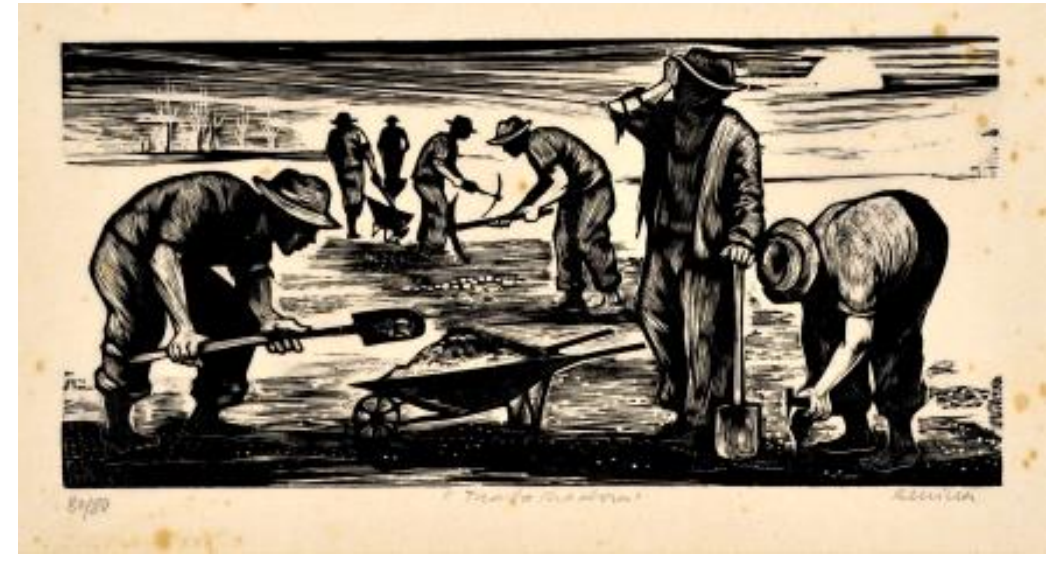

Figura 39 - Renina Katz, Trabalhadores, 1948-1956, xilogravura, Fundação Armando Álvares Penteado, São Paulo, 16,2 x $30 \mathrm{~cm}$.

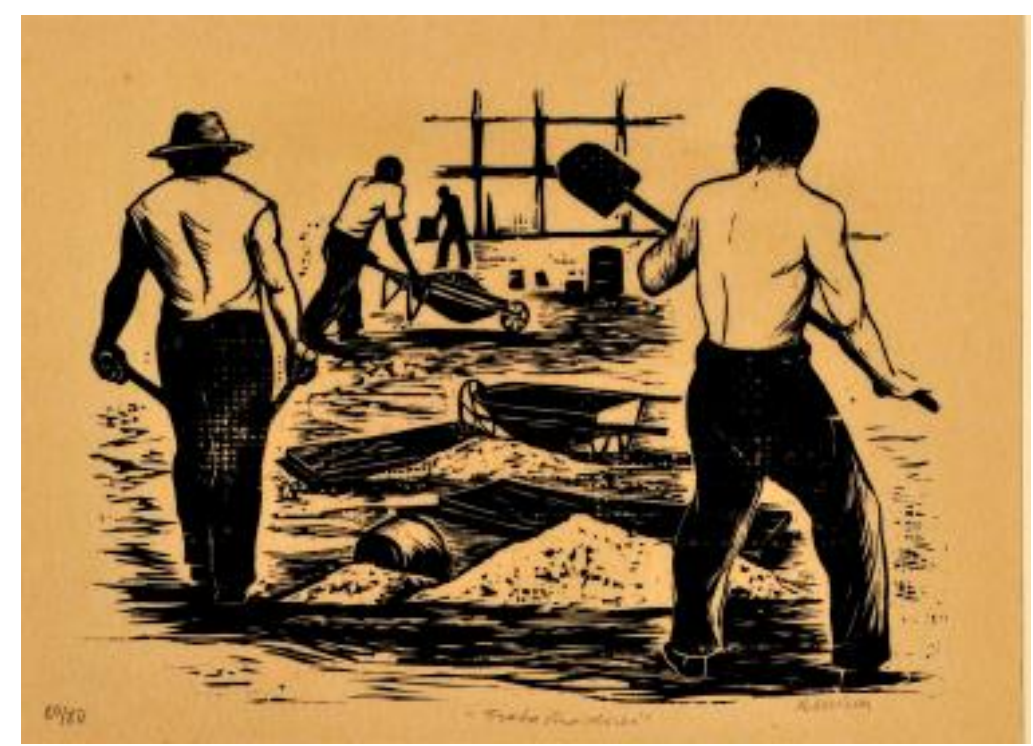

Figura 40 - Renina Katz, Trabalhadores, 1948-1956, xilogravura, Fundação Armando Álvares Penteado, São Paulo, 22,3 x 30, $6 \mathrm{~cm}$. 


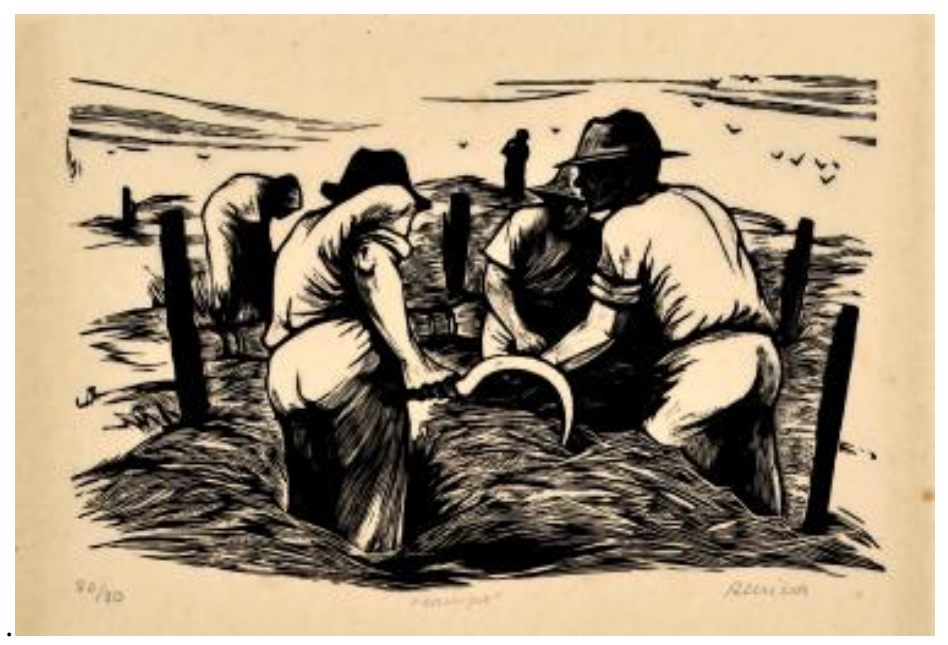

Figura 41 - Renina Katz, Campo, 1948-1956, xilogravura, Fundação Armando Álvares Penteado, São Paulo, $19,3 \times 28,7 \mathrm{~cm}$.

\subsection{Gravuras com cenas urbanas}

Assim como outros artistas, Renina Katz gravou cenas da cidade e as imprimiu em preto. São frequentes as gravuras em que a artista representa mulheres, crianças, e outros elementos que eram possíveis de serem encontradas nas cidades modernistas. A gravura Cidade (fig.12) é composta por três planos. No primeiro, encontram-se três árvores e seus galhos são definidos por linhas retas que se interceptam em algum ponto do espaço. Não há presença de folhagem, pois foi cortada propositalmente pelas margens da gravura. $\mathrm{O}$ segundo plano é composto por um chão definido por formas geométricas. No terceiro plano, a artista quis evidenciar a cidade com postes de luz e prédios altos definidos pela geometria das suas formas. Neste período, representar as grandes cidades em crescimento era uma prática recorrente entre os artistas.

\subsection{A série de gravuras sobre o êxodo rural}

A artista se empenha na denúncia social entre os anos de 1948 até 1956, na produção da série Retirantes. A gravura da figura 8 na página 38 foi realizada utilizando a cor verde e a estrutura do desenho foi definida por linhas brancas. A cena lembra a marcha de grupos de imigrantes, famílias com crianças, chegando às terras desconhecidas após longa e cansativa jornada em paus de araras que chegavam a São Paulo diariamente. Rostos com expressões duras, transtornados, olhares vagos que andam em diagonal e em direção ao desconhecido, chegam aos campos de uma fazenda, possível de ser identificada pela porteira que se encontra entreaberta. 
Na série Retirantes, há uma gravura em que há meninos, homens e animais embaixo de barracões de palha, mostrando as condições de moradia a que estavam expostos sobre o chão de terra batido. Esta gravura foi impressa em cor vinho. Com o mesmo título, há outra em azul, mostrando homens carregando fardos pesados sobre os ombros e outros em suas cabeças. Ao fundo, há um grande arco que forma um grande portão aberto. A luz de Renina Katz surge por trás dessas figuras e invade o ambiente escuro de intenso trabalho braçal. Este ambiente é composto por uma arquitetura que lembra galões ou armazéns, espaços internos utilizados para o armazenamento de produtos agrícolas, muito comuns na plantação de café. Há a figura de uma mulher no canto da composição, a qual se encontra em atividade, juntando as suas coisas ou lavando. Essa composição dialoga com Café de Portinari, como podemos ver abaixo.

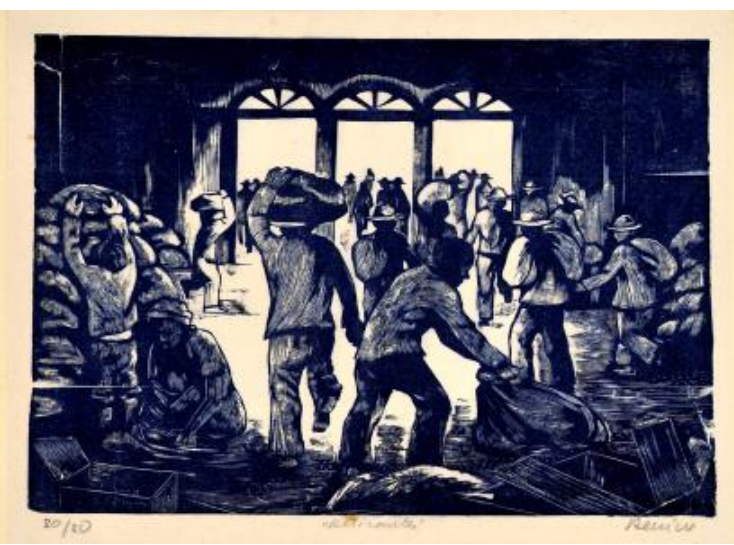

Figura 42 - Renina Katz, Retirantes, 1948-1956, xilogravura, Fundação Armando Álvares Penteado, São Paulo, 15,8 x 28,7 cm.

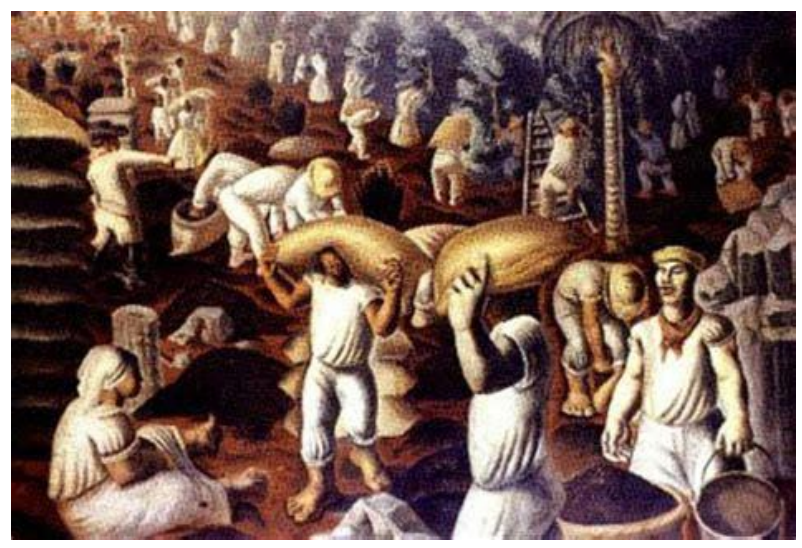

Figura 43 - Cândido Portinari, Café, 1935, óleo sobre tela, Acervo do Museu Nacional de Belas Artes, Rio de Janeiro, $1,30 \mathrm{~cm} \times 1,95 \mathrm{~cm}$.

$\mathrm{Na}$ série Retirantes, destaco as cenas de pedintes, mulheres e crianças com mãos estendidas, dependendo da bondade alheia. Nesta gravura, foi utilizada a cor ocre para a sua impressão. Aqui é possível tecermos correlações entre as figuras de Renina Katz e as de Käthe Kollwitz (ver figuras 10 e 46). As semelhanças são vistas nos rostos das figuras de mulheres e crianças, nas linhas que determinam suas expressões, os cabelos e na situação dramática da maternidade e da infância impotentes frente à situação vivida. O realismo social predomina nessas composições. Essa gravura foi elaborada em cor ocre, o que reforça ainda mais o seu caráter de denúncia, liga a composição às coisas terrenas, existenciais da vida humana. 


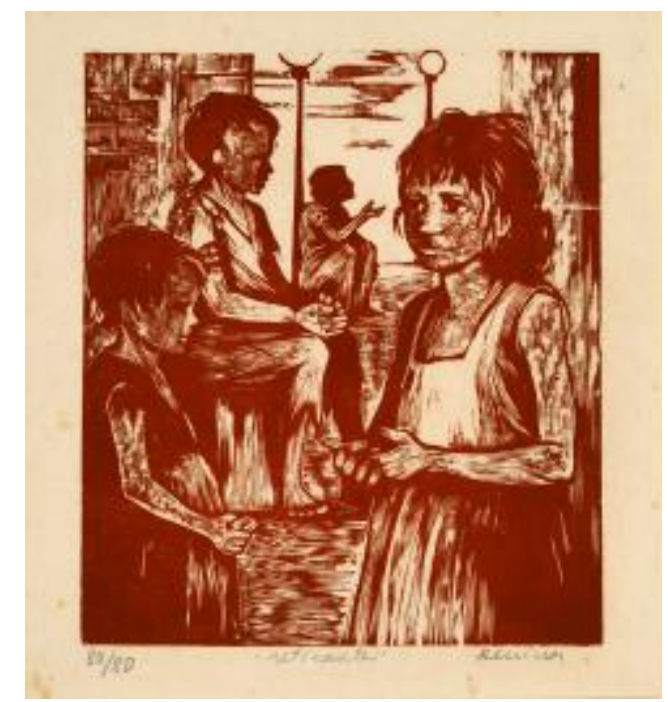

Figura 44 - Renina Katz, Retirantes, 1948-1956, xilogravura, Fundação Armando Álvares Penteado, São Paulo, $19,2 \times 17,8 \mathrm{~cm}$.

Nessa série, é frequente encontrarmos também imagens de crianças, junto às de mulheres. Um menino porta um cipó em mão e abre caminho para três mulheres em caminhada pelos matos. A gravura é estruturada na diagonal e nela há um burro com jacá e outra criança no lombo do animal. Lembra uma cena interiorana brasileira. Todos têm vestimentas simples, encontram-se descalços e as mulheres levam pano nas suas cabeças. A cor utilizada para a impressão foi o ocre bem próximo aos tons terrosos.

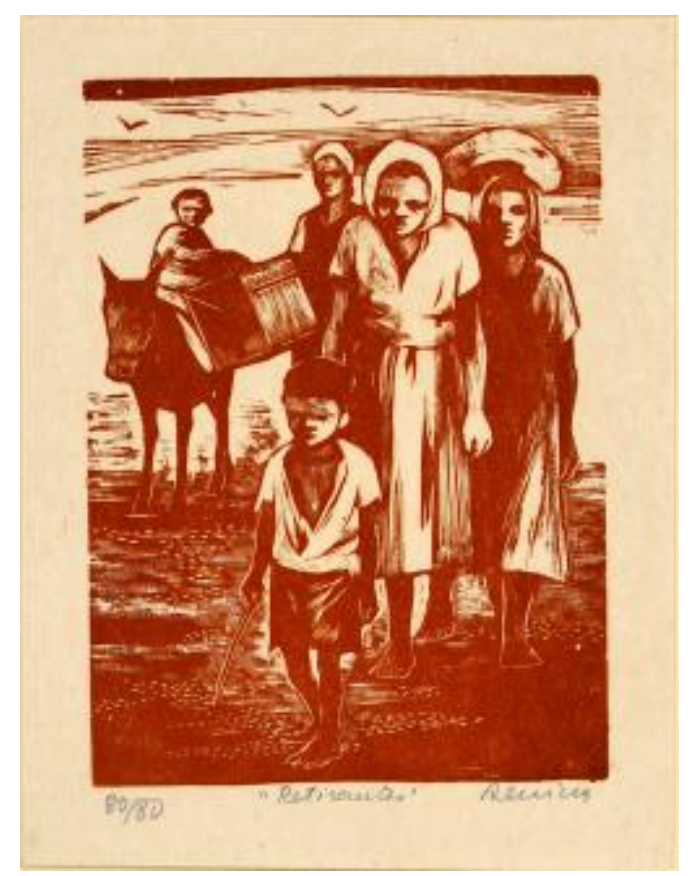

Figura 45 - Renina Katz, Retirantes, 1948-1956, xilogravura, Fundação Armando Álvares Penteado, São Paulo, $17,4 \times 13,2 \mathrm{~cm}$. 
As gravuras nas quais podemos verificar mais detalhes nos rostos das figuras são as da série Retirantes. Nelas verificarmos o olhar dos personagens, suas expressões fisionômicas traçadas com vários tipos de hachuras. Os planos dessa gravura são construídos com elementos do imaginário nacional, como cestas, chapéus e casas de palha e taipa, cactos, redes, estações rodoviárias, e raras cenas no espaço urbano. As cenas nos espaços urbanos, quando surgem, são de estações, locais de chegadas dos retirantes e, às vezes, podemos observar também a presença de cenas em cantos de ruas.

Em Retirantes, olhares são surpreendidos e estão presentes em seus personagens. É possível flagrarmos crianças surpresas e nos olhando diretamente. Este olhar está impregnado de angústia e incerteza que vem do expressionismo. É na série de Retirantes que Katz retrata com precisão a riqueza dos detalhes presentes nas cenas impregnadas de ação. Existe a presença de uma diversidade de tramas construídas pelas mais diversificadas linhas imaginárias e suas texturas. Esta gravura foi impressa em vinho, cor quente que intensifica a cena e a impregna de emoção. Na série "Retirantes", há uma gravura com uma mulher inerte e recuada à parede. Ela tem o corpo encoberto por uma manta, ao seu lado encontra-se uma criança e uma bacia para a coleta de donativos. Ao fundo, há um paredão desgastado que nos revela a precariedade. Nestas gravuras, também está presente a influência que os trabalhos de Käthe Kollwitz exerceram sobre a produção das obras que compõem a Antologia Gráfica. Nas gravuras sobre os retirantes, há também o predomínio do expressionismo em suas composições e podemos observar a inspiração de Katz sobre a obra de Käthe Kollwitz.

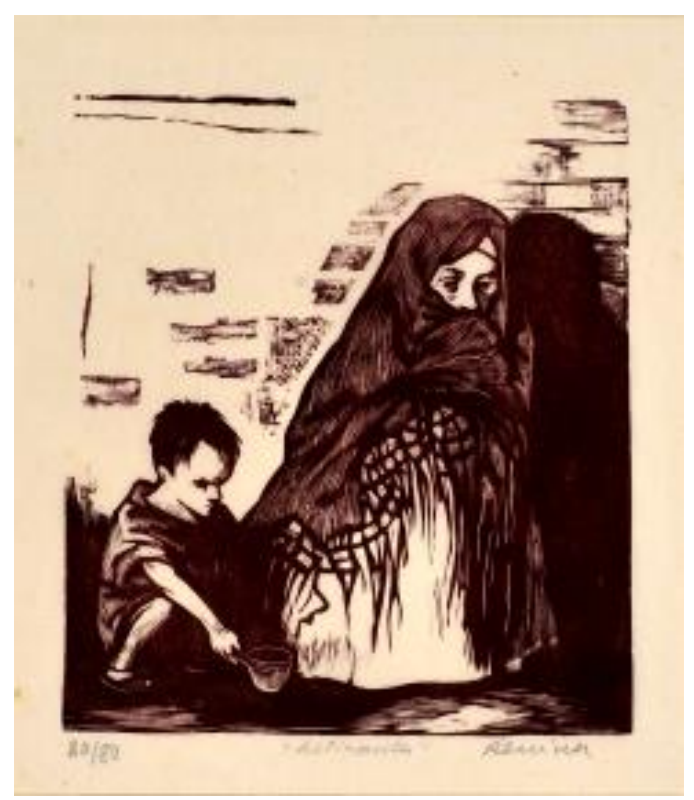

Figura 46 - Renina Katz, Retirantes, 1948-1956, xilogravura, Fundação Armando Álvares Penteado, São Paulo, $18,2 \times 15,9 \mathrm{~cm}$ 


\subsection{A série de gravuras Favela}

As gravuras que compõem a série Favela retratam sobre a realidade social das mulheres trabalhadoras, faveladas e provedoras de suas famílias. As linhas que definem as suas imagens são muitas e utilizadas em diversas direções criando um aspecto sujo e desordenado as suas figuras, demonstrando assim uma desorganização espacial que predomina nas construções e caminhos na favela. Essas gravuras nos mostram a geometria da precariedade das favelas brasileiras. Os únicos elementos humanizados são os dois coqueiros, a mulher e o homem em caminhos tortuosos adentrando esse vasto mundo que se forma como única alternativa a ser vivida nas grandes cidades.

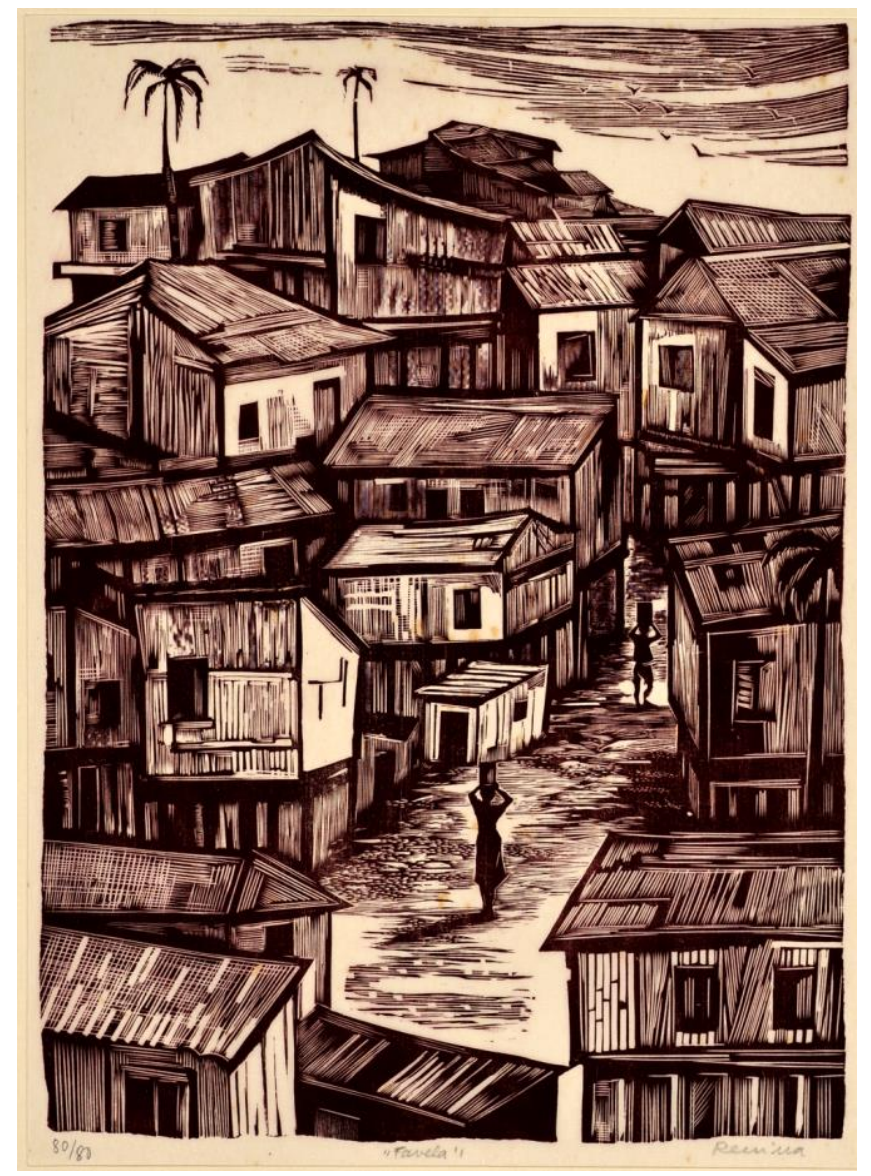

Figura 47 - Renina Katz, Favela, 1948-1956, xilogravura, Fundação Armando Álvares Penteado, São Paulo, 34,8 $\mathrm{x} 25,3 \mathrm{~cm}$.

As gravuras da série Favela foram elaboradas em 1956 e impressas em várias cores, indo do marrom, verde até o preto. Apresentam cenas com mulheres, crianças e alguns animais ambientados em suas rotinas diárias na favela, tais como carregando lata d'água na cabeça, 
lavando roupas em bacias, cuidando das crianças e dos animais, separando alimentos e interagindo com outras mulheres - todas em suas atividades intensas são ricas em movimento.

A construção da imagem da mulher de Renina Katz neste álbum é de intensa simplicidade e elegância, dadas pela dignidade do uso da linha e das formas e carregadas de humanidade. As suas vestimentas são simples, construídas por linhas de delicadeza incomensuráveis. Nesta série, a artista utiliza para a sua construção uma menor quantidade de planos. É frequente a construção com apenas dois ou três planos. Raramente utiliza nelas quatro planos, mas quando o faz são planos simples que surgem a partir de uma figura central, localizadas no primeiro plano.

As linhas que definem essa série são mais soltas, delicadamente mais finas, trabalhadas exaustivamente em busca da perfeição. Segundo Nélida Piñon (1977), Renina Katz encontravase inclinada ao rigor técnico e exaustivo. São muitas as gravuras que compõe. Um verdadeiro exemplo de disciplina intensa na construção do espaço estrutural. Entre essas gravuras, há uma em verde militar que figura mulheres transportando feixes delicados de madeira nos braços e/ou cabeças, inclusive há a presença de crianças nesta atividade. O espaço em volta das figuras humanas, ao fundo e ao alto, predomina com imagens de casas da favela. Observamos nesta composição uma riqueza infinita de linhas e hachuras que definem muitas texturas e criam o claro-escuro de Renina Katz. Nesta gravura, o nosso olhar é guiado a procurar o rosto dos personagens que a compõem. Percebemos a partir daí, que não há expressão facial nelas, continuamos pelas demais gravuras da mesma série e sentimos falta do olhar de seus personagens. Podemos concluir que a artista optou por ocultar olhares e expressões faciais nessa série. Continuamos a observação das demais gravuras de título semelhante e logo percebemos que em nenhuma delas sobre favela existe a construção do olhar de suas figuras. 


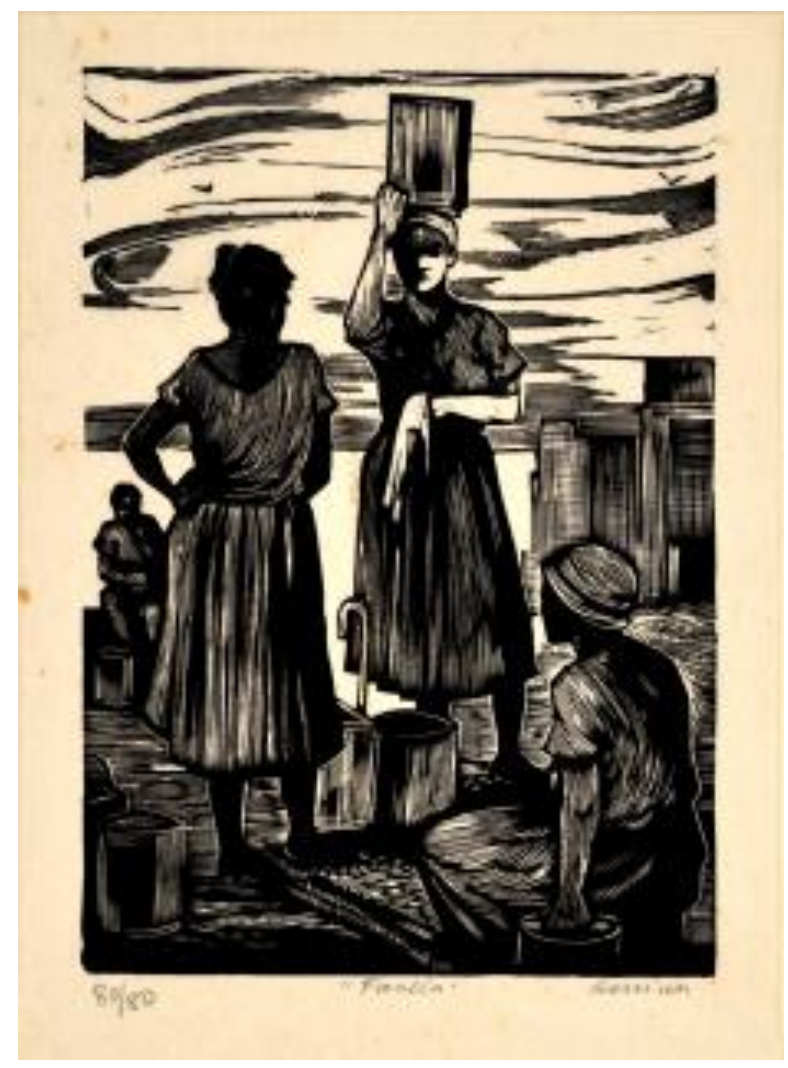

Figura 48 - Renina Katz, Favela, 1948-1956, xilogravura, Fundação Armando Álvares Penteado, São Paulo, 23,3 x $16,6 \mathrm{~cm}$.

Diferentemente de Renina Katz, Tarsila do Amaral também criou em sua imagética favela. As favelas da artista plástica são cheias de vida, bichos, gente, bandeiras, plantas em intensas cores comuns a arte popular brasileira. Após a visita da artista à Moscou em 1930, pode ser vista em sua produção aspectos do realismo socialista (ADES, 1997 p. 134).

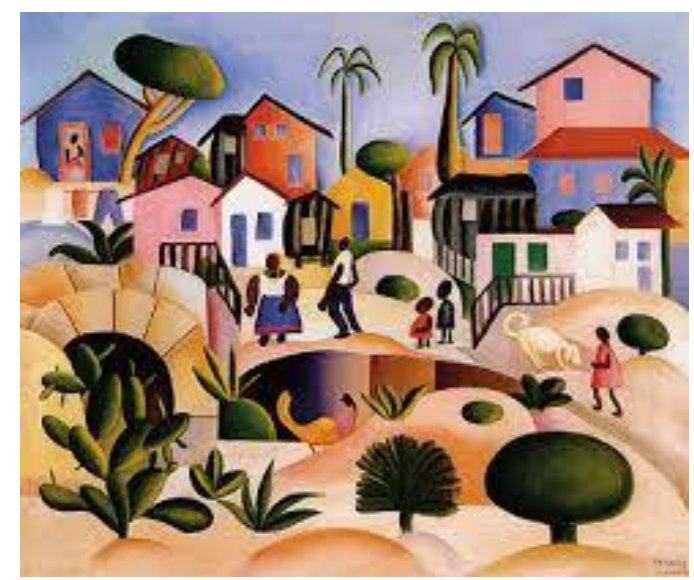

Figura 49 - Tarsila do Amaral, Morro da favela, 1924, óleo sobre tela, Coleção Hecilda e Sérgio Fadel, Rio de Janeiro, $64 \times 74 \mathrm{~cm}$. 
De outra maneira, Katz, ao construir as gravuras sobre favela, deixou predominar em sua estrutura aspectos realistas da cena, mulheres trabalhadoras em intenso movimento, articuladas com o ambiente caótico do qual fazem parte. Em Favela, a artista nos mostra como a imagem da mulher está viva e ativa numa sociedade dividida.

Ao observarmos o álbum como um todo, temos a sensação de nos impregnarmos do estilo e do realismo que a obra representa. Surge uma mistura de prazer e lamento.

\subsection{Considerações gerais e diálogos entre outras obras e as gravuras da Antologia Gráfica}

Quando voltamos o nosso olhar para as gravuras de Katz sobre os temas do trabalho do campo e outras, observamos que as suas construções ocorrem como as de Cândido Portinari através das suas representações sociais. Podemos verificar também algumas relações estruturais e temáticas entre as obras desses artistas com as gravuras de Katz sobre Favela, Retirantes e outras que possuem um aspecto lírico, como podemos verificar através das seguintes obras de Portinari: Marias, A família, Mulher e Criança, Lavrador, Café, Mulher com crianças, Meninos na Gangorra, Retirantes e Mulher Grávida. Katz e Portinari estão olhando para homens, mulheres e crianças descalças, com calças dobradas ao meio das pernas, com muitos chapéus, corpos volumosos e portando seus instrumentos de trabalho, como pás, carrinhos de mão transportando objetos pesados em ombros ou cabeças, cestas com peixes, tudo revela a interação do homem com as suas atividades.

Os corpos encontram-se sempre em ação, ou prestes a agir. Na maior parte das vezes, constroem os seus planos de forma lineares e em planos que penetram o seu suporte ao seu modo e em sua linguagem. Nas gravuras de Antologia Gráfica, Katz as compõe em vários planos com a imagem principal à frente e são acrescidos posteriormente os demais elementos dos cenários que são recorrentes, os campos, as matas, os céus, as pedras, os mares e pouquíssimos horizontes com suas nuvens e pássaros.

As gravuras em estudo, em sua maior parte, são estruturadas na horizontalidade. Poucas foram construídas na vertical. Esse fato nos faz lembrar a afirmação da artista por ocasião de sua entrevista em Contraponto em 2003, quando o entrevistador teria se referido ao seu estilo e não a um idioma de Renina Katz. Afirmara que ela trabalha na horizontalidade e não na verticalidade. Segundo Katz, a arte japonesa e a chinesa trabalham na vertical, pois a arte oriental vê o mundo através da porta. Enquanto os ocidentais, como Durer e Leonardo, o veem através da janela. Segundo a artista, ela se inclui entre os que apreciam olhar pela janela. 
Katz acredita que o trabalho do artista só começa a ser reconhecido quando ele trabalha muito e consegue criar, dentro de um repertório cultural que acumulou em seu percurso, algo particular, através de uma linguagem pessoal e desenvolvida por um trabalho incessante de construção da sua própria voz.

Gravuras figurativas do realismo social dos anos 50 de autoria de Renina Katz, Camponesas e Retirantes, dialogam com outras gravuras de vários artistas modernos brasileiros, tais como Lívio Abramo, Danúbio Gonçalves, Glênio Bianchetti com Pequena Olaria (linoleogravura de 1951) e Feira de 1952, gravuras com muito movimento, e figuras mais volumosas. Outras gravuras, como as de Wellington Virgolino, estabelecem uma articulação através de suas gravuras compostas por linhas longas que cortam o suporte de 1953, Cortador de Cana e Xangô de 1954. Renina Katz mostra com as suas linhas de vários tipos, circulares e longas, finas e grossas, que definem os chapéus e os corpos que dialogam com as linhas das vestimentas de Wellington Virgolino na gravura Xangô. As gravuras Negra, Operário e Figura, todas de Lívio Abramo dos anos de 1951, 1933 e 1938 respectivamente, proporcionam uma relação próxima entre as demais gravuras.

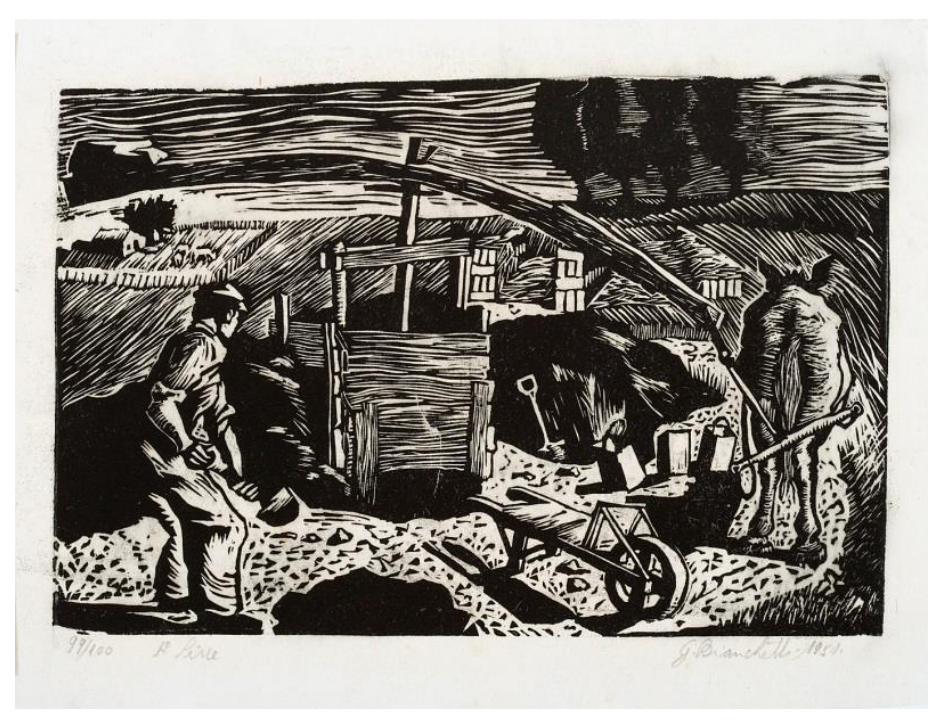

Figura 50 - Glênio Bianchetti, Pequena Olaria, linoleogravura de 1951, Itaú Cultural, $23,80 \times 32,30 \mathrm{~cm}$.

As gravuras de Katz estabelecem com reciprocidade um intenso diálogo com pinturas em óleo sobre tela de artistas como Mário Zanine, Olaria de 1942, Paisagem com figuras em pé de Flávio Pennacchi, Cândido Portinari e Clovis Graciano com as suas obras de mesmo nome, Família de 1935 e de 1947 respectivamente. Não poderia deixar de comentar sobre as mulheres retratadas por Di Cavalcanti, as suas belas mulatas sensuais ambientadas pelo seu meio social. Elas dialogam com outras cenas de mulatas de 1941 e Moças de São João del Rei 
de 1945 de José Pancetti. De Carlos Prado, precisamos lembrar-nos de Batuque de 1935, obra na qual predomina o intenso movimento dos corpos e as suas formas volumosas e macias.

As gravuras de Katz e as demais obras se envolvem por uma vontade de compor o nacional. A estrutura básica para a sua construção se apoia na figura do tipo brasileiro que sofre. As gravuras nos mostram cenas com figuras de mulheres e crianças, famílias e muitos trabalhadores do campo. Desde a criação da Academia Imperial de Belas Artes no Rio de Janeiro em 1826, já havia uma necessidade de definir os pressupostos para a arte brasileira. Esta foi uma preocupação presente no campo cultural. Um destes pressupostos era de que a arte nacional deveria representar a história do país e deveria ter como princípio norteador os padrões de beleza e ensinamentos de origem europeia, o único conhecido na época. Surge, assim, a riqueza natural e exótica das paisagens que predominaram na época.

O debate no país sobre a identidade nacional na arte continuou durante uma boa parte do século XX. Os nossos artistas modernos e alguns críticos literários acreditavam que encontrariam a solução retomando o aspecto da diversidade cultural. Logo, a figura do mestiço substitui a do índio e cenas de trabalhadores em suas atividades braçais se expandiram no imaginário coletivo e nas diversas linguagens. A seleção das obras e a lembrança dos artistas citados nos aproximam desde debate.

Logo, percebemos também que as gravuras de Renina Katz dos anos 50 possuem essas preocupações e, a partir delas, a artista descreve o seu olhar sobre o nacional. Não restam dúvidas sobre a sensibilidade presente através da dor humana, que é intensa em Antologia Gráfica. Por isso, surgiu esta rotulação de artista social tão frequentemente encontrada em sua biografia.

Katz fez muito mais pela história da arte brasileira com o seu realismo, característica marcante na obra em estudo. Ela realizou diferentes procedimentos gráficos originais, dominou a técnica e teve uma produção vasta em sua carreira. Sem dúvidas, ela contribuiu para a valorização da artista mulher no século XX no Brasil. Nas gravuras de Antologia Gráfica, Renina Katz mostra as suas qualidades como artista consciente e como humanista. 


\section{CONCLUSÃO}

A gravura foi utilizada por muito tempo como um trabalho artesanal e atendeu a várias utilidades, desde impressão de moedas, de cartas de baralho e, principalmente, das atividades gráficas.

A gravura brasileira, assim como a alemã e a mexicana, foram utilizadas por um longo período como expressão artística e como símbolo de luta de classes através de uma arte de denúncia. Essa expressão artística esteve intimamente relacionada à situação política e social decorrente da Revolução Russa em 1917, movimento que reverberou em vários países, inclusive no Brasil.

Historiadores, estudiosos e críticos de arte envolvidos com o socialismo brasileiro atribuíram a Renina Katz, pelo seu envolvimento com os projetos da esquerda, o status de artista social. Dado o caráter engajado de parte considerável de sua produção, principalmente as gravuras de Antologia Gráfica, não se trata de uma situação completamente indevida. Entretanto, não a representa em sua totalidade e, pela diversidade de sua obra, seria restringi-la a apenas um único período da sua produção. Katz teve uma produção mais abrangente: além da arte social, produziu gravuras com temas mais livres e poéticas, algumas das quais, inclusive, estão em Antologia Gráfica.

No Brasil e na América Latina, podemos verificar as lutas de classe acompanhadas pelos artistas através de suas produções artísticas. No México, a gravura contribuiu com a divulgação dos ideais socialistas por meio do trabalho dos artistas revolucionários que, além de interferirem positivamente em suas conquistas sociais, influenciaram também os europeus e os demais latino-americanos.

A figuração na União Soviética atendeu, acima de tudo, a uma estratégia política de mover opiniões. No Brasil, ela ficou atrelada a uma tentativa de mudanças sociais se apoiando nas produções artísticas e marcando um período na história da gravura modernista. A gravura modernista de Katz certamente contribuiu com os debates sobre a estética revolucionária e das diretrizes partidárias nos anos de 1940 e 1950 e como podemos ver, o seu trabalho demonstra um envolvimento político.

A artista, em suas entrevistas, revela um perfil aberto e mostra-se sempre disposta a novos desafios, características essas que a permitiram transitar por várias fases sem perder de vista o seu suporte e a habilidade técnica. Encontra-se atenta às tendências e às suas próprias experiências artísticas, ora com a cor, ora com a técnica, com os temas e, sobretudo, com a disciplina, que é uma constante em sua trajetória. 
A sua ligação com a existência humana a impede de vagar em seu processo criativo e a situa na realidade da vida, mesmo na abstração através da litografia, como em Cárceres, Vermelho e Negro, Transfiguração, Territórios Imaginários e outras. Essas séries nos mostram como Katz se dispõe a rever o seu processo criativo constantemente, incorporando ou retirando elementos que fazem toda a diferença em suas composições.

É indiscutível a contribuição da obra Antologia Gráfica para a história da gravura brasileira. Ela representa, através de suas gravuras, um momento muito rico no debate sobre a necessidade de uma mensagem através da produção artística. Essa necessidade de revisão sobre o propósito da arte foi estimulada pela revista francesa Commune, mas chegou tardiamente até nossos artistas, principalmente entre os modernistas. Antologia Gráfica é o registro nacional desse apelo em volta da arte em momento conturbado do pós-guerra.

Em Antologia Gráfica, a artista utilizou suas goivas e narrou histórias de um Brasil injusto, sofrido politicamente, socialmente e economicamente. Estas narrativas são denúncias resultantes de um trabalho minucioso, repleto de beleza e rico em detalhes. Todas as imagens são traçadas por linhas dramáticas e decisivas, fortemente registradas na madeira e impressas em forma de gravuras que ganhariam visibilidade através de uma evocação heroica da sobrevivência e sabedoria da gente que se desloca de seus mundos árduos em busca de sonhos em cidades em desenvolvimento nos anos de 1940 a 1950.

Antologia Gráfica representa uma seleção de gravuras da artista e foi marcada pela sua criatividade, capacidade de observação, desenho e processo de gravação. Nesse trabalho árduo, é possível perceber a humanidade e a sensibilidade presentes nas imagens. É uma verdadeira demonstração do domínio técnico e espontaneidade em relatar sobre a vida do homem inserido à natureza que o rodeia e ao seu meio social e político (BITTENCOURT, 2008, p. 7-11).

Nas décadas de 1940 e 1950, Kollwitz se torna uma referência importante do realismo socialista brasileiro, tendência estética criada na União Soviética e difundida pelo Partido Comunista, tendo seus trabalhos publicados em revistas como Fundamentos, Horizonte e pelos Clubes de Gravuras, principalmente o de Porto Alegre, que foi conduzido por Carlos Scliar e é considerado um ponto fundamental para a propagação dos ideais comunistas na arte.

Em Antologia Gráfica podemos visualizar, através das suas gravuras, essa inspiração de Katz sobre a obra de Käthe Kollwitz. Principalmente, quando as gravuras se referem aos temas relacionados aos dramas existenciais e às situações políticas e econômicas de homens e mulheres trabalhadores e crianças, todos ambientados tanto no campo, nas grandes cidades e principalmente através das gravuras sobre os deslocamentos migratórios. 
Lembramo-nos das produções de Portinari quando as gravuras de Katz se relacionam com a força de trabalho no campo envolvendo mulheres ou homens. Nas séries Camponesas, Camponeses, Trabalhadores e outras que Katz nos faz lembrar as produções artísticas de Cândido Portinari, em que a figura do homem e da mulher trabalhadora são retratadas como elementos nacionais. Podemos ver também, nas gravuras Camponesas, a influência do realismo francês.

Na série Favela, a beleza das formas que define as suas imagens sobressae sobre a questão social e as gravuras se desviam da realidade cruel da ausência das mínimas condições sociais. Essa série lembra as gravuras japonesas, nas quais predominam na sua construção um bloco no meio da gravura em que podemos ver as imagens flutuando no centro do suporte. As construções sobre favela foram muito delicadas e as imagens atingiram um nível de beleza que não correspondia com a realidade, o que causou um esvaziamento no discurso de Katz. A beleza revelada em Favela passou a funcionar como um aspecto atenuante da pobreza.

O figurativismo de Renina Katz tem intensa conotação social e enobrece a condição operária através do seu ativismo que permanece presente através das diversas técnicas utilizadas, mas sempre presente nas relações com as artes e em suas atividades como docente.

Em Antologia Gráfica encontramos a humanidade nas gravuras de todas as séries presentes na obra. Ela surge da militância que predominava na época sobre a produção da artista. As gravuras estão repletas de sentimentos, mas apenas algumas são capazes de provocálos. Nessas gravuras está presente uma preocupação exacerbada com a habilidade e com a disciplina necessárias para o desenvolvimento dos aspectos estéticos visuais da gravura.

Entre as séries de Antologia Gráfica, podemos encontrar algumas gravuras com títulos bem específicos e que foram construídas por linhas mais soltas, despretensiosas, sem tensão, parecem ter sua composição livre das preocupações sociais. Talvez uma manifestação que já aponta para uma predominância da abstração e para a saída do figurativo. 


\section{REFERÊNCIAS BIBLIOGRÁFICAS \\ DOSSIÊS PRESENTES EM INSTITUIÇÕES}

Dossiê da artista do Centro de Pesquisa do Museu de Arte de São Paulo Assis Chateaubriand - MASP.

Dossiê da artista do Centro de Documentação e Memória da Pinacoteca de São Paulo CEDOC.

Dossiê da artista na Biblioteca do Itaú Cultural - Avenida Paulista.

Dossiê da artista da Fundação Armando Alvares Penteado - Museu de Arte Brasileira, São Paulo, SP-MAB/FAAP.

\section{LIVROS, ARTIGOS E CATÁLOGOS}

ADES, Dawn/Contribuição: Guy Brett, Stanton Loomis Catlin e Rosemary O'Neill, Arte na América Latina: a era moderna, 1820-1980. São Paulo, 1997.

AMARAL, Aracy. Arte para quê? A preocupação social na arte brasileira 1930-1970: subsídios para uma história social da arte no Brasil. $3^{\text {a }}$ Edição. São Paulo: Studio Nobel, 2003.

BITTENCOURT, Elaine. Renina Katz. $1^{\text {a }}$ Edição. São Paulo: Lazuli e Companhia Editora Nacional, 2008.

CARY, E. A gravura chinesa. Horizonte, n. 6, fev.-mar. 1951, p. 76-78.

COLI, Jorge. Autoritarismo moderno e renovação crítica. Como estudar a arte brasileira do século XIX? São Paulo: SENAC, 2007, p. 9- 22

COSTELLA, Antônio. Introdução à Gravura e História da Xilografia. Campos do Jordão: Editora Mantiqueira, 1984.

DUPRAT, Andréia C. D. A repercussão de Käthe Kollwitz (1867-1945) como modelo de artista social no Brasil, Universidade Federal do Rio Grande do Sul, s/d. Disponível em: <http://www.cbha.art.br/coloquios/2016/anais/pdfs/4_andreia\%20duprat.pdf>.

ESTAÇÃO PINACOTECA. Gravura e Modernidade. Gravura Brasileira dos anos de 1920 aos anos de 1960 no acervo da Pinacoteca de São Paulo. Gabinete de Gravura Guita e José Mindlin, 2014-2016.

FABRIS, Annateresa. Portinari e a arte social. Estudos Ibero-Americanos. Pontifícia Universidade Católica do Rio Grande do Sul, v XXXI, n 2., p. 79-103, dezembro de 2005.

FERNANDES, Ana Cândida F. de Avelar. Artistas Plásticos no Suplemento Literário de O Estado de S. Paulo. Dissertação de Mestrado, Universidade de São Paulo, São Paulo, 2007. 
GOMBRICH, E.H. A história da arte; tradução Álvaro Cabral. Rio de Janeiro: LTC - Livros Técnicos e Científicos Editora Ltda., 2012

KATZ, Renina. Renina Katz. Artistas da USP. Volume 6. São Paulo: Editora da Universidade de São Paulo, 1997.

. Renina Katz. Doação da Artista ao Museu Nacional de Belas Artes. Caixa Econômica Federal: Brasil, 2007-2008.

. Renina Katz. Coleção Cadernos de Desenhos. Organizadora: Lygia Eluf.

Editora da Unicamp, Imprensa Oficial do Estado de São Paulo: São Paulo, 2011.

SCHAPIRO, Meyer. Impressionismo: reflexões e percepções. São Paulo: Cosac \& Naify, 2002.

SIMONE, Eliana de Sá P. de. Käthe Kollwitz. São Paulo: Editora da Universidade de São Paulo, 2004.

\section{JORNAIS}

BECCARI, Vera D’Horta. In Renina Katz. O Estado de São Paulo, 1981, São Paulo.

CRUZ, Angela. In Romanceiros da Inconfidência. Jornal da Bahia,1982. Salvador, Bahia. Sem página.

MARTÍ, Silas. Gravurista Renina Katz expõe "vísceras”, Folha de São Paulo, 31 de maio de 2008.

MAURÍCIO, Jayme. In Hoje, Renina. Rio de Janeiro, 1975. Sem página.

RIBEIRO, Leo Gilson, Renina Katz. Revista de Bordo Varig, s/d. p. 9-10. Textos curatoriais da exposição: TARSILA POPULAR, MASP, 2019. 